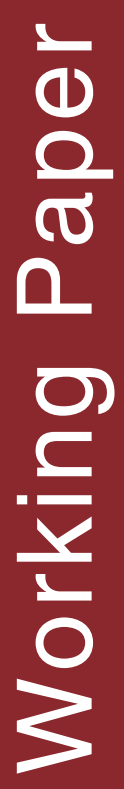

Evelyne Kiptot, Steven Franzel, Judith Sinja and Eddah Nang'ole
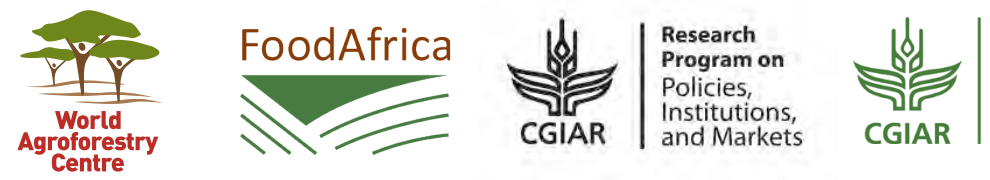

RESEARCH

Forests, Trees and

Agroforestry

$\overbrace{\text { INTERATIONAL }}^{\text {HEIFER }}$ 


\section{Preferences and adoption of livestock feed practices among farmers in dairy management groups in Kenya}

Evelyne Kiptot, Steven Franzel, Judith Sinja and Eddah Nang'ole 


\section{LIMITED CIRCULATION}

Correct citation: Kiptot E, Franzel S, Sinja J, Nang'ole E. 2015. Preference and adoption of livestock feed practices among farmers in dairy management groups in Kenya. ICRAF Working Paper No. 208. Nairobi, World Agroforestry Centre. DOI: http://dx.doi.org/10.5716/WP15675.PDF

Titles in the Working Paper Series aim to disseminate interim results on agroforestry research and practices and stimulate feedback from the scientific community. Other publication series from the World Agroforestry Centre include: Technical Manuals, Occasional Papers and the Trees for Change Series.

Published by the World Agroforestry Centre

United Nations Avenue

PO Box 30677, GPO 00100

Nairobi, Kenya

Tel: +254(0)20 722 4000, via USA +1 6508336645

Fax: +254(0)20 722 4001, via USA +1 6508336646

Email: worldagroforestry@cgiar.org

Website: www.worldagroforestry.org

CWorld Agroforestry Centre

Working Paper No 208

The views expressed in this publication are those of the authors and not necessarily those of the World Agroforestry Centre.

Articles appearing in the Working Paper Series may be quoted or reproduced without charge, provided their source is acknowledged. 


\begin{abstract}
About the authors
Evelyn Kiptot is a social scientist at the World Agroforestry Centre, Nairobi, Kenya.

Contact: ekiptot@cgiar.org
\end{abstract}

Steven Franzel is a principal agricultural economist at the World Agroforestry Centre, based in the United States of America.

Contact: s.franzel@cgiar.org

Judith Sinja is a consultant based in Nairobi, Kenya.

Contact: judithsinja@yahoo.co.uk

Eddah Nang'ole is an agricultural economist based in Nairobi, Kenya.

Contact: enangole@gmail.com 


\section{Summary}

This report presents the results of a study that assessed farmer preferences and adoption of livestock feeds and feed practices promoted by the East Africa Dairy Development (EADD) Project. The study was carried out in nine out of 21 sites where the EADD project operates. The sites are situated in central Kenya, north Rift Valley and South Rift Valley regions of Kenya. They include Kabiyet, Siongiroi, Sirikwa, Olkalou, Olenguruone, Metkei, Sot, Cherobu and Taragoon. The sample was drawn from farmers belonging to dairy management groups. Collection of data was through a formal household survey that was conducted by interviewing individual dairy farmers using a structured questionnaire. Data collected was on socioeconomic and demographic characteristics, feed practices on farm, farmer preferences and criteria used for selection, constraints faced in the production of livestock feed practices, proposed interventions and future plans.

Farmers interviewed comprised 60 percent men and 40 percent women out of the total sample of 181 dairy farmers. The farmers were middle-aged; about 44 years old with an average of about 46 years and 41 years respectively for men and women. Almost all farmers $(97 \%)$ had basic education. Overall land owned was about 13 acres with femaleheaded households owning less land than their male counterparts. The main enterprises practiced in order of importance were dairy farming, food crops (e.g. maize, beans and sweet potatoes), poultry and cash crops (e.g. tea and wheat). On average, farmers had about 13 years of experience in dairy. Livestock owned ranged from pure, cross and local breeds of cattle, goats, sheep and poultry. The majority of farmers (92\%) had cross-breed dairy cows with an average number of 3 for both male and female-headed households. Only 13.8 percent of households had pure breed dairy cattle with an average of 6 per household. A higher proportion of male-headed households (14.6\%) had pure breed adult cows compared to only 5.6 percent of female-headed households.

All dairy farmers interviewed had knowledge on the improved feed and feed practices introduced by EADD and other institutions. Almost all respondents (99.4\%) were aware of Napier grass and about three quarters were aware of Boma Rhodes. Only about 5 percent farmers were aware of Sudan grass, Molasses grass, giant setaria, serato and Guetamala grass. Among herbaceous legumes, lucerne was the most known by 74 percent of farmers compared to desmodium (42\%). Among fodder shrubs, calliandra was the most known by 36.5 percent of respondents followed by sesbania (12.7\%). Other fodder crops known by over 40 percent of dairy farmers included sweet potato vines and oats. The most known fodder crop residue was dry maize stover (42\%). Among feed practices, silage ranked highest.

Dairy farmers interviewed had multiple sources of information on livestock feeds and feed practices. Volunteer farmer trainers ranked first among the preferred sources of 
information followed by farmer field schools, Ministry of Livestock, EADD and Ministry of Agriculture. As regards uptake of feeds and feed practices, Napier grass had the highest uptake of 91.2 percent followed by Boma Rhodes (43.1\%). 33.1 percent of farmers planted fodder shrubs and 12.7 percent planted lucerne. Reasons for the uptake of various feeds and feed practices included use for livestock feeding, for supplementation, for feeding during dry spells, high nutritive content and multiple harvests. Lucerne had the highest percentage of farmers who were aware of the technology but did not take it up. Main constraints were lack of seed and high labour requirements.

Planting material for livestock feeds varied from feed to feed. Feed sources that were commonly cited by farmers included other farmers, neighbours, commercial agrovet shops and the EADD project. In relation to niches, the majority of farmers plant feed technologies in the cropland to protect from livestock. Among the livestock feeds preferred by farmers, Napier grass ranked highest followed by Boma Rhodes, dry maize stover, lucerne, oats and mineral supplementation. Napier grass is preferred because it is drought resistant, has fast growth, increases milk production and has high biomass. Some dairy farmers did not prefer certain feed practices due to the fact that some feeds are not drought resistant, require fertile soils, cause skin and throat irritation when harvesting, cause bloat in livestock, taint milk among many other reasons.

Despite the fact that farmers were aware of livestock feeds, some had not adopted them. Reasons given included unavailability of planting material, inadequate land, high cost of planting material, lack of technical knowledge, poor weather and labour intensiveness. Constraints experienced in the production and utilization of livestock feeds and feed practices included unavailability of planting material, lack of storage facilities, lack of technical knowledge, lack of machinery, among others. Proposed interventions include training, availing affordable seeds at agrovet shops, constructing proper storage and using machinery.

The study also found out that many farmers sell feeds particularly oats and Rhodes grass. Slightly less than 50 percent of dairy farmers are planning to increase feed production. This will be achieved by expanding acreage of land under feeds, acquiring loans and attending more training to gain more knowledge and skills. Motivation for increasing acreage of feeds is mainly due to the fact that there has been increased milk production, high returns from dairy, and availability of ready market for dairy products.

Findings from this study point to the fact that despite intensive promotion by the EADD project, there are high discrepancies between awareness of most livestock feed innovations and uptake. Issues of concern include lack of planting material (and if available expensive), technical knowledge and issues related to utilization. In order to increase uptake, concerted efforts need to be made by development partners in collaboration with Producer Organizations (POs) to make planting material accessible at 
the local level, undertake more training, and work closely with farmers to come up with solutions to constraints related to utilization.

Keywords: Fodder innovations, fodder adoption, planting material, livestock feeds, volunteer farmer trainers 


\section{Acknowledgements}

This study would not have been possible without the support of the FoodAfrica Program financed by the Ministry of Foreign Affairs, Finland. We are also grateful to the support of the EADD Project and two CGIAR research programmes: Policies, Institutions and Markets led by the International Food Policy Research Institute (IFPRI); and Forests, Trees and Agroforestry. Special thanks go to the enumerators who participated in this survey and Constant Kokonya for data entry. We thank all the dairy farmers who made this survey possible. This publication has not gone through IFPRI's standard peer-review procedure. The opinions expressed here belong to the authors, and do not necessarily reflect those of PIM, FTA, IFPRI, ICRAF or the CGIAR. 


\section{Table of contents}

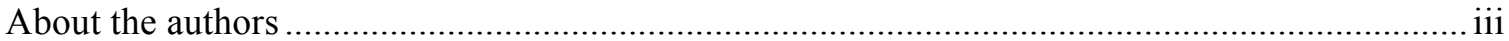

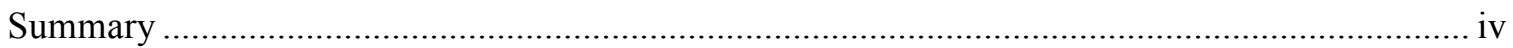

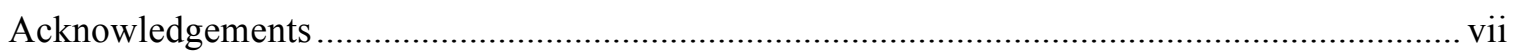

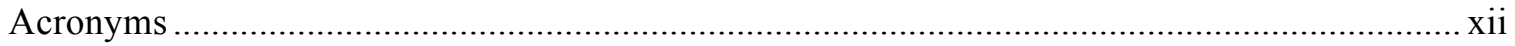

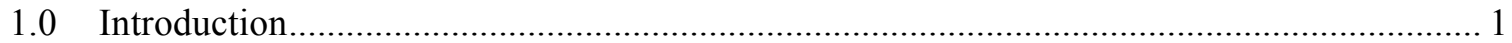

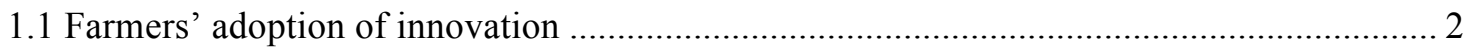

1.2 Farmer preferences of livestock feeds and feed technologies ......................................... 4

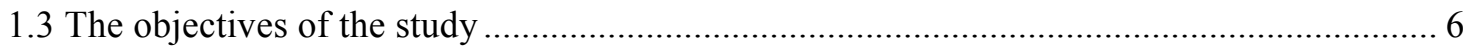

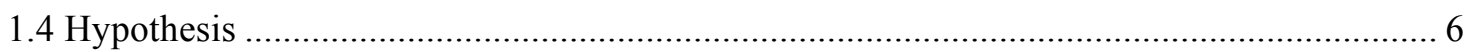

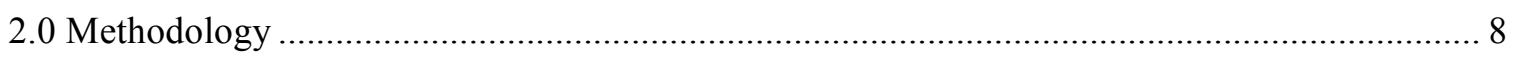

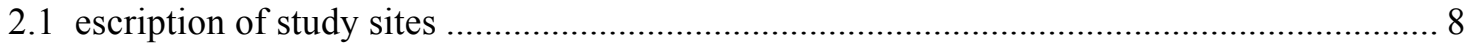

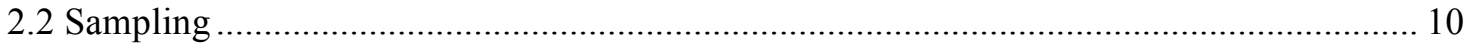

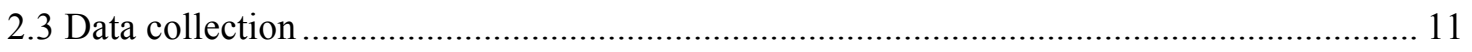

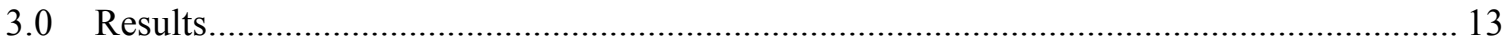

3.1 Demographic and socioeconomic characteristics of respondents …................................ 13

3.2 Experience in dairy farming and awareness of livestock feeds and practices .................... 20

3.3 Farmers' awareness of feeds and feed technologies promoted by EADD ......................... 20

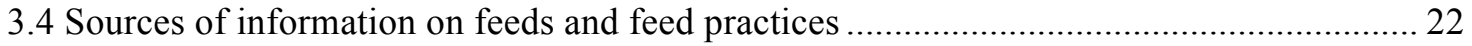

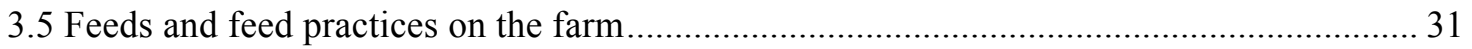

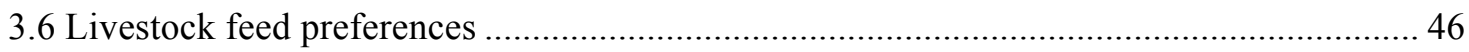

3.7 Feeds and feed practices that farmers have not taken up and reasons ..............................58

3.8 Constraints and interventions in production of feeds and feed practices ........................... 62

3.9 Constraints experienced in the utilization of feeds/feed practices...................................... 69

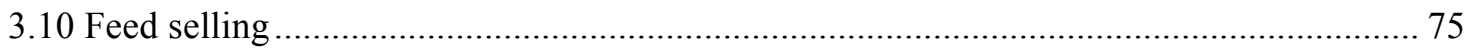

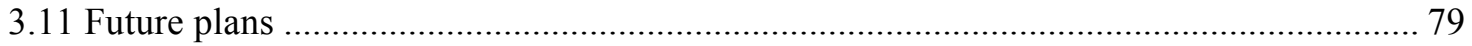

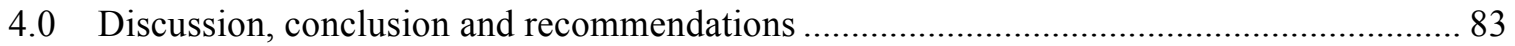

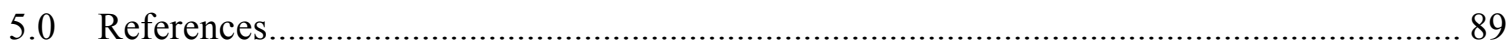




\section{List of Tables}

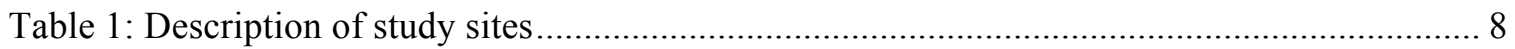

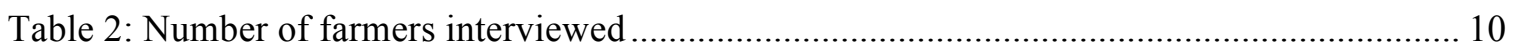

Table 3: Age, literacy levels and group membership of respondents by gender ........................ 13

Table 4: Socio-economic characteristics of households in the project sites. .................................. 14

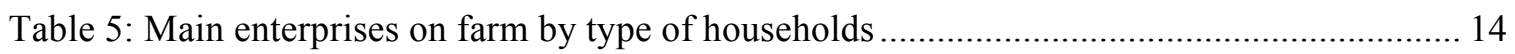

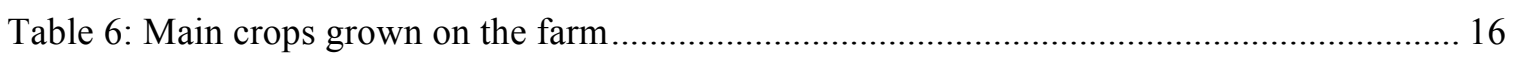

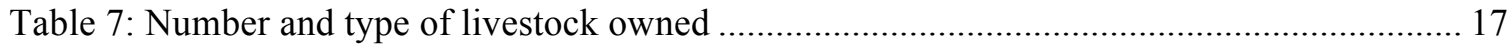

Table 8: Ownership of chaff cutter and pulverizer by type of household.................................... 19

Table 9: Ownership of chaff cutter and pulverizer by site ........................................................ 19

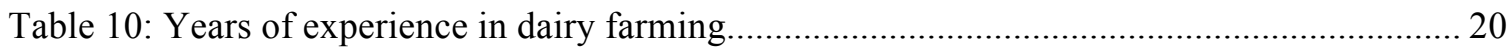

Table 11: Percentage of farmers aware of feeds/feed practices promoted by EADD project ....... 21

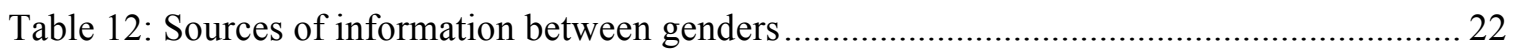

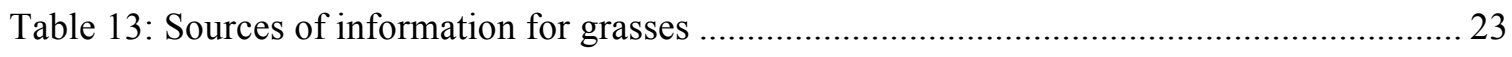

Table 14: Percentage of farmers obtaining information on herbaceous fodder legumes from

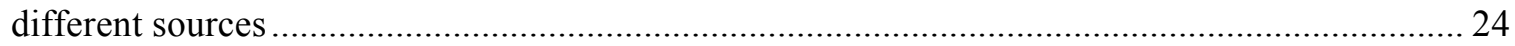

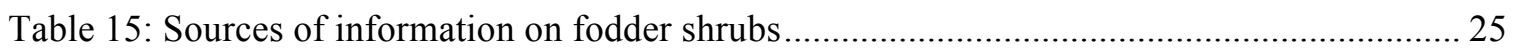

Table 16: Farmers' access to information on other fodder crops from different sources .............. 26

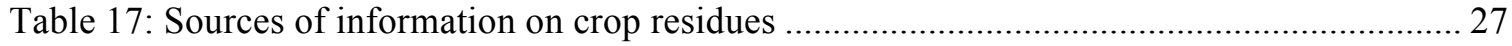

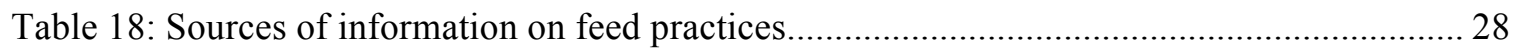

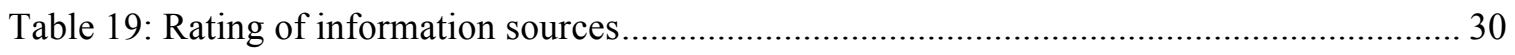

Table 20: Percentage of farmers with feed practices on farm and those aware of the technology

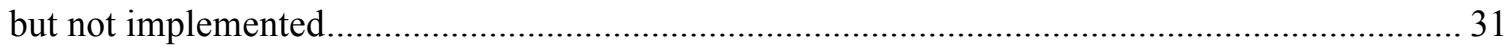

Table 21: Feeds and feed practices on the farm across gender ................................................. 33

Table 22: Percentage of farmers with feeds and feed practices on farm per PO .......................... 36

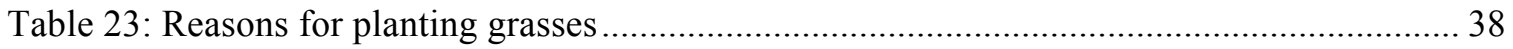

Table 24: Reasons for planting oats, forage sorghum and sweet potato vines ............................ 39

Table 25: Reasons for planting herbaceous fodder legumes and shrubs .................................... 40

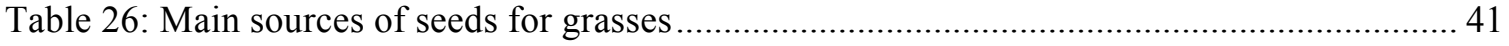

Table 27: Sources of seed/planting material for lucerne, desmodium, oats and sweet potato vines

Table 28: Sources of planting material for fodder shrubs 43 
Table 29: Niches where livestock feeds are planted

Table 30: Mean acreage of feed practices/number of trees per household

Table 31: Frequency showing number of farmers and number of trees .46

Table 32: Farmers' preferences about livestock feeds/feed practices

Table 33: Reasons why farmers prefer different types of grasses as feeds..... 48

Table 34: Reasons why farmers prefer different types of herbaceous fodder legumes, oats and forage sorghum 49

Table 35: Reasons why farmers prefer fodder shrubs. 50

Table 36: Reasons why farmers prefer crop residues 51

Table 37: Reasons why farmers prefer different types of feed practices. 52

Table 38: Reasons why farmers do not prefer certain grasses 53

Table 39: Reasons why farmers do not prefer certain herbaceous fodder legumes. 54

Table 40: Reasons why farmers do not prefer certain fodder shrubs. .55

Table 41: Reasons why some farmers do not prefer oats and forage sorghum...... 56

Table 42: Reasons why some farmers do not prefer feed formulation, hay and silage 57

Table 43: Reasons why some farmers have not adopted certain grasses 58

Table 44: Reasons why some farmers have not adopted herbaceous legumes 59

Table 45: Reasons why some farmers have not adopted fodder shrubs 60

Table 46: Reasons why some farmers have not adopted oats, forage sorghum and sweet potato vines

Table 47: Reasons why some farmers have not adopted various feed practices and crop residues

Table 48: Main constraints in producing grasses

Table 49: Proposed interventions to constraints related to the production of grasses 64

Table 50: Main constraints in producing herbaceous legumes and fodder shrubs 65

Table 51: Proposed interventions to constraints related to the production of lucerne, desmodium, fodder shrubs and oats. 65

Table 52: Constraints experienced in producing oats, sorghum and sweet potato vines 66

Table 53: Proposed interventions to constraints related to the production of oats, forage sorghum and sweet potato vines 67

Table 54: Constraints experienced in production of different feed practices 68

Table 55: Proposed interventions to constraints related to the production of feed practices. 68

Table 56: Constraints experienced in the utilization of grasses 69 
Table 57: Proposed interventions to constraints related to the utilization of grasses

Table 58: Constraints in utilization of oats, sweet potato vines, forage sorghum, desmodium and lucerne.

Table 59: Proposed interventions to constraints related to the utilization of oats, sweet potato vines, forage sorghum, desmodium and lucerne. .72

Table 60: Constraints in utilization of crop residues .73

Table 61: Proposed interventions to constraints related to the utilization of crop residues and other feed practices 74

Table 62: Number of farmers selling each feed and the average quantities ..... 76

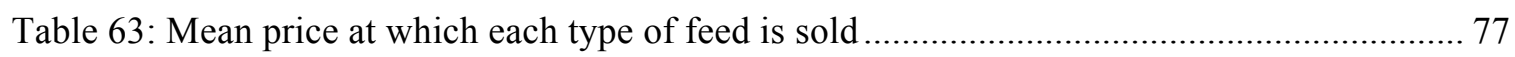

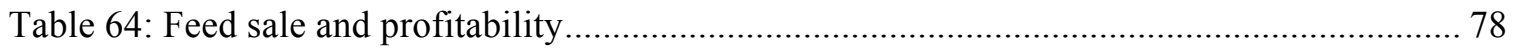

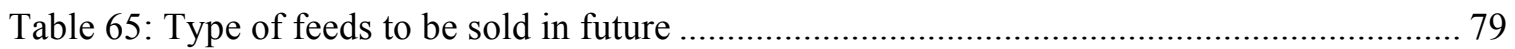

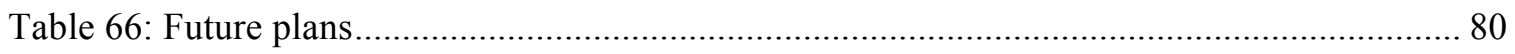

Table 67: Strategies to increase production of livestock feeds ................................................. 81

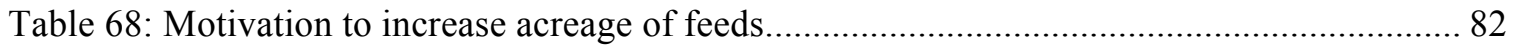

\section{List of Figures}

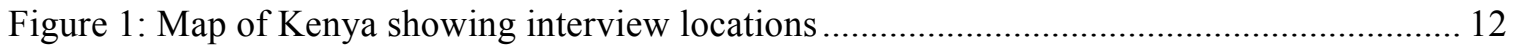

Figure 2: Percentage of farmers across sites that sold livestock feed ......................................... 75 


\section{Acronyms}

AEZ

CESPs

CGIAR

DMGs

EADD

EMPFT

FHH

FTA

IFPRI

ILRI

KARI

KES

KFA

$\mathrm{MHH}$

MOA

MOL

MPFT

NALEP

NGOs

PIM

POs

$\mathrm{UH}$

VFT
Agroecological zones

Community Extension Service Providers

Consultative Group on International Agricultural Research

Dairy Management Groups

East Africa Dairy Development Project

Exotic Multi-purpose Fodder Trees

Female-Headed Households

Forests, Trees and Agroforestry

International Food Policy Research Institute

International Livestock Research Institute

Kenya Agricultural Research Institute

Kenya Shilling

Kenya Farmer Association

Male-Headed Households

Ministry of Agriculture

Ministry of Livestock

Multi-purpose Fodder Trees

National Agriculture \& Livestock Extension Programme

Non-Governmental Organizations

Policies, Institutions and Markets

Producer Organizations

Upper Highland

Volunteer Farmer Trainer 


\subsection{Introduction}

About 870 million people were chronically undernourished in 2010, the majority living in developing countries and depending on agriculture for their livelihoods (FAO 2012a, Ahmed et al 2007). In order to meet the global demand for food, which is expected to increase by 60 percent by 2050, agricultural production must increase by $70-100$ percent. Most of this will have to come from developing countries on account of increased human populations, disposable incomes and urbanization (FAO 2011, FAO 2012b). Agricultural production has however been on the decline as a result of natural resource constraints, climate change and competing demands for land. One of the potential options to increase food security is through livestock production. Livestock production is an important economic activity that promotes and sustains people's livelihoods. It is estimated that the global demand for dairy and meat products is projected to increase by 74 percent and 58 percent respectively and a large part will emanate from developing countries (FAO 2012b, Delgado 2003)). According to FAO (2009), the global population for cattle in 2000 was 1.5 billion; it is projected to almost double by 2050 . To meet the future demand for meat and milk products, livestock productivity will need to increase significantly. Availability and access to feed resources are the two major factors that affect livestock productivity. An adequate supply of livestock feed is therefore crucial to improving the livelihoods of millions of people across the developing world. Various types of feed resources exist worldwide. They include fodder shrubs, herbaceous legumes, pasture grasses, weeds gathered from cropping areas, crop by-products and residues, agroindustrial by-products and purchased concentrates. The importance and nutritive value of these feed resources vary seasonally (Abate et al 1992).

Livestock feed production and use is driven by increases in population and income, which increase milk demand and thus the demand for feeds (FAO 2012b). In East Africa for example, increases in incomes are driving greater per capita meat and dairy consumption (World Bank 2014). In Kenya, livestock population is estimated at 17.4 million cattle with 3.3 million exotic and 14.1 million indigenous cattle, 17 million sheep and 27 million goats (KNBS 2010). This is an indicator that demand for livestock feed is high in the country due to the large number of livestock and an increase in milk and meat demand due to the high population growth (Ngigi 2005). With the present trend of rising feed prices and global inflation, livestock production has been most hit in terms of scarcity and high cost of feeds. As a result, the greatest constraint to livestock productivity in developing countries currently is the shortage of feeds and forages especially in the dry season (Ayantunde et al 2005). Farmers are unable to provide sufficient quantity and quality feeds to their livestock on a consistent basis (Hall et al 2008). The problem of feed shortage can be addressed through promotion and improvement of feed production, value addition where applicable and marketing by smallholder producers. 
The EADD Project which is a collaborative venture between Heifer International, Technoserve, African Breeders Services, International Livestock Research Centre (ILRI) and the World Agroforestry Centre (ICRAF) begun in 2008 with the objective of doubling the incomes of 179000 dairy farmers in Kenya, Uganda and Rwanda through improved dairy production and marketing. The Feeds and Feeding System Component led by ICRAF contributes to this objective through developing of producer organizationdriven site specific feed plans, and facilitating the creation of sustainable stakeholder linkages to implement the plans with the objective of increasing and sustaining milk production. The types of feed technologies already adopted by farmers include improved pastures and fodders, improvement of natural pasture, crop residue processing and utilization, pasture and fodder conservation (hay and silage making), and on-farm feed formulation (Kirui and Franzel 2011). The project currently uses a farmer-to-farmer extension approach, locally known as the volunteer farmer trainer (VFT) approach to disseminate livestock feeds and feed technologies. A total of 2520 VFTs (38\% women) have been recruited and trained since the inception of the project. They host 2309 demonstration plots for training other farmers in the use of high value feeds and improved feeding systems.

\subsection{Farmers' adoption of innovation}

Economists have defined final adoption at the farm level as the degree of use of a new technology when the farmer has full information about the new technology and its potential (Feder et al 1985). Adoption typically has been viewed from two perspectives. At the individual farm level, each household chooses whether or not to adopt and the intensity of adoption. Farm-level adoption studies, then, are concerned with the factors influencing the adoption decision either statically or dynamically by incorporating learning and experience. At a macro-level, diffusion studies examine how adoption evolves across a population or region (Feder and Umali 1993).

Scanty information exists on the adoption of feeds and feed practices in general, however there is a lot that has been documented on agriculture and agroforestry adoption. Pattanayak et al (2003) for example reviewed 120 articles on adoption of agricultural and forestry technology by smallholders and concluded that the following five categories of factors explain technology adoption which may also be applicable to livestock feeds and practices: preferences, resource endowments, market incentives, biophysical factors, and risk and uncertainty. The review notes that preferences define the objectives and motivations of the economic agents choosing technologies. Resource endowments enable their technology choices. Market incentives and biophysical factors condition the extent, timing and nature of the technology choices. Risk and uncertainty can seriously undermine investments that pay dividends only in the long run. Pattanayak et al (2003) then used this framework to perform a simple meta-analysis of 32 empirical, regressionbased analyses of agroforestry and related soil conservation investments. Although 
household preferences and resource endowments were the most common variables included in the analyses, the most significant influences on agroforestry adoption behaviour appeared to be uncertainty and risk, biophysical conditions, market incentives, and resource endowment factors. Franzel (1999) revealed that other factors such as past perception of the problem, past use of measures for addressing the problem, current practices, economic importance of the enterprise and wealth all affect the adoption potential of a technology. Pawarda et al (2010) reported that the adoption of agroforestry technologies among smallholder farmers in Zimbabwe was significantly influenced by land ownership/size, awareness, training and local institutions.

Feder et al (1985) and Feder and Umali (1993) reviewed the extensive literature on adoption and diffusion of agricultural innovations. Focusing primarily on the initial stages of the Green Revolution technology adoption and diffusion, Feder et al (1985) concluded that farm size, risk and uncertainty, human capital, labour availability, credit constraints, and tenure were the most important factors determining adoption decisions. However, the impact of farm size depends on the characteristics of the technology and institutional setting and is often a surrogate for a large number of other factors such as access to credit, risk-bearing capacity, wealth, and access to information. Since these factors differ spatially and temporally, the relationship between farm size and adoption also varies.

In 37 empirical studies of agroforestry adoption, Mercer (2004) found that more secure land tenure always had a positive impact on adoption when significant. In a comparison of tree planting between Brazil and Panama, Simmons et al (2002) found that institutional variables were more important than household preference variables; noting that tree planting in the Brazilian Amazon is 15.4 times more likely under secure land tenure. Wiersum's (1994) study of contour hedgerow adoption in east Indonesia found that the landless comprised 31 percent of the population but only 11 percent were in leucaenabased farming systems. The long term nature of agroforestry investments appears to inhibit adoption by farmers lacking secure tenure who might otherwise adopt risky innovations for short-term production goals. Thus, risk and uncertainty may be more important for agroforestry than for annual cropping decisions. Feder et al (1985) found that empirical results often differed on the relation between land tenure and adoption and were "in accordance with the unsettled debate in theoretical literature over the relation between tenancy and adoption". Feder and Umali (1993) emphasized that later stages of adoption diffusion are determined by variables such as population density; access to markets, roads, and fertilizers; and irrigation availability. However, the agro climate appears to be the most significant determinant of locational differences in adoption rates (Feder and Umali 1993). Feder and Umali (1993) also examined the literature on early adoption of soil conservation technologies, which included many agroforestry practices such as contour hedgerows. They concluded that younger, more educated, wealthier 
farmers who recognized erosion problems were more likely to adopt soil conservation technologies.

\subsection{Farmer preferences of livestock feeds and feed technologies}

Several studies have been carried out to assess availability of livestock feed resources on farms, farmer's perceptions and preferences of fodder trees. Nyaata et al (2000) assessed the use and availability of livestock feed resources on smallholder dairy farms of central Kenya. Findings indicate that Napier grass was grown by all the farms visited. Other forage crops found on the farms included Nandi setaria, sweet potato vines, desmodium and Guatemala grass. A number of pasture grasses were also observed on the contour lines in coffee fields, with ruzi grass (Brachiaria ruziziensis) being the most common. Crop residues such as maize stover, banana leaves and pseudostems were used as dry season supplements by all farmers. Other feeds reported by fewer farmers included weeds (from coffee fields and road sides), fodder tree leaves, and concentrates (mainly wheat and rice bran).

Mekoya et al (2008a) assessed farmer preferences of multipurpose fodder trees (MPFT) in the Ethiopian highlands. The study looked at preference criteria, compared farmer preference between exotic and local MPFT, and evaluated the relationship of farmers' knowledge of feed value assessment with laboratory indicators. The study used focus group discussions, and preference ranking and scoring in two districts. The comparison between exotic and local MPFT for their benefits and desired tree characteristics showed that farmers preferred local MPFT to exotics for biomass production, multi-functionality, life span, and compatibility to the cropping system. In another study, Mekoya et al (2008b) assessed the values of multipurpose fodder trees and farmers practices of growing fodder trees and the constraints they perceive for introducing and growing exotic multipurpose fodder trees (EMPFT) in the crop-livestock mixed farming system of the Ethiopian highlands. Using structured household interviews, the study assessed farmers' awareness of, perceptions about and motives to plant exotic multipurpose fodder trees and use, values and management. Findings showed that farmers were aware of the EMPFTs with development agents and farmer-to-farmer information exchange being the major sources of information. Sesbania sesban and Calliandra calothyrsus were noted to have fast growth as they could be cut 12 months after planting. The study also found out that a majority of adopters preferred exotic multipurpose fodder trees as compared to non-adopters who preferred local multipurpose fodder trees.

Roothaert and Franzel (2001) examined farmers' ranking of local fodder tree species of their choice; their criteria for assessing fodder trees; how the most preferred species rated on each criterion; species' uses, management, and ways of establishment. The study used both formal and informal surveys in three AEZs. Farmers used an indigenous board game, 'bao', to rank species. A total of 160 different local fodder trees and shrubs were 
used by farmers in the three zones. The three most preferred species in the sub-humid zone were Triumfetta tomentosa, Commiphora zimmermanii, and Bridelia micrantha. In the medium zone Aspilia mossambicensis, Lantana camara and Grewia tembensis were the most preferred while in the low zone Melia volkensii, Crotalaria goodiiformis, and $A$. mossambicensis were preferred. In the sub-humid zone, the most frequently mentioned criteria for preference of particular tree species were the ability of the fodder to satisfy hunger and contributions to animal health. Palatability and drought resistance of the tree were the most important criteria in the medium zone while effect on the condition of the animal and palatability were most important in the dry zone. Farmers' ratings on palatability for cattle and goats, and milk production for goats differed significantly among tree and shrub species.

Lukuyu et al (2011) assessed feeds and feeding practices in smallholder dairy systems. The study identified feed resources available year round in three EADD project areas. The study found that majority of farmers relied on natural pastures for feeds. Less than 30 percent of farmers practiced stall-feeding with Napier grass being the main basal feed resource. Crop residues such as green and dry maize stover, wheat straws, bean haulms, banana pseudo-stems, vegetable waste and weeds were also important livestock feed among a majority of small-scale dairy farmers. Other feed resources used on farms were Sudan grass, sorghum, Rhodes grass and fodder trees such as Leucaena spp, Sesbania spp, and Calliandra spp. Few herbaceous fodder legumes such as lucerne and desmodium were found on very few farms. The slow adoption of forage legume technologies in Africa has been attributed to lack of participatory approaches, lack of understanding of the systems, lack of recognition of farmers' perceptions as well as unfavourable policies (Thomas and Sumberg 1995, Elbasha et al 1999), among other reasons. To reduce the time lag in adoption, considerable effort is being given to understanding smallholder systems and ensuring effective farmer participation in testing, disseminating, monitoring and evaluating fodder technologies in Africa (Shelton et al 2005, Franzel et al 2003, Peters and Lascano 2003).

Since preferences are extremely difficult to measure directly, a variety of proxy variables are usually used to examine the impact of preferences on adoption. Education, age, gender, and sociocultural status are the most frequently used proxies for household preferences and were included in almost half of the studies examined by Pattanayak et al (2003). The studies conducted so far indicate that farmers' preference of livestock feeds extends beyond the scientific interpretation of biomass production potential and nutritive value. Farmers use complex criteria for evaluation of species in the frame of their multiple farm objectives (Thapa et al 1997, Roothaert and Franzel 2001, Kiptot 2007). A review of literature suggests that there is no detailed information available on uptake of livestock feeds and feeding practices used by farmers in Kenya, preference between feeds and the reasons underlying preferences. Farmers generally possess invaluable knowledge 
about local and exotic species that can be used to determine the most appropriate feeds in regions where smallholder dairy farmers are located. This study will therefore evaluate the uptake of livestock feed and feed practices promoted by the EADD project. It will examine farmers' preference of livestock feeds and practices and find out reasons that influence the choice of preferred livestock feeds and practices.

\subsection{The objectives of the study}

The overall objective was to evaluate the adoption of livestock feeds and feed practices promoted in EADD sites in Kenya and the reasons behind farmers' choices of preferred practices.

Specific objectives:

1. Identify livestock feed and feed practices grown and used by farmers.

2. Determine farmer's preferred feeds and feed practices and the criterion used for selection.

3. Among the feeds and feeding practices that the EADD project has disseminated, determine which ones the farmer knows about, which they have tried and which they are continuing or expanding. For the ones they have not tried or have tried and stopped, find out the reasons why.

4. Determine farmers' future plans and strategies related to feed and feed practices.

\subsection{Hypothesis}

The study is intended to help identify the most preferred livestock feed resources by farmers and hence it will addresses the hypotheses that:

1. All livestock farmers know about livestock feeds and feed practices; however the type and number of species vary depending on exposure (research, extension, NGOS, mass media), level of education, membership in groups, number of groups a farmer belongs to, type of feeding system and type of livestock.

2. Livestock feed and feed technologies implemented by farmers vary from agroecological zone to agro-ecological zone.

3. Selection of livestock feed and feed practices to grow and use depends on availability of germplasm (seed, seedling, cuttings etc.), inputs, previous knowledge and ease of establishment and management.

\section{Research Questions}

1. Are farmers adopting feed and feed practices promoted by the EADD Project? Why or why not? 
2. What livestock feed and practices promoted by VFTs do farmers grow and use on their farms?

3. What are the factors that determine the selection of livestock feed and feed practices to be grown and used on farms? 


\subsection{Methodology}

\subsection{Description of study sites}

EADD works in 21 sites in Kenya which are managed by POs spread out in several districts. The study was undertaken in 2012 in 9 PO sites. These were Kabiyet, Sirikwa, Metkei, Taragoon, Olenguruone, Sot, Siongiroi, Cherobu and Olkalou. These sites were selected to represent the different agroecological zones (AEZ) and different farming systems. Kabiyet, Siongiroi and Sirikwa fall in the Upper Midlands; Olkalou, Olenguruone and Metkei are in the Upper Highland (UH); Sot, Cherobu and Taragoon are in the lower highland (Table 1).

Table 1: Description of study sites

\begin{tabular}{llrllll}
\hline Region & PO & $\begin{array}{l}\text { Date } \\
\text { Engagement }\end{array}$ & AEZ & $\begin{array}{l}\text { Feeding } \\
\text { System }\end{array}$ & Elevation (m) & $\begin{array}{l}\text { Rainfall } \\
(\mathbf{m m})\end{array}$ \\
\hline North Rift & Kabiyet & February-09 & UM & GSF,G & $1600-2000$ & $1200-1600$ \\
South Rift & Siongiroi & November-08 & UM & GSF, G & $1800-1900$ & $1400-1650$ \\
North Rift & Sirikwa & June-10 & UM & GSF,G & $1500-2000$ & $1500-2000$ \\
Central Kenya & Olkalou & January-08 & UH & ZG, SFG & $2400-3000$ & $1150-1600$ \\
South Rift & Olenguruone & September-09 & UH & GSF,G & $2400-2970$ & $1200-1800$ \\
North Rift & Metkei & February-09 & UH & GSF,G & $2350-2800$ & $1150-1700$ \\
South Rift & Sot & February-09 & LH & ZG, GSF, G & $1900-2350$ & $1200-1500$ \\
South Rift & Cherobu & September-09 & LH & ZG, GSF, G & $1850-2350$ & $1200-1500$ \\
North Rift & Taragoon & June-08 & LH & GSF,G & $2000-2350$ & $900-1500$ \\
\hline
\end{tabular}

GSF- grazing and some stall feeding; G - pure grazing; ZG- zero grazing UM-Upper midland; UH-Upper highlands; LH-Lower highlands

In the study sites, smallholder dairy production is combined on farm with the cultivation of coffee, tea and food crops - mainly maize, beans, potatoes and market vegetables. The cattle feeding systems vary considerably and include zero grazing where cattle are confined and stall-fed, pure grazing where cattle graze freely on private land in paddocks, and grazing with some stall-feeding where cattle are grazed on private land but supplemented with extra feeds for stall feeding at night (Lukuyu et al 2011). Kabiyet, Siongiroi, Sirikwa, Metkei, Olenguruone and Taragoon are characterized by pure grazing and a few farms with grazing and some stall-feeding. Olkalou is characterized by stallfeeding and some grazing while Sot and Cherobu are characterized by pure grazing, zero grazing and grazing with some stall feeding (Table 1). 
Improved livestock feed technologies/practices disseminated to farmers in the EADD project sites

\section{Forage species/varieties}

- Improved Napier grass varieties (KAK,1 KAK2, EX Mariakani, Clone 13,

- Bana grass, French Cameroon).

- Hyparrhenia rufa

- Columbus grass

- Guatemala grass

- Giant setaria

- Oats

- Forage sorghum (Kinyaruka, JB 26, BM 30, Lanet I, Kaw Kandy, E6518 and E1291)

- Fodder shrubs such as calliandra (Calliandra calothyrsus), tree lucerne (Chamaecytisus palmensis), Leucaena trichandra, mulberry (Morus alba)

- Rhodes grass commonly known as Boma Rhodes (Chloris gayana)

- Desmodium spp intercrop

- Lucerne

- Lupin

- Dual-purpose sweet potato vines: Mugande, SPK 013 and Mafuta, Naspot1, Kemb23 Kemb 36, Gweri, Wagabolige and 103001

- Mangold (Beta vulgaris)

- Burgundy bean (Macroptilium bracteatum)

- Clitoria ternatea

- Vetch (Vicia villosa-dasycarpa)

- Pigeon pea (Cajanus cajan)

- Canavalia brasiliensis

- Dolichos (Lablab purpureus) 


\section{Types of Demonstrations/Practices}

- Napier grass and Desmodium spp.(green leaf and silver leaf) intercrop

- Feed ration formulation (total mixed rations) using locally available materials such as Napier grass, natural pastures, cotton cake, wheat bran, maize bran, maize germ, fodder shrubs and fodder legumes as ingredients

- Pasture improvement through bush clearing, paddocking, spot and strip sowing with legumes

- Feed conservation through tube silage and above-ground silage

- Feed conservation through box baling hay

- Improved storage, processing and utilization of crop residue e.g. dry maize stover using pulverizers and chaff cutters

\subsection{Sampling}

The study was carried out in the EADD project sites. The POs where the study was carried out were purposefully selected. These are the sites where ICRAF dissemination facilitators provided the list of farmers belonging to Dairy Management Groups (DMGs). The POs belong to different AEZs and feeding systems. In the selected POs, a list of 3234 farmers who have been trained and belong to DMGs was obtained. The $181(5 \%)$ farmers to be interviewed were randomly sampled using STATA statistical software. Locations of interviewed farmers are shown in Figure 1.

Table 2: Number of farmers interviewed

\begin{tabular}{llc}
\hline Region & PO & $\begin{array}{c}\text { No of } \\
\text { farmers }\end{array}$ \\
\hline North Rift & Kabiyet & 19 \\
South Rift & Siongiroi & 23 \\
North Rift & Sirikwa & 18 \\
Central Kenya & Olkalou & 21 \\
South Rift & Olenguruone & 12 \\
North Rift & Metkei & 29 \\
South Rift & Sot & 26 \\
South Rift & Cherobu & 12 \\
North Rift & Taragoon & 21 \\
\hline Total & & $\mathbf{1 8 1}$ \\
\hline
\end{tabular}




\subsection{Data collection}

Collection of data was through a formal survey that was conducted by interviewing individual farmers using structured questionnaires. The questionnaires were designed to collect information on farmer preferences, ranking of feeds and socioeconomic data. Questionnaires were used to capture the quantitative data that would enable us understand the factors that influence farmer uptake and preference of feeds and feed practices.

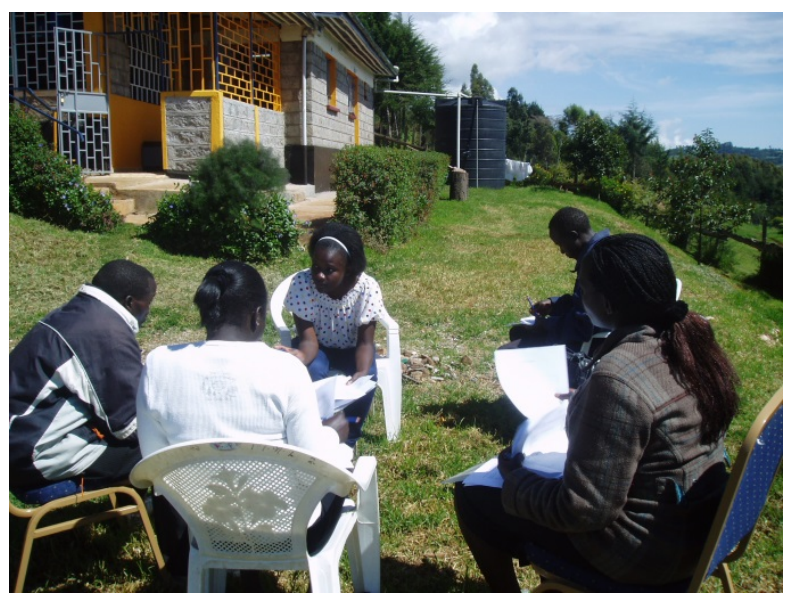

Training enumerators in Metkei PO 

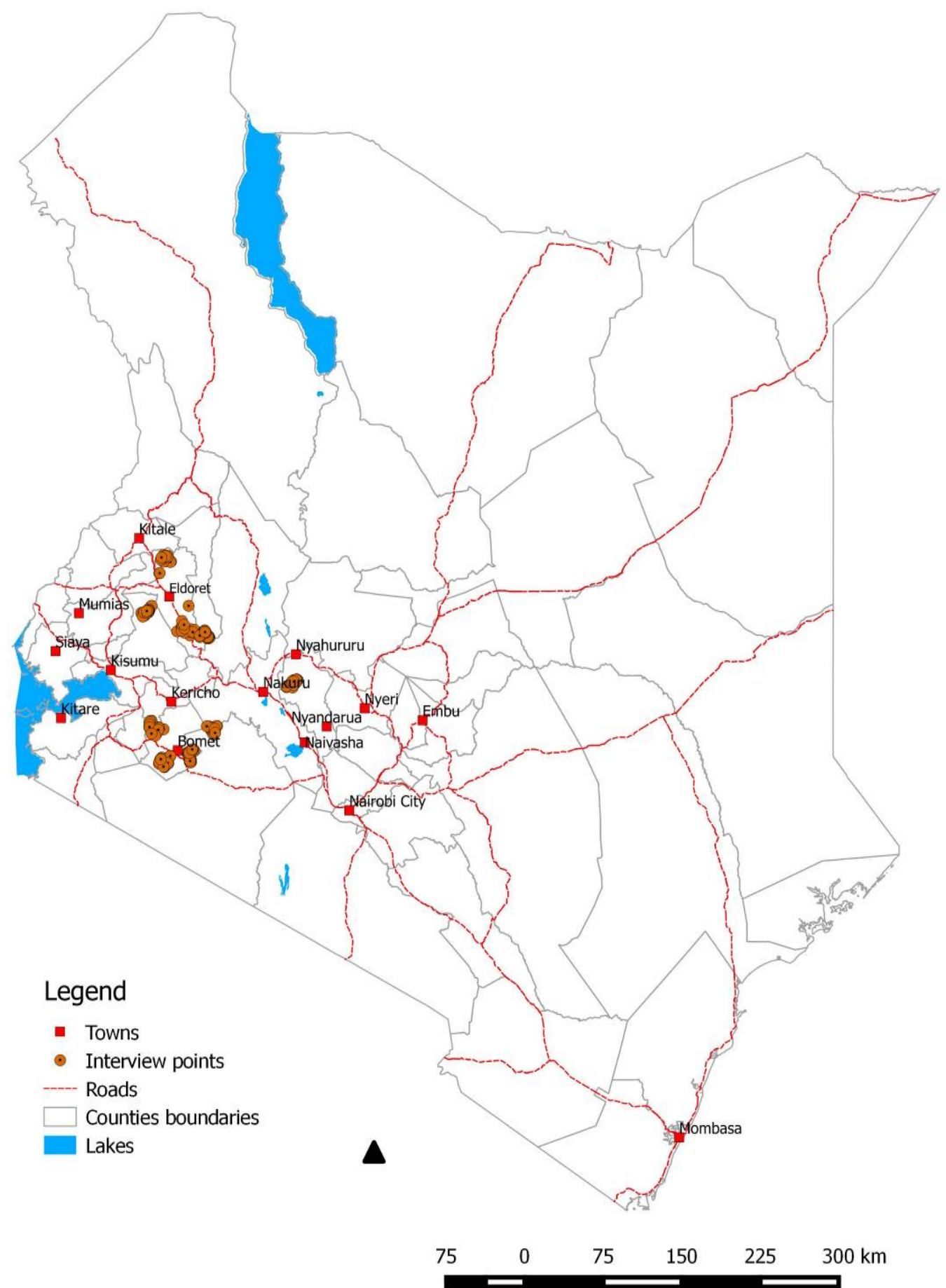

Figure 1: Map of Kenya showing interview locations 


\subsection{Results}

\subsection{Demographic and socioeconomic characteristics of respondents}

Farmers interviewed comprised 60 percent men and 40 percent women (Table 2). The farmers were middle-aged (about 44 years old) with an average of about 46 years and 41 years respectively for men and women. There was a statistically significant difference between the ages of men and women at $p<0.10$. Very few farmers (less than $3 \%$ ) did not have any education (Table 3). Slightly below half of the men had attained secondary education compared to half of the female respondents. More men than women had tertiary (college) level education. In relation to group membership, 86 percent of the farmers interviewed belonged to groups. There was however a higher proportion of males in groups compared to their female counterparts ( $89 \%$ to $83 \%)$. This is in contrast to most studies in Kenya that have shown that more women than men belong to groups.

Table 3: Age, literacy levels and group membership of respondents by gender

\begin{tabular}{|l|c|c|c|}
\hline & $\begin{array}{c}\text { All respondents } \\
(\mathrm{n}=181)\end{array}$ & $\begin{array}{c}\text { Male } \\
(\mathrm{n}=109)\end{array}$ & $\begin{array}{c}\text { Female } \\
(\mathrm{n}=72)\end{array}$ \\
\hline Average age* (years) & $43.9(12.6)$ & $45.7(13.2)$ & $41.2(11.2)$ \\
\hline Education & & & \\
\hline None (\%) & 2.8 & 1.8 & 4.1 \\
\hline Primary (\%) & 30.6 & 27.8 & 34.7 \\
\hline Secondary (\%) & 44.4 & 49 & 50 \\
\hline College (\%) & 17.2 & 21.2 & 11.1 \\
\hline Group membership & 86.3 & 88.6 & 82.5 \\
\hline
\end{tabular}

Significance level $* \mathrm{p}<0.10$. Figures in parenthesis are standard deviations

Overall land owned averaged about 13 acres with female-headed households (FHH) owning only 40 percent as much land as their male counterparts (Table 4). Male-headed households (MHH) also had about one and a half as much land under pasture compared to FHH. FHH rented about 30 percent more land than MHH, perhaps due to the fact that they owned less land. The difference is statistically significant at $\mathrm{P}<0.01$.This confirms studies that have been done in the past that have shown the disadvantaged position of FHH in relation to ownership and access to resources such as land (Croppenstedt et al 2013, Mclntyre et al 2010). About 15 percent of MHH leased land compared to 11 percent of FHH. Distance to the nearest main road was about $1 \mathrm{~km}$ for both types of households with the nearest source of water being about $1 \mathrm{~km}$. 


\section{Main enterprises on the farm}

There were four main enterprises practiced by farmers interviewed in the project sites. These are in order of importance: dairy farming, food crops, poultry and cash crops (Table 5). Both MHH and FHH mentioned dairy and crop farming as their first and second most important enterprises. This was followed by poultry for MHH and cash crops for FHH.

Table 4: Socio-economic characteristics of households in the project sites.

\begin{tabular}{|l|c|c|c|}
\hline Variable & Male HH (n=164) & $\begin{array}{c}\text { Female HH } \\
(\mathrm{n}=17)\end{array}$ & All households \\
\hline Land owned (acres) & $13.8(55.6)$ & $5.5(5.0)$ & $13.1(53.2)$ \\
\hline Land rented (acres) ${ }^{* *}$ & $3.0(3.4)$ & $11.5(10.6)$ & $3.7(4.5)$ \\
\hline Land cultivated (acres) & $8.3(48)$ & $2.4(2.3)$ & $7.8(45.8)$ \\
\hline Land fallow (acres) & $4.3(9.6)$ & $3.6(4.7)$ & $4.3(9.3)$ \\
\hline Land under pasture (acres) & $2.7(4.1)$ & $1.7(1.4)$ & $2.6(4.0)$ \\
\hline How much for land rent in KES & $8925.7(14285.4)$ & 20500 & 10112.8 \\
& & $(26451.2)$ & $(15826.7)$ \\
\hline Distance to nearest main road in $\mathrm{M}^{*}$ & $130.3(201.9)$ & $105.2(167.2)$ & $127.9(198.6)$ \\
\hline Distance to nearest source of water in M & $135.1(186.4)$ & $137.9(169.1)$ & $135.4(184.2)$ \\
\hline
\end{tabular}

Figures in parenthesis are standard deviations. Significance level $* \mathrm{p}<0.10,{ }^{* * *} \mathrm{p}<0.01$.

Table 5: Main enterprises on farm by type of households

\begin{tabular}{|l|r|r|r|}
\hline Enterprise & $\begin{array}{r}\text { Total sample } \\
(\mathrm{n}=181)\end{array}$ & $\begin{array}{r}\text { Male HH } \\
(\mathrm{n}=164)\end{array}$ & Female HH (n=17) \\
\hline & \multicolumn{3}{|c|}{ Percentage of households } \\
\hline Dairy & 95.5 & 95.7 & 94.1 \\
\hline Food crops & 86.1 & 87.1 & 76.4 \\
\hline Poultry & 70.1 & 71.3 & 47 \\
\hline Cash crops & 59.1 & 59.8 & 52.9 \\
\hline
\end{tabular}




\section{Main crops grown}

Crops grown by over 50 percent of the households were maize and beans (Table 6). Cash crops such as tea, wheat, sugarcane and pyrethrum were grown by less than 20 percent of the households with the majority growing tea (13.8\%). None of the FHH grew cash crops such as wheat and sugarcane, perhaps due to the fact that they had less land as was shown in Table 3.

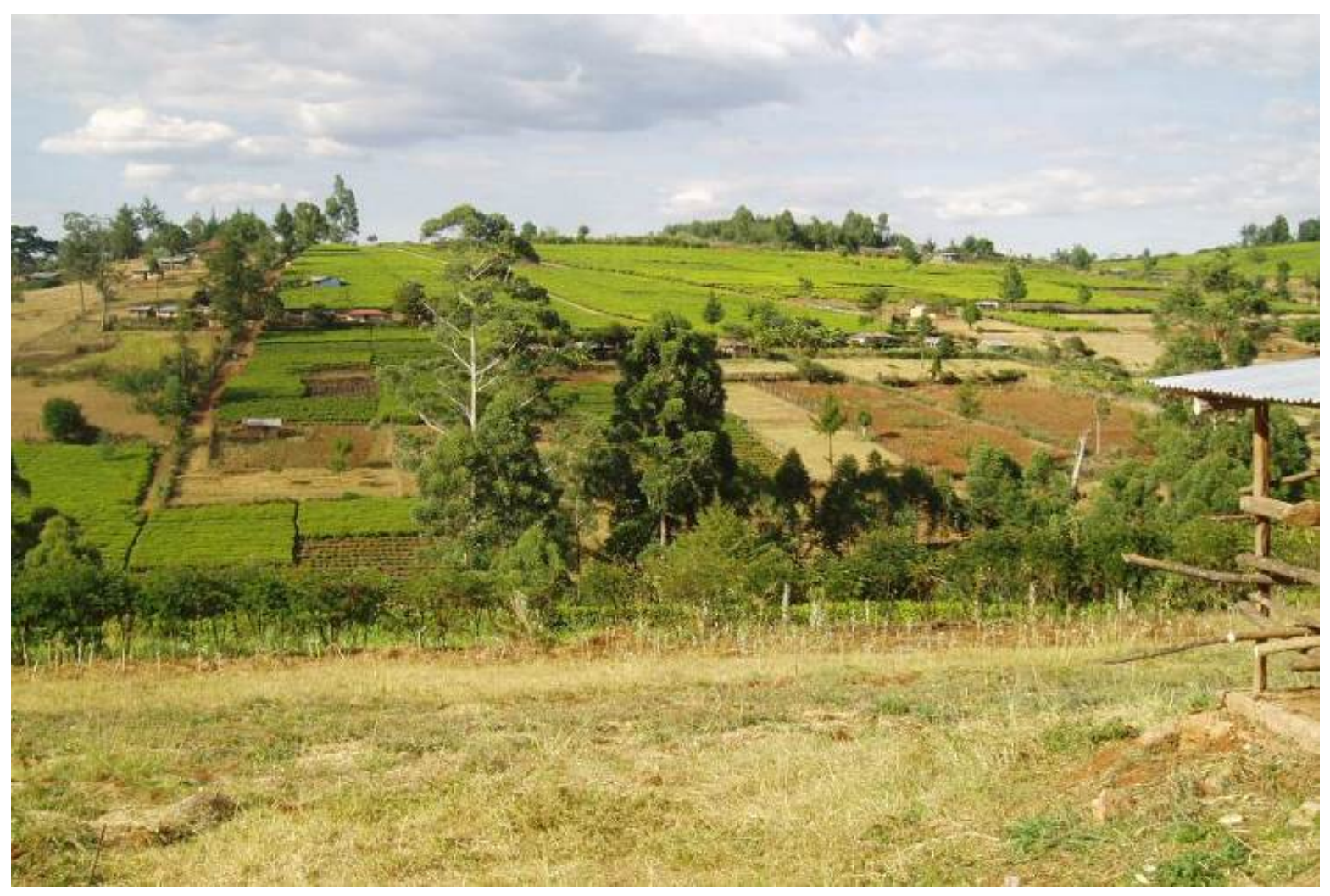

Tea in the background 
Table 6: Main crops grown on the farm

\begin{tabular}{|l|l|l|l|l|}
\hline & All HH (N=181) & \begin{tabular}{l} 
Male $(\mathrm{N}=164)$ \\
\multicolumn{2}{|c|}{ Percentage of households }
\end{tabular} \\
\hline & \multicolumn{3}{|c|}{ Female HH (N=17) } \\
\hline Maize & 84.0 & 84.1 & 82.4 \\
\hline Beans & 51.9 & 53.0 & 41.2 \\
\hline Sweet potatoes & 34.8 & 34.8 & 35.3 \\
\hline Vegetables & 29.8 & 29.9 & 29.4 \\
\hline Tea & 13.8 & 14.0 & 11.8 \\
\hline Wheat & 8.8 & 9.8 & 0.0 \\
\hline Irish potatoes & 8.8 & 3.0 & 5.9 \\
\hline Peas & 6.1 & 6.1 & 5.9 \\
\hline Bananas & 4.4 & 1.2 & 17.6 \\
\hline Sorghum & 4.4 & 4.9 & 0.0 \\
\hline Millet & 3.3 & 3.7 & 0.0 \\
\hline Sugarcane & 1.1 & 1.2 & 0.0 \\
\hline Soya beans & 1.1 & 1.2 & 0.0 \\
\hline Oats & 1.1 & 1.2 & 0.0 \\
\hline Pyrethrum & 0.6 & 0.6 & 0.0 \\
\hline
\end{tabular}

\section{Livestock ownership}

Livestock owned ranged from pure, cross and local breeds of cattle, goats, sheep and poultry (Table 7). Other types of livestock included rabbits and donkeys. Only 13.8 percent of the households had pure breed dairy cattle with an average of 6 per household. A higher proportion of MHH (14.6\%) had pure breed cows compared to only 5.6 percent of FHH. The majority of farmers (92\%) had cross-breed adult dairy cows; the same average number for both types of households. It is however important to note that all FHH interviewed had cross-breed dairy cattle compared to 91 percent of their male counterparts. 
Table 7: Number and type of livestock owned

\begin{tabular}{|c|c|c|c|c|c|c|}
\hline & $\begin{array}{l}\text { Total } \\
(\mathrm{n}=181)\end{array}$ & sample & $\mathrm{MHH}(\mathrm{n}=$ & 64) & $\mathrm{FHH}(\mathrm{n}=1$ & \\
\hline Variable & $\%$ & Mean & $\%$ & Mean & $\%$ & Mean \\
\hline Cross-breed adult dairy cattle & 92.3 & $3(3)$ & 91.5 & $3(3)$ & 100.0 & $3(2)$ \\
\hline Cross-breed calves & 76.8 & $3(3)$ & 76.8 & $3(4)$ & 76.5 & $2(1)$ \\
\hline Local poultry & 74.0 & $13(12)$ & 75.0 & $13(12)$ & 64.7 & $12(7.8)$ \\
\hline Cross-breed sheep & 26.5 & $4(3)$ & 27.4 & $4(3)$ & 17.6 & $4(1)$ \\
\hline Pure breed adult dairy cattle & 13.8 & $6(12)$ & 14.6 & $6(12)$ & 5.9 & 1 \\
\hline Pure breed calves & 13.8 & $3(4)$ & 14.0 & $3(4)$ & 11.8 & $2(1)$ \\
\hline Cross breed beef cattle & 12.7 & $3(4)$ & 13.4 & $3(4)$ & 5.9 & 2 \\
\hline Local sheep & 11.0 & $10(20)$ & 10.4 & $11(20)$ & 17.6 & $2(2)$ \\
\hline Donkeys & 11.0 & $1(1)$ & 11.6 & $1(1)$ & 5.9 & 1 \\
\hline Local goats & 9.4 & $11(18)$ & 8.5 & $13(19)$ & 17.6 & $2(2)$ \\
\hline Improved local poultry & 9.4 & $24(25)$ & 8.5 & $28(26)$ & 17.6 & $6(5)$ \\
\hline Pure breed sheep & 8.3 & $7(5)$ & 7.9 & $7(5)$ & 11.8 & $9(7)$ \\
\hline Dairy goats cross breed & 7.2 & $5(4)$ & 7.9 & $5(4)$ & 0.0 & 0) \\
\hline Rabbits & 6.6 & $3(2)$ & 7.3 & $3(2)$ & 0.0 & 0 \\
\hline Poultry broilers & 6.6 & $18(27)$ & 6.7 & $19(28)$ & 5.9 & 4 \\
\hline Local beef cattle & 6.1 & $2(1)$ & 5.5 & $2(1)$ & 11.8 & $3(2)$ \\
\hline Poultry layers & 6.1 & $63(92)$ & 6.1 & $69(96)$ & 5.9 & 10 \\
\hline Dairy goats pure breed & 5.5 & $2(2)$ & 5.5 & $2(2)$ & 5.9 & 2 \\
\hline Local adult dairy cattle & 4.4 & $2(1)$ & 3.7 & $2(1)$ & 11.8 & $2(1)$ \\
\hline Local Calves & 3.3 & $2(1)$ & 2.4 & $2(1)$ & 11.8 & $2(1)$ \\
\hline
\end{tabular}

Figures in parenthesis are standard deviations

\section{Asset ownership (chaff cutter and pulverizer)}

A chaff cutter is a mechanical device with or without a motor for cutting fodder into small pieces before mixing together with other forages and feeding to livestock. This is one of the labour-saving technologies promoted by the EADD project to reduce the tasks performed by dairy farmers. About 12 percent of the households had chaff cutters. A higher proportion of FHH had chaff cutters compared to MHH (Table 8). However, none of the FHH had a pulverizer whereas 7 percent of $\mathrm{MHH}$ owned it. A pulverizer is a type of mechanical devise that grinds different types of materials. In the EADD project, it is promoted to farmers for grinding maize stovers and other feeds. 


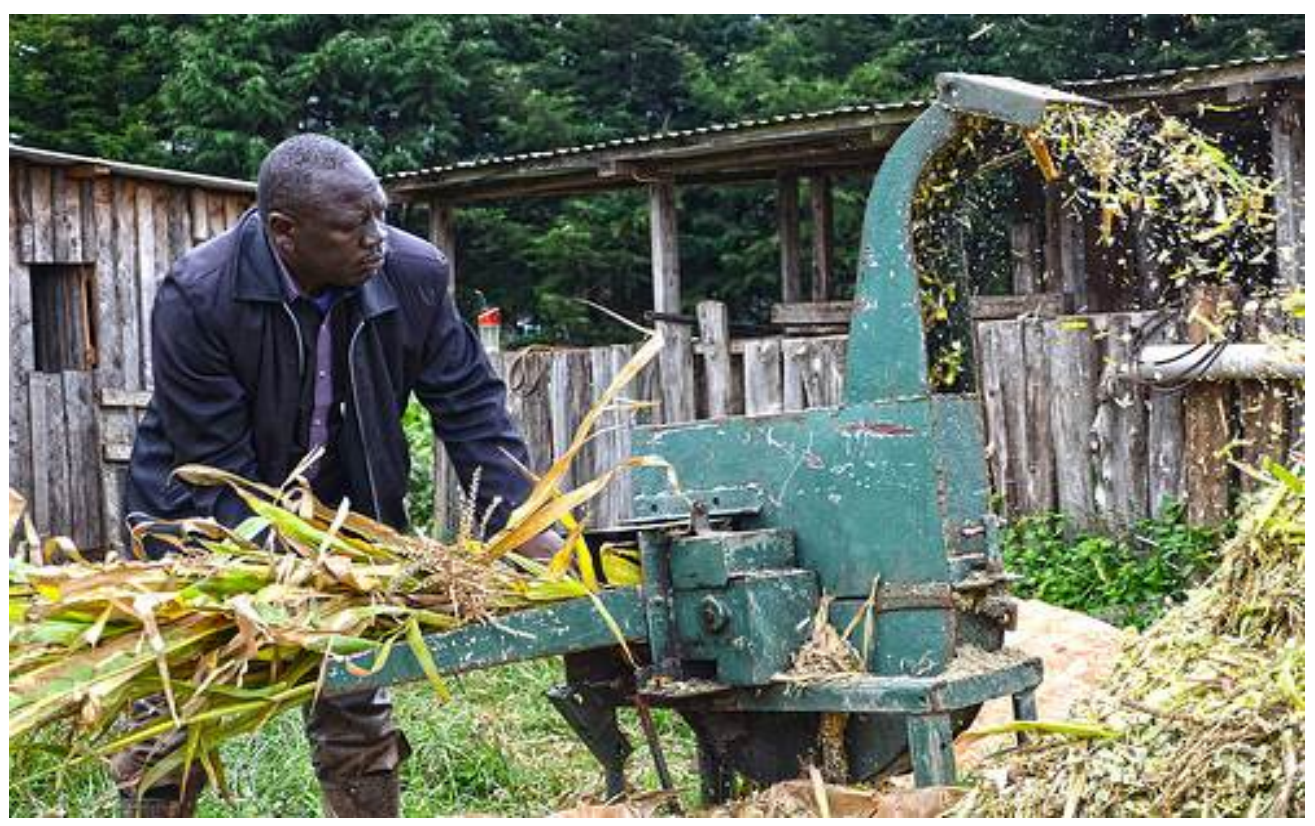

A farmer trainer, Francis Warui, using a chaff cutter in Olkalou

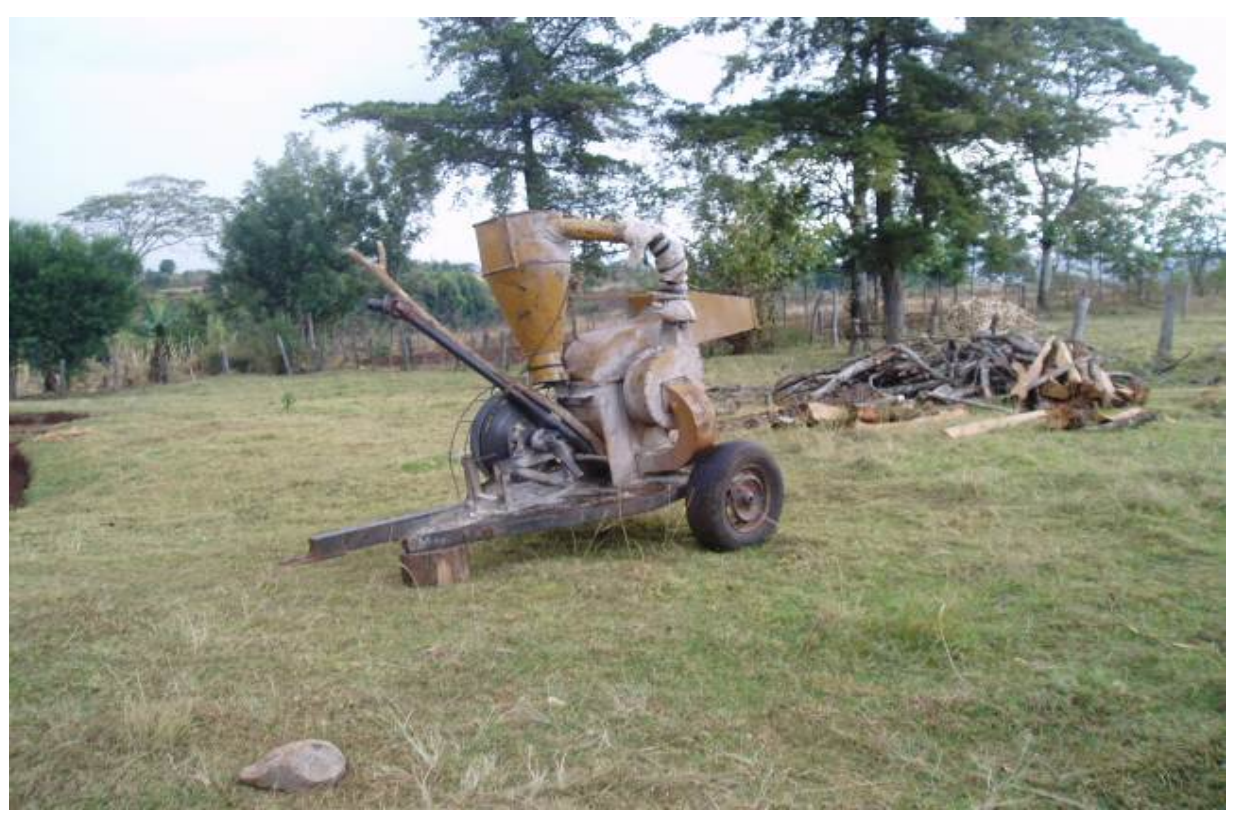

A modified pulverizer in Rift valley 
Table 8: Ownership of chaff cutter and pulverizer by type of household

\begin{tabular}{lrccc}
\hline & $\begin{array}{c}\text { MHH } \\
(\mathrm{n}=164)\end{array}$ & $\begin{array}{c}\text { FHH } \\
(\mathrm{n}=17)\end{array}$ & $\begin{array}{l}\text { Total } \\
(\mathrm{n}=181)\end{array}$ & HH \\
& & \multicolumn{2}{c}{ Percentage of households } \\
\hline $\begin{array}{l}\text { Chaff } \\
\text { cutter } \\
\text { Pulverizer }\end{array}$ & 11.5 & 17.6 & 12.1 \\
\hline
\end{tabular}

When data was categorized by site, a high proportion of households in Olkalou owned a chaff cutter compared to other sites. This was followed by Siongiroi and Kabiyet (Table 9). As for the pulverizer, a higher proportion of households in Kabiyet owned it followed by Taragoon and Sirikwa. Note that none of the households in Taragoon, Metkei and Olenguruone had chaff cutters while none of the households in Metkei, Sot and Siongiroi had pulverizers. This is a result of the costs which are too prohibitive. A manual chaff cutter costs about KES 20000 while a motorized one is about KES 35000 . The cost for the pulverizer ranges between KES 35 000-100 000 depending on the quality and output.

Table 9: Ownership of chaff cutter and pulverizer by site

\begin{tabular}{|l|c|c|c|c|}
\hline & \multicolumn{2}{|c|}{ Chaff cutter } & \multicolumn{2}{c|}{ Pulverizer } \\
\hline & $\mathrm{N}$ & $\%$ & $\mathrm{~N}$ & $\%$ \\
\hline All sites & 181 & 12.1 & 181 & 6.63 \\
\hline Kabiyet & 19 & 21.05 & 19 & 21.05 \\
\hline Sirikwa & 18 & 5.56 & 18 & 11.11 \\
\hline Taragoon & 21 & 0 & 21 & 14.29 \\
\hline Metkei & 29 & 0 & 29 & 0 \\
\hline Cherobu & 12 & 8.33 & 12 & 8.33 \\
\hline Olkalou & 21 & 33.33 & 21 & 4.76 \\
\hline Sot & 26 & 3.85 & 26 & 0 \\
\hline Siongiroi & 23 & 30.43 & 23 & 0 \\
\hline Olenguruone & 12 & 0 & 12 & 8.33 \\
\hline
\end{tabular}




\subsection{Experience in dairy farming and awareness of livestock feeds and practices}

\section{Dairy farming experience}

A majority of farmers interviewed (95\%) had dairy farming experience ranging from 1 year to 57 years. The average years of dairy experience for male farmers was 13 years compared to 11 years for females. About 31 percent of farmers interviewed had between 1 and 5 years of experience in dairy farming while 7 percent had between 41 and 57 years of experience (Table 10).

Table 10: Years of experience in dairy farming

\begin{tabular}{|c|c|}
\hline Years of experience & $\begin{array}{c}\text { Percentage of farmers } \\
(\mathbf{N}=\mathbf{1 8 1})\end{array}$ \\
\hline $1-5$ & 30.9 \\
\hline $6-10$ & 27.6 \\
\hline $11-15$ & 16.0 \\
\hline $16-20$ & 6.6 \\
\hline $21-25$ & 4.4 \\
\hline $25-30$ & 3.9 \\
\hline $31-40$ & 1.7 \\
\hline $41-57$ & 3.9 \\
\hline
\end{tabular}

\subsection{Farmers' awareness of feeds and feed technologies promoted by EADD}

All farmers interviewed had knowledge on the improved feed and feed practices introduced by the EADD project and other institutions. Among grasses, almost all respondents were aware of Napier grass and about three-quarters were aware of Boma Rhodes (Table 11). Between 20 and 30 percent of the farmers were aware of Nandi setaria and Columbus grass. Grasses that farmers were less aware of (less than 5\%) were Sudan grass, molasses grass, giant setaria, serato, Elimba Rhodes among many other grasses that have been classified in Table 10 as other grasses. Among herbaceous legumes, lucerne was the most known by 74 percent of the farmers compared to desmodium (42\%). Less known herbaceous legumes (less than 10\%) were vetch, lupin and lablab. Among the fodder shrubs, calliandra was the most known followed by sesbania. 
Table 11: Percentage of farmers aware of feeds/feed practices promoted by EADD project

\begin{tabular}{|c|c|c|}
\hline & Feeds and Practices & $\begin{array}{c}\% \text { of } \\
\text { farmers } \\
(\mathrm{n}=181)\end{array}$ \\
\hline \multirow[t]{5}{*}{ Grasses } & Napier & 99.4 \\
\hline & Boma Rhodes & 75.1 \\
\hline & Nandi setaria & 26 \\
\hline & Columbus grass & 28.2 \\
\hline & Other grasses & 13.9 \\
\hline \multirow[t]{5}{*}{ Herbacious legumes } & Lucerne & 73.5 \\
\hline & Desmodium & 42 \\
\hline & Lupin & 9.9 \\
\hline & Purple vetch & 1.1 \\
\hline & Lablab & 2.2 \\
\hline \multirow[t]{5}{*}{ Fodder shrubs } & Calliandra & 36.5 \\
\hline & Sesbania & 12.7 \\
\hline & Leucaena trichandria & 5 \\
\hline & Mulbery & 9.4 \\
\hline & Tree Lucerne & 3.9 \\
\hline \multirow[t]{4}{*}{ Other fodder crops } & Oats & 63 \\
\hline & Sweet potato vines & 44.2 \\
\hline & Forage sorghum & 37 \\
\hline & Yellow maize & 0.6 \\
\hline \multirow[t]{10}{*}{ Crop residues } & Maize stover dry & 42 \\
\hline & Maize stover green & 20.4 \\
\hline & Bean husks & 30.9 \\
\hline & Sunflower cake & 21.5 \\
\hline & Wheat straws & 8.8 \\
\hline & Millet straws & 3.3 \\
\hline & Maize ground & 15.5 \\
\hline & Barley straws & 0.6 \\
\hline & Sugarcane residues & 7.7 \\
\hline & Other crop residues & 7.8 \\
\hline \multirow[t]{5}{*}{ Feed Practices } & Silage & 40.9 \\
\hline & Hay & 24.9 \\
\hline & Dairy meal/commercial concentrates & 19.9 \\
\hline & Feed/ration formulation & 7.2 \\
\hline & Home- made concentrates & 1.7 \\
\hline
\end{tabular}

NB: Kikuyu grass and other common livestock feeds such as banana pseudo stems, and vegetable residues used by farmers have not been included since they are not among those promoted by EADD project. 
Less known were tree lucerne, Leuceana trichandria and mulberry. Among other fodder crops, 63 percent of the farmers were aware of oats and 37 percent were aware of forage sorghum. Farmers were aware of the use of several crop residues as livestock feed, with dry maize stover mentioned by 42 percent of the respondents, bean husks by 31 percent and green maize stover by 20 percent. Among feed practices, 41 percent of the farmers knew about silage. Less than 30 percent of the farmers knew other feed practices (Table 11 ), and less than 2 percent knew about home-made concentrates.

\subsection{Sources of information on feeds and feed practices}

Dairy farmers have multiple sources of information. VFTs, Ministry of Livestock (MOL) and other farmers were the three main sources of information for both men and women dairy farmers (Table 12). This is attributed to the fact that farmers interviewed belonged to DMGs which mostly receive training from VFTs.

Table 12: Sources of information between genders

\begin{tabular}{|l|l|l|}
\hline Source of information & $\begin{array}{l}\text { Male } \\
(\mathrm{N}=109)\end{array}$ & $\begin{array}{l}\text { Female } \\
(\mathrm{N}=72)\end{array}$ \\
\hline Volunteer farmer trainer (VFT) & 57.9 & 45.5 \\
\hline Ministry of Livestock & 35.7 & 33.3 \\
\hline Other farmers & 34.3 & 26.7 \\
\hline EADD & 21.4 & 24.4 \\
\hline Ministry of Agriculture (MOA) & 24.3 & 21.1 \\
\hline Home/family members & 23.6 & 23.3 \\
\hline Farmer field days & 25.7 & 18.9 \\
\hline Community Extension Service Providers (CESPs) & 12.1 & 17.8 \\
\hline Exchange visits & 15.7 & 6.7 \\
\hline Neighbours & 10.0 & 10.0 \\
\hline Agriculture Society of Kenya shows & 11.4 & 7.8 \\
\hline NALEP & 2.1 & 8.9 \\
\hline Agrovets/stockists & 10.6 & 2.2 \\
\hline Radio & 5.0 & 3.3 \\
\hline Producer organization & 1.4 & 2.2 \\
\hline Own trials & 2.1 & 1.1 \\
\hline KARI & 2.9 & 1.1 \\
\hline Catholic church & 0.0 & 1.1 \\
\hline Written material (books, brochures) & 1.4 & 1.1 \\
\hline
\end{tabular}




\section{Sources of information for grasses}

For grasses such as Napier, Boma Rhodes and Nandi setaria, more than 20 percent of farmers received information from VFTs (Table 13). This is an indication that VFTs are an important source of information for these technologies. Other important sources of information for Napier grass were other farmers and Ministries of Agriculture (MOA) and Livestock (10\% and 14.6\% respectively). For Boma Rhodes and Nandi setaria, other important sources other than VFTs are the EADD project and CESPs.

Table 13: Sources of information for grasses

\begin{tabular}{|l|r|l|r|}
\hline Sources & Napier $(\mathrm{n}=178)$ & $\begin{array}{l}\text { Boma } \\
(\mathrm{n}=133)\end{array}$ & Rhodes \\
& \multicolumn{3}{|c|}{ Percentage of farmers } \\
\hline & 25.3 & 24.1 & 26.1 \\
\hline VFT & 14.6 & 9.0 & 0 \\
\hline MOL & 11.8 & 7.5 & 13.0 \\
\hline Other farmer & 10.1 & 3.0 & 0 \\
\hline MOA & 9.0 & 1.5 & 4.4 \\
\hline Home & 7.9 & 18.8 & 13.0 \\
\hline EADD & 6.2 & 17.3 & 13.0 \\
\hline CESPs & 4.5 & 0 & 4.4 \\
\hline Neighbour & 3.4 & 6.0 & 10.9 \\
\hline Farmer field days & 2.3 & 0 & 0 \\
\hline NALEP & 1.7 & 0.8 & 0 \\
\hline Farmer group & 1.1 & 4.5 & 2.2 \\
\hline Exchange visits & 1.1 & 1.5 & 0 \\
\hline KARI & 0.6 & 0 & 0 \\
\hline Catholic church & 0.6 & 0 & 0 \\
\hline Demonstrations & 0 & 2.3 & 2.2 \\
\hline ASK shows & 0 & 0 & 2.2 \\
\hline Radio & 0 & 0 & 0 \\
\hline Local market & 0 & 0.8 & 0 \\
\hline Agrovet & 0 & 3.0 & \\
\hline PO & & & \\
\hline
\end{tabular}




\section{Sources of information on herbaceous fodder legumes}

The most common sources of information for herbaceous fodder legumes are VFTs, CESPs, EADD project and the MOL (Table 14). Slightly less than 30 percent of the farmers who were aware of lucerne obtained information from VFTs followed by the EADD project and CESPs. Twenty-six (26) percent of the farmers obtained information on desmodium from the EADD project, followed by CESPs and MOL.

Table 14: Percentage of farmers obtaining information on herbaceous fodder legumes from different sources

\begin{tabular}{|l|c|c|}
\hline Information sources & Lucerne $(\mathrm{n}=129)$ & Desmodium $(\mathrm{n}=73)$ \\
\hline & \multicolumn{2}{|c|}{$\%$ of farmers } \\
\hline VFTs & 28.7 & 13.7 \\
\hline CESPs & 14.7 & 24.7 \\
\hline EADD & 14.7 & 26.0 \\
\hline MOL & 8.5 & 15.1 \\
\hline Farmer field days & 7.8 & 5.5 \\
\hline MOA & 6.2 & 1.4 \\
\hline Exchange visits & 4.7 & 7.0 \\
\hline Other farmer & 4.7 & 1.4 \\
\hline Home & 2.3 & 1.4 \\
\hline PO & 2.3 & 1.4 \\
\hline ASK show & 1.6 & 0 \\
\hline Radio & 1.6 & 0 \\
\hline Agrovet & 0.9 & 0 \\
\hline KARI & 0.8 & 1.4 \\
\hline NALEP & 0.8 & 1.4 \\
\hline Farmer groups & 0 & \\
\hline
\end{tabular}

\section{Sources of information on fodder shrubs}

Farmers accessed information on fodder shrubs mainly from EADD project, CESPs, VFTs and MOL (Table 15). More specifically, 32 percent of the farmers accessed information on calliandra from the EADD project followed by CESPs $(24.6 \%)$ and VFTs (15\%). About 22 percent of farmers accessed information on Leuceana trichandria from MOL while 35 percent accessed information on mulberry from the EADD project, 
followed by VFTs and CESPs. About 43 percent of the farmers accessed information on tree lucerne from VFTs and 28.6 percent from other farmers (Table 14).

\section{Sources of information on other fodder crops, crop residues and feed practices}

Farmers accessed information on other fodder crops such as oats, forage sorghum, sweet potato vines and sunflower cake mainly from VFTs, CESPs and the EADD project. Information on sugarcane as a fodder crop was mainly accessed from neighbours (Table 16).

Table 15: Sources of information on fodder shrubs

\begin{tabular}{|c|c|c|c|c|}
\hline & Calliandra $(n=65)$ & L. trichandria $(n=9)$ & Mulberry $(n=17)$ & Tree lucerne $(n=7)$ \\
\hline & \multicolumn{4}{|c|}{$\%$ of farmers } \\
\hline EADD & 32.3 & 11.1 & 35.3 & 14.3 \\
\hline CESPs & 24.6 & 0 & 23.5 & 0 \\
\hline VFTs & 15.4 & 11.1 & 29.4 & 42.9 \\
\hline MOL & 10.8 & 22.2 & 0 & 0 \\
\hline Farmer field days & 4.6 & 11.1 & 5.9 & 14.3 \\
\hline Exchange visits & 3.1 & 0 & 5.9 & 0 \\
\hline NALEP & 3.1 & 11.1 & 0 & 0 \\
\hline $\mathrm{PO}$ & 3.1 & 0 & 0 & 0 \\
\hline ASK show & 1.5 & 11.1 & 0 & 0 \\
\hline $\begin{array}{l}\text { Kenya Farmer } \\
\text { Association (KFA) }\end{array}$ & 1.5 & 0 & 0 & 0 \\
\hline Neighbours & 0 & 11.1 & 0 & 0 \\
\hline Other farmer & 0 & 11.1 & 0 & 28.6 \\
\hline
\end{tabular}

Information on crop residues such as maize stover (green and dry) and bean husks was mainly accessed from VFTs, the EADD project and MOL (Table 17). Information on feed practices such as hay and silage-making, sunflower cake, feed formulation and dairy meal was mainly accessed from VFTs, CESPS, MOL and the EADD project (Table 18). 
Table 16: Farmers' access to information on other fodder crops from different sources

\begin{tabular}{|l|c|c|c|c|}
\hline & Oats $\mathrm{n}(113)$ & $\begin{array}{l}\text { Forage } \\
\text { Sorghum (65) }\end{array}$ & $\begin{array}{l}\text { Sweet } \\
\text { potato } \\
\text { vines (n=76 }\end{array}$ & Sugar cane (n=14) \\
\hline VFTs & 31.9 & 13.9 & 18.4 & 21.4 \\
\hline Home & 13.3 & 1.5 & 1.3 & 0 \\
\hline Other farmers & 12.4 & 4.6 & 5.3 & 0 \\
\hline EADD & 9.7 & 20 & 22.4 & 0 \\
\hline CESPs & 8.9 & 27.7 & 14.5 & 21.4 \\
\hline MOL & 7.1 & 10.8 & 15.8 & 14.3 \\
\hline Farmer field days & 6.2 & 1.5 & 1.3 & 0 \\
\hline MOA & 3.5 & 1.5 & 4.0 & 0 \\
\hline Exchange visits & 1.8 & 3.1 & 4.0 & 0 \\
\hline KARI & 1.8 & 1.5 & 0 & 0 \\
\hline ASK show & 0.9 & 1.5 & 4.0 & 0 \\
\hline Radio & 0.9 & 4.6 & 0 & 0 \\
\hline Farmer group & 0.9 & 0 & 0 & 3.14 \\
\hline Demonstrations & 0.9 & 0 & 0 & 0 \\
\hline Neighbours & 0 & 1.5 & 2.6 & 0 \\
\hline Own trials & 0 & 1.54 & 0 & 0 \\
\hline NALEP & 0 & 0 & 2.63 & 0 \\
\hline KFA & 0 & 3.08 & 3.95 & 0 \\
\hline PO & & & & 0 \\
\hline
\end{tabular}


Table 17: Sources of information on crop residues

\begin{tabular}{|c|c|c|c|c|c|}
\hline & $\begin{array}{ll}\text { Maize green } \\
(\mathrm{n}=34)\end{array}$ & $\begin{array}{l}\text { Maize } \\
\text { dry }(\mathrm{n}=69)\end{array}$ & $\begin{array}{ll}\text { Bean } & \text { husks } \\
(=14) & \end{array}$ & $\begin{array}{l}\text { Wheat straw } \\
(\mathrm{n}=45)\end{array}$ & $\begin{array}{l}\text { Sun flower } \\
\text { cake }(n=37)\end{array}$ \\
\hline Other farmer & 26.5 & 18.8 & 7.1 & 13.3 & 10.8 \\
\hline $\mathrm{MOA}$ & 23.5 & 4.4 & 14.3 & 6.7 & 5.4 \\
\hline VFTs & 14.7 & 17.4 & 14.29 & 17.8 & 46 \\
\hline EADD & 8.8 & 1.5 & 0 & 11.1 & 10.8 \\
\hline Home & 5.9 & 20.3 & 0 & 2.2 & 0 \\
\hline Farmer field days & 5.9 & 1.5 & 0 & 4.4 & 0 \\
\hline MOL & 5.9 & 13.0 & 50 & 13.3 & 8.1 \\
\hline ASK show & 5.9 & 0 & 0 & 0 & 2.7 \\
\hline NALEP & 2.9 & 2.9 & 7.1 & 2.2 & 0 \\
\hline CESPs & 0 & 14.5 & 0 & 13.3 & 0 \\
\hline Neighbour & 0 & 2.9 & 7.1 & 0 & 0 \\
\hline Exchange visits & 0 & 1.5 & 0 & 4.4 & 2.7 \\
\hline Own trials & 0 & 1.5 & 0 & 0 & 0 \\
\hline Radio & 0 & 0 & 0 & 2.2 & 0 \\
\hline Farmer group & 0 & 0 & 0 & 6.7 & 16.7 \\
\hline Demonstration & 0 & 0 & 0 & 2.2 & 0 \\
\hline
\end{tabular}


Table 18: Sources of information on feed practices

\begin{tabular}{|l|l|l|l|l|}
\hline & $\begin{array}{l}\text { Hay baling } \\
(\mathrm{n}=45)\end{array}$ & $\begin{array}{l}\text { Silage } \\
\text { making } \\
(\mathrm{n}=72)\end{array}$ & $\begin{array}{l}\text { Feed } \\
\text { formulation } \\
(\mathrm{N}=11)\end{array}$ & $\begin{array}{l}\text { Dairy meal } \\
(\mathrm{N}=15)\end{array}$ \\
\hline VFTs & 17.8 & 29.2 & 45.5 & 46.7 \\
\hline CESP & 13.3 & 9.7 & 0 & 0 \\
\hline EADD & 13.3 & 19.5 & 9.1 & 0 \\
\hline MOA & 13.3 & 9.7 & 0 & 0 \\
\hline Other farmers & 13.3 & 12.5 & 18.2 & 6.7 \\
\hline MOA & 6.67 & 2.8 & 0 & 0 \\
\hline PO & 6.7 & 2.8 & 0 & 0 \\
\hline Farmer field days & 4.4 & 6.9 & 18.2 & 33.3 \\
\hline Exchange visits & 4.4 & 4.2 & 0 & 6.7 \\
\hline Home & 2.2 & 1.4 & 0 & 0 \\
\hline NALEP & 2.2 & 1.4 & 0 & 0 \\
\hline Radio & 2.2 & 0 & 0 & 0 \\
\hline Neighbour & 0 & 0 & 9.1 & 0 \\
\hline ASK show & 0 & 0 & 0 & 0.7 \\
\hline Farmer group & 0 & 0 & 0 & 0 \\
\hline
\end{tabular}

\section{Rating of information sources}

When farmers were asked to rate information sources, VFTs were ranked highest followed by farmer field schools, MOL, EADD project and $5^{\text {th }}$ was the MOA (Table 19). Of the farmers who mentioned VFTs as a source of information, 55 percent rated it as the most important source, followed by 33 percent who rated it as an important source of information while a paltry 3 percent rated it as the least important. During the time of the interviews, Ministry of Agriculture and Ministry of Livestock were separate ministries but they have since been merged to form the Ministry of Agriculture, Livestock and Fisheries Development. Although farmer field schools ranked second overall, farmers who used them rated them highly. 

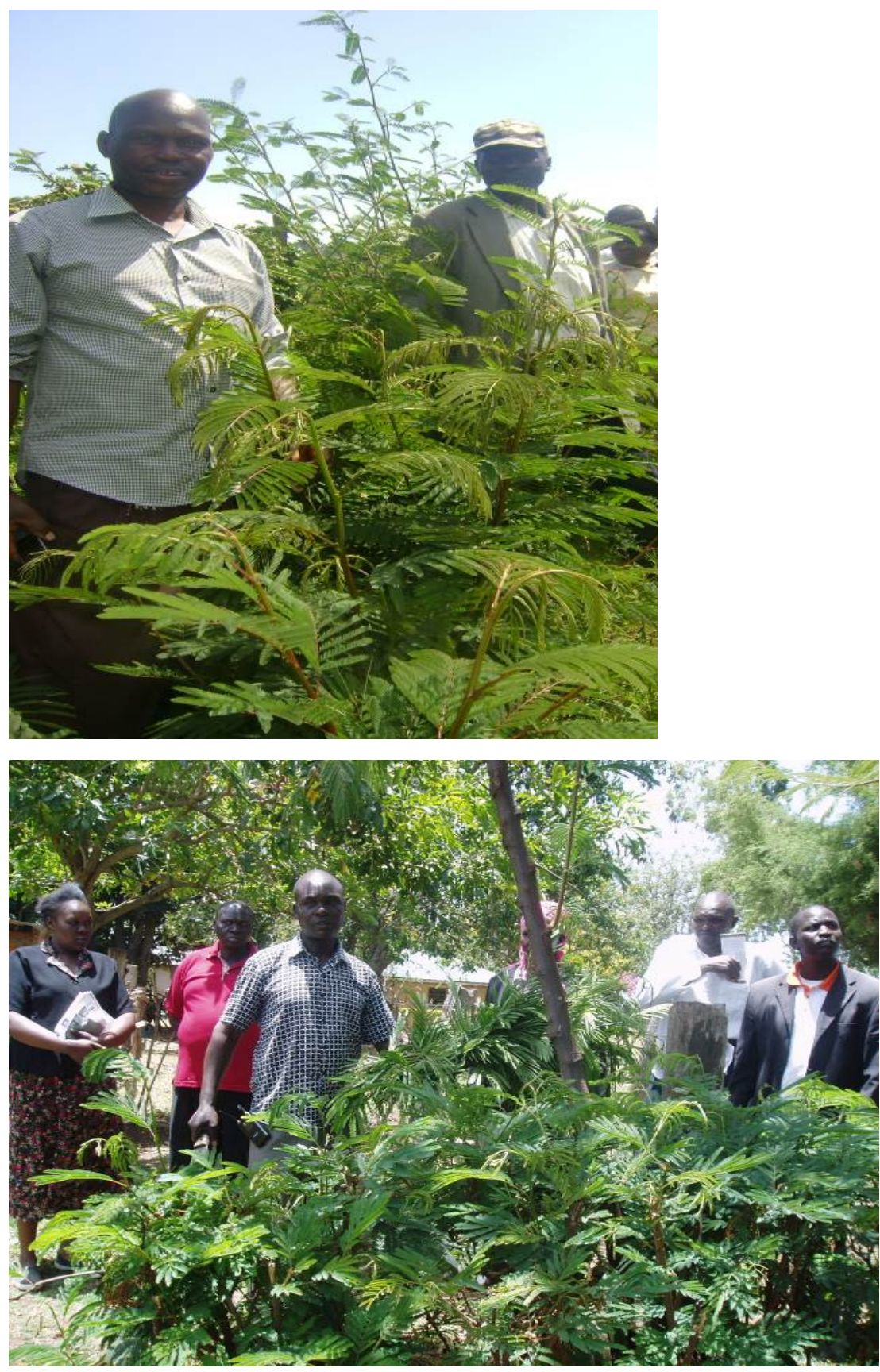

Farmers in Kaptumo learning about calliandra 
Table 19: Rating of information sources

\begin{tabular}{|c|c|c|c|c|c|c|c|c|c|}
\hline & $\begin{array}{l}\text { Most important } \\
\text { (5) }\end{array}$ & $\begin{array}{l}\text { Important } \\
\text { (4) }\end{array}$ & $\begin{array}{l}\text { Neutral } \\
\text { (3) }\end{array}$ & $\begin{array}{l}\text { Less } \\
\text { important } \\
(2)\end{array}$ & $\begin{array}{l}\text { Least } \\
\text { important } \\
\text { (1) }\end{array}$ & & & & $\begin{array}{l}\text { Overall } \\
\text { Rank }\end{array}$ \\
\hline Information source & \multicolumn{5}{|c|}{ Frequency } & $\begin{array}{c}\text { Total } \\
\text { frequency }\end{array}$ & $\begin{array}{l}\text { Total } \\
\text { Score }\end{array}$ & $\begin{array}{r}\text { Average } \\
\text { score }\end{array}$ & \\
\hline VFT & 58 & 35 & 6 & 6 & 3 & 108 & 463 & 4.29 & 1 \\
\hline Farmer field schools & 52 & 23 & 4 & 2 & 2 & 83 & 370 & 4.45 & 2 \\
\hline MOL & 21 & 12 & 13 & 11 & 7 & 64 & 221 & 3.45 & 3 \\
\hline EADD & 27 & 5 & 2 & 3 & 2 & 39 & 169 & 4.33 & 4 \\
\hline MOL & 20 & 8 & 2 & 8 & 4 & 42 & 142 & 3.38 & 5 \\
\hline Other farmers & 13 & 8 & 12 & 3 & 0 & 36 & 139 & 3.86 & 6 \\
\hline CESPs & 17 & 5 & 3 & 2 & 1 & 28 & 119 & 4.25 & 7 \\
\hline Home & 5 & 6 & 13 & 3 & 1 & 28 & 80 & 2.86 & 8 \\
\hline Neighbour & 7 & 2 & 5 & 3 & 1 & 18 & 65 & 3.61 & 9 \\
\hline Exchange visit & 8 & 2 & 0 & 3 & 2 & 15 & 56 & 4.31 & 10 \\
\hline ASK show & 3 & 4 & 3 & 2 & 1 & 13 & 45 & 3.46 & 11 \\
\hline NALEP & 3 & 5 & 1 & 0 & 0 & 9 & 38 & 4.22 & 12 \\
\hline Radio & 4 & 0 & 0 & 0 & 0 & 4 & 20 & 5.00 & 13 \\
\hline Farmer groups & 4 & 0 & 0 & 0 & 0 & 4 & 20 & 5.00 & 13 \\
\hline KARI & 1 & 1 & 0 & 0 & 0 & 2 & 9 & 4.50 & 15 \\
\hline Own trials & 1 & 0 & 0 & 0 & 0 & 1 & 5 & 5.00 & 16 \\
\hline KFA & 1 & 0 & 0 & 0 & 0 & 1 & 5 & 5.00 & 16 \\
\hline Local market & 1 & 0 & 0 & 0 & 0 & 1 & 5 & 5.00 & 16 \\
\hline Agrovet & 1 & 0 & 0 & 0 & 0 & 1 & 5 & 5.00 & 16 \\
\hline Catholic church & 0 & 1 & 0 & 0 & 0 & 1 & 4 & 4.00 & 20 \\
\hline
\end{tabular}

Total frequency is the number of farmers using the particular source who also rated it

Total scores are weighted scores calculated by multiplying the frequencies by the rating as follows; most important $=5$, important $=4$, neutral $=3$, less important $=2$, least important $=1$

Overall ranking was based on the total scores

Average score is the total score divided by total frequency and it shows the average rating of farmers using that particular source 


\subsection{Feeds and feed practices on the farm}

Table 20: Percentage of farmers with feed practices on farm and those aware of the technology but not implemented

\begin{tabular}{|c|c|c|c|c|c|}
\hline & Feeds and Practices & $\begin{array}{c}\% \text { of farmers aware } \\
\text { of technology } \\
(n=181)\end{array}$ & $\begin{array}{c}\text { No. with } \\
\text { technology }\end{array}$ & $\begin{array}{l}\% \text { of the sample } \\
\text { with technology } \\
\qquad(n=181)\end{array}$ & $\begin{array}{l}\text { \% of cases aware of } \\
\text { technology but not } \\
\text { implemented }\end{array}$ \\
\hline \multirow[t]{5}{*}{ Grasses } & Napier & 99.4 & 165 & 91.2 & 8.3 \\
\hline & Boma Rhodes & 75.1 & 78 & 43.1 & 32.0 \\
\hline & Columbus grass & 23.8 & 21 & 11.6 & 12.2 \\
\hline & Nandi setaria & 26 & 9 & 5.0 & 21.0 \\
\hline & Sudan grass & 4.4 & 3 & 1.7 & 2.7 \\
\hline \multirow{5}{*}{$\begin{array}{l}\text { Herbacious } \\
\text { legumes }\end{array}$} & Lucerne & 73.5 & 23 & 12.7 & 60.8 \\
\hline & Desmodium & 42 & 17 & 9.4 & 32.6 \\
\hline & Lupin & 9.9 & 5 & 2.8 & 7.1 \\
\hline & Purple vetch & 1.1 & 2 & 1.1 & 0 \\
\hline & Lablab & 2.2 & 1 & 0.6 & 1.6 \\
\hline Fodder shrubs & $\begin{array}{l}\text { Calliandra, Leuceana, Mulberry, } \\
\text { Tree lucerne, Sesbania }\end{array}$ & 67.5 & 60 & 33.1 & 34.4 \\
\hline \multirow{4}{*}{$\begin{array}{l}\text { Other fodder } \\
\text { crops }\end{array}$} & Oats & 63 & 65 & 36.5 & 26.5 \\
\hline & Sweet potato vines & 44.2 & 49 & 27.1 & 17.1 \\
\hline & Forage sorghum & 37 & 32 & 17.7 & 19.3 \\
\hline & Cow candy & 2.2 & 4 & 2.2 & 0 \\
\hline \multirow[t]{9}{*}{ Crop residues } & Maize stover dry & 42 & 66 & 36.5 & 5.5 \\
\hline & Maize stover green & 20.4 & 31 & 17.1 & 3.3 \\
\hline & Bean husks & 30.9 & 41 & 22.7 & 8.2 \\
\hline & Sunflower cakes & 21.5 & 13 & 7.2 & 14.3 \\
\hline & Wheat straws & 8.8 & 8 & 4.4 & 4.4 \\
\hline & Millet straws & 3.3 & 7 & 3.9 & -0.6 \\
\hline & Maize stover ground & 15.5 & 8 & 4.4 & 11.1 \\
\hline & Barley straws & 0.6 & 1 & 0.6 & 0 \\
\hline & Yellow maize & 0.6 & 1 & 0.6 & 0 \\
\hline \multirow[t]{5}{*}{ Feed Practices } & Silage making & 40.9 & 17 & 9.4 & 31.5 \\
\hline & Hay making & 24.9 & 14 & 7.2 & 17.7 \\
\hline & $\begin{array}{l}\text { Dairy meal/commercially mixed } \\
\text { concentrates }\end{array}$ & 19.9 & 13 & 7.7 & 12.2 \\
\hline & Home-made concentrates & 1.7 & 1 & 0.6 & 1.1 \\
\hline & Ration/feed formulation & 7.2 & 5 & 2.8 & 4.4 \\
\hline
\end{tabular}




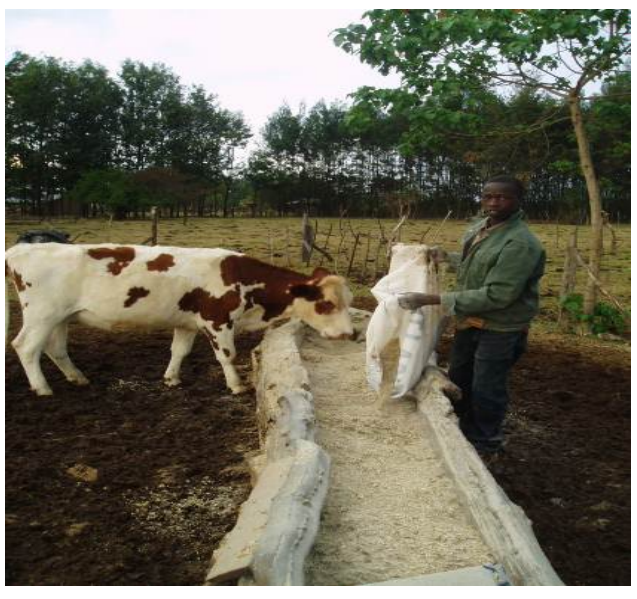

A heifer feeding on homemade concetrates in Kabiyet

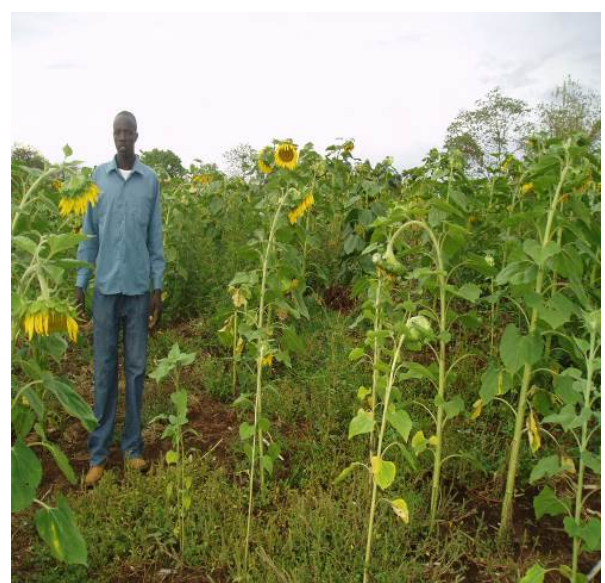

A farmer in his sunflower farm

Napier was the most common grass planted. 91.2 percent of the households in all the sites had Napier, 43.1 percent had Boma Rhodes and less than 2 percent had planted Sudan grass (Table 20). Among herbaceous legumes, 12.7 percent of farmers had planted lucerne on their farms while only 0.6 percent had lablab. Out of 67.5 percent of farmers who were aware of fodder shrubs, only about 33.1 percent had planted fodder shrubs on their farms with calliandra being the most common. Slightly less than 20 percent of the farmers had calliandra on their farms, while sesbania, leucaena, mulberry and tree lucerne were planted by less than 5 percent of farmers respectively. Among other fodder crops, oat was planted by and 17.7 percent had forage sorghum. Maize stover is a common crop residue among farmers in all the study sites. About 36.5 percent of respondents used dry maize stover while 17.1 percent used green maize stover. Other crop residues used by farmers included bean husks, sunflower cakes, among others (Table 20). Regarding feed practices, 9.4

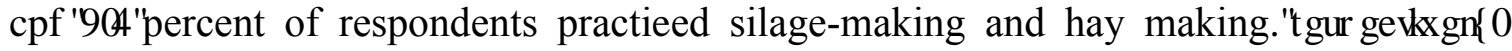
Other practices that farmers used included feed formulation and home-made concentrates $\square$ among others.

Disaggregating data by gender, Napier grass was the most grown grass by both male and female farmers, with slightly less than 90 percent of male farmers having it on their farms compared to over 90 percent of female farmers (Table 21). Boma Rhodes was the second most grown grass by both male and female farmers at 40.4 percent and 47.2 percent respectively. Among herbaceous fodder legumes, lucerne was the most grown by both male and female farmers, followed by desmodium although the proportions were less than 20 percent. Reasons are explored in the next section. About 38D percent of male farmers had planted fodder shrubs as compared to about 25 percent of female farmers. In regards to other fodder crops, a higher proportion of male farmers had planted oats 
Table 21: Feeds and feed practices on the farm across gender

\begin{tabular}{|c|c|c|c|}
\hline & Feeds and practices & $\begin{array}{c}\% \text { of male } \\
\text { farmers }(n=109)\end{array}$ & $\begin{array}{c}\% \text { of female farmers } \\
=(n=72)\end{array}$ \\
\hline \multirow[t]{5}{*}{ Grasses } & Napier & 88.9 & 94.4 \\
\hline & Boma Rhodes & 40.4 & 47.2 \\
\hline & Nandi setaria & 6.4 & 2.8 \\
\hline & Columbus grass & 11.9 & 11.1 \\
\hline & Sudan grass & 0 & 4.2 \\
\hline \multirow[t]{4}{*}{ Herbaceous legumes } & Lucerne & 13.8 & 11.1 \\
\hline & Desmodium & 10.1 & 8.3 \\
\hline & Lupin & 3.7 & 1.4 \\
\hline & Purple vetch & 0 & 2.8 \\
\hline Fodder shrubs & $\begin{array}{l}\text { Calliandra, Mulbery, Sesbania, } \\
\text { Tree Lucerne, Leucaena }\end{array}$ & 38.5 & 25 \\
\hline \multirow[t]{3}{*}{ Other fodder crops } & Oats & 41.3 & 27.8 \\
\hline & Sweet potato vines & 23.9 & 31.9 \\
\hline & Forage sorghum & 16.5 & 19.4 \\
\hline \multirow[t]{8}{*}{ Crop residues } & Maize stover dry & 38.5 & 33.3 \\
\hline & Maize stover green & 18.3 & 15.3 \\
\hline & Bean husks & 19.3 & 27.8 \\
\hline & Sunflower cakes & 8.3 & 5.6 \\
\hline & Wheat straws & 5.5 & 2.8 \\
\hline & Millet straws & 0.9 & 6.9 \\
\hline & Maize ground & 2.8 & 6.9 \\
\hline & Barley straws & 0.9 & 0 \\
\hline \multirow[t]{7}{*}{ Feed practices } & Silage & 11 & 6.9 \\
\hline & Hay & 8.3 & 6.9 \\
\hline & $\begin{array}{l}\text { Dairy meal/commercial } \\
\text { concentrates }\end{array}$ & 9.1 & 4.2 \\
\hline & Feed/ration formulation & 4.6 & 0 \\
\hline & Mineral supplementation & 11.0 & 00 \\
\hline & Pasture improvement & 3.7 & 5.6 \\
\hline & Homemade concentrates & 0.9 & 0.0 \\
\hline
\end{tabular}


compared to females. In contrast to this, a higher proportion of women farmers had planted sweet potato vines and forage sorghum compared to male farmers. This could be because these two crops are dual purpose - used for human consumption and as livestock feed. Among crop residues, dry maize stover was the most widely used by 38.5 percent of male and 33.3 percent of female farmers. A higher proportion of male farmers had implemented different feed practices compared to female farmers.

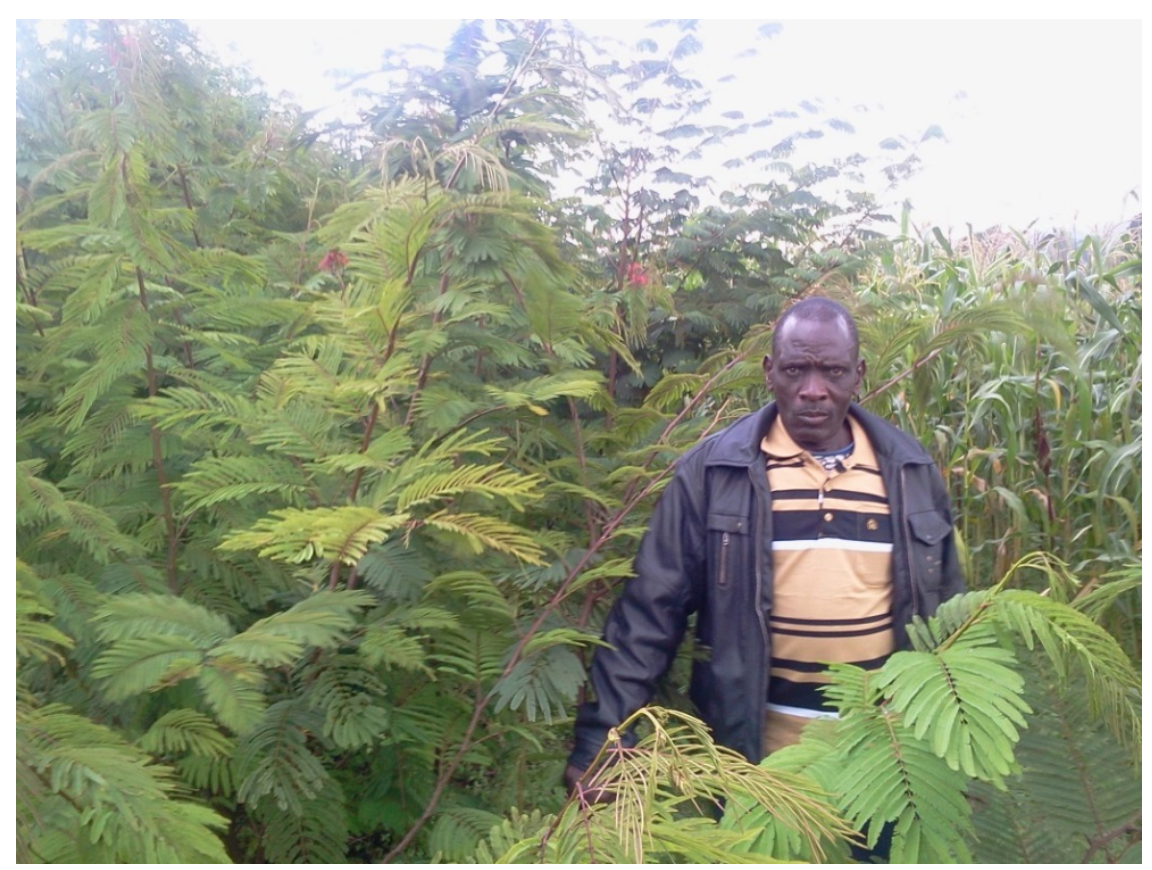

A farmer in his calliandra farm

\section{Feed practices on-farm across POs}

Napier grass was the most common grass across all the sites with over 90 percent of respondents having it on their farms in all POs except in Taragoon and Sirikwa (Table 22). All farmers interviewed in Olenguruone had planted Napier grass. Boma Rhodes was also common across all the study sites. Sudan grass was grown by less than 10 percent of farmers in Taragoon, Olkalou and Sot POs. Among the herbaceous legumes, lucerne was available on farms across all the sites except Olenguruone. Desmodium was also planted by farmers in all sites except Metkei and Olenguruone. Lablab was only planted by farmers interviewed in Kabiyet while purple vetch was only found in Olkalou. Lupin was only found in Metkei. Among fodder shrubs, calliandra was available on farms across all the sites with 47 percent of farmers having it in Kabiyet, 33 percent in Cherobu and 35 percent in Sot. Tree lucerne was only found in Metkei. Among other fodder crops, 90 percent of farmers had oats in Metkei, 71 percent in Olkalou and 75 percent in Olenguruone - these sites all fall under the UH zones. This could be attributed to oats 
thriving well in the highlands. In Taragoon which falls under the lower highlands, 57 percent of the farmers plant oats. Sweet potato vines were planted by farmers across all the sites except in Olenguruone and Taragoon. Among crop residues, dry maize stover was used by farmers across all the sites (Table 22). Wheat straw was used in three sites; Sirikwa, Taragoon and Siongiroi while barley straw was used in only Taragoon. Among feed practices, silage-making was practiced in only two sites, Taragoon, Metkei and Olkalou.

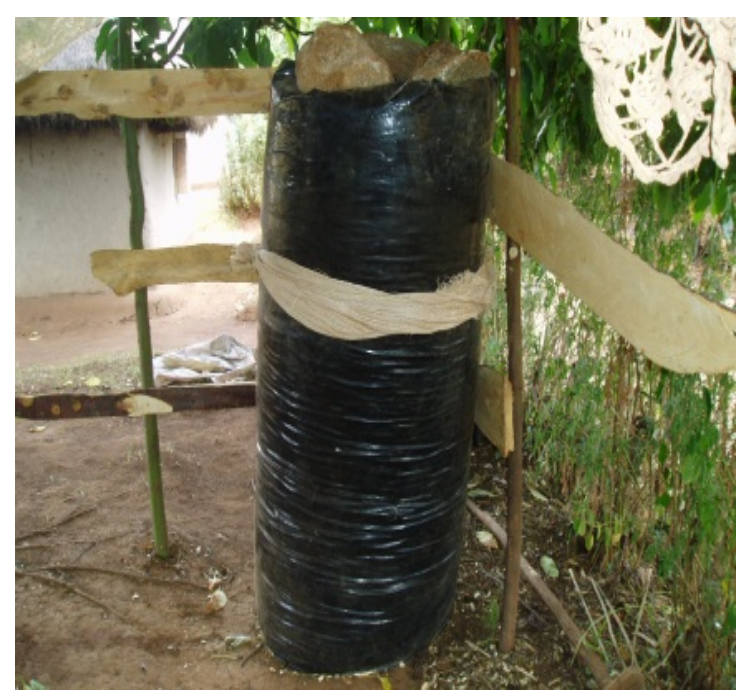

Tube silage in south Rift Valley

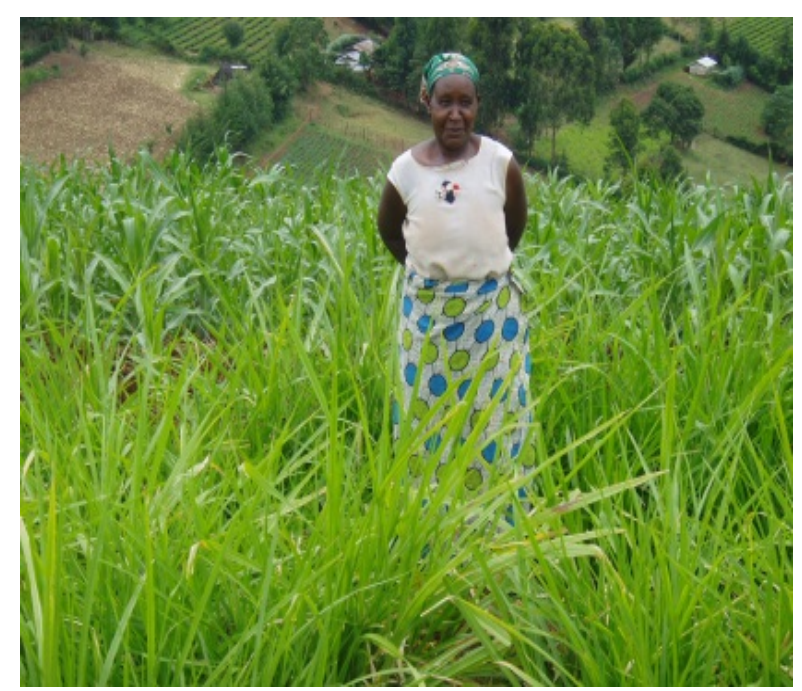

A farmer in her Napier grass farm in south Rift Valley 
Table 22: Percentage of farmers with feeds and feed practices on farm per PO

\begin{tabular}{|c|c|c|c|c|c|c|c|c|c|c|}
\hline & $\begin{array}{l}\text { Feeds and feed } \\
\text { practices }\end{array}$ & $\begin{array}{c}\text { Kabiyet } \\
(n=19)\end{array}$ & $\begin{array}{c}\text { Sirikwa } \\
(n=18)\end{array}$ & $\begin{array}{c}\text { Taragoon } \\
(n=21)\end{array}$ & $\begin{array}{l}\text { Metkei } \\
(n=29)\end{array}$ & $\begin{array}{c}\text { Cherobu } \\
(n=12)\end{array}$ & $\begin{array}{c}\text { Olkalou } \\
(n=21)\end{array}$ & $\begin{array}{c}\text { Sot } \\
(n=26)\end{array}$ & $\begin{array}{c}\text { Siongiroi } \\
(n=23)\end{array}$ & $\begin{array}{c}\text { Olenguruone } \\
(n=12)\end{array}$ \\
\hline \multirow[t]{5}{*}{ Grasses } & Napier & 95 & 89 & 71 & 97 & 92 & 90 & 96 & 91 & 100 \\
\hline & Boma Rhodes & 68 & 67 & 29 & 3 & 50 & 19 & 54 & 91 & 8 \\
\hline & Nandi setaria & 0 & 0 & 0 & 3 & 8 & 0 & 4 & 9 & 42 \\
\hline & Columbus grass & 0 & 0 & 5 & 0 & 8 & 14 & 0 & 65 & 8 \\
\hline & Sudan grass & 0 & 0 & 5 & 0 & 0 & 5 & 4 & 0 & 0 \\
\hline \multirow[t]{5}{*}{ Herbaceous legumes } & Lucerne & 5 & 6 & 14 & 14 & 8 & 14 & 15 & 26 & 0 \\
\hline & Desmodium & 26 & 6 & 5 & 0 & 8 & 10 & 15 & 13 & 0 \\
\hline & Lablab & 5 & 0 & 0 & 0 & 0 & 0 & 0 & 0 & 0 \\
\hline & Purple vetch & 0 & 0 & 0 & 0 & 0 & 10 & 0 & 0 & 0 \\
\hline & Lupin & 0 & 0 & 0 & 17 & 0 & 0 & 0 & 0 & 0 \\
\hline \multirow[t]{5}{*}{ Fodder shrubs } & Calliandra & 47 & 6 & 5 & 3 & 33 & 14 & 35 & 26 & 8 \\
\hline & Sesbania & 0 & 6 & 0 & 7 & 17 & 0 & 8 & 0 & 17 \\
\hline & Leucaena & 0 & 6 & 0 & 0 & 8 & 0 & 4 & 9 & 0 \\
\hline & Mulberry & 16 & 0 & 0 & 7 & 8 & 0 & 0 & 0 & 0 \\
\hline & Tree lucerne & 0 & 0 & 0 & 17 & 0 & 0 & 0 & 0 & 0 \\
\hline \multirow[t]{3}{*}{ Other fodder crops } & Oats & 0 & 6 & 57 & 90 & 0 & 71 & 0 & 9 & 75 \\
\hline & Forage sorghum & 21 & 28 & 5 & 0 & 33 & 29 & 38 & 9 & 0 \\
\hline & Sweet potato vines & 53 & 11 & 0 & 3 & 42 & 5 & 69 & 52 & 0 \\
\hline \multirow[t]{2}{*}{ Crop residues } & Maize stover green & 11 & 56 & 31 & 0 & 14 & 4 & 4 & 17 & 8 \\
\hline & Maize stover dry & 5 & 44 & 67 & 24 & 33 & 76 & 31 & 22 & 35 \\
\hline
\end{tabular}




\begin{tabular}{|c|c|c|c|c|c|c|c|c|c|c|}
\hline & Banana pseudo stems & 0 & 11 & 17 & 5 & 15 & 5 & 15 & 26 & 8 \\
\hline & Sunflower cakes & 5 & 22 & 5 & 21 & 0 & 0 & 0 & 0 & 8 \\
\hline & Wheat straws & 0 & 6 & 24 & 0 & 0 & 0 & 0 & 9 & 0 \\
\hline & Barley straws & 0 & 0 & 5 & 0 & 0 & 0 & 0 & 0 & 0 \\
\hline & Millet straws & 0 & 33 & 0 & 0 & 0 & 0 & 0 & 0 & 0 \\
\hline & Bean husks & 0 & 50 & 43 & 17 & 0 & 0 & 33 & 35 & 0 \\
\hline \multirow[t]{5}{*}{ Feed practices } & Silage-making & 0 & 0 & 38 & 7 & 0 & 33 & 0 & 0 & 0 \\
\hline & Hay making & 0 & 17 & 23 & 3 & 8 & 19 & 0 & 0 & 0 \\
\hline & $\begin{array}{l}\text { Commercially mixed } \\
\text { concentrates }\end{array}$ & 0 & 0 & 10 & 21 & 0 & 4 & 0 & 17 & 17 \\
\hline & Feed formulation & 0 & 0 & 24 & 0 & 0 & 0 & 0 & 0 & 0 \\
\hline & Pasture improvement & 0 & 0 & 14 & 7 & 0 & 0 & 0 & 9 & 8 \\
\hline
\end{tabular}

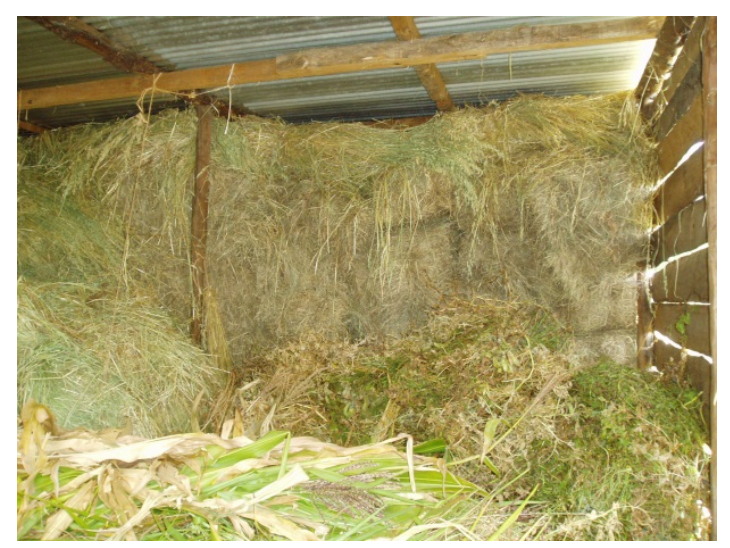

Hay and green maize stover in a store 


\section{Reasons for planting livestock feeds}

Livestock feeding was mentioned by farmers as the main reason for planting grasses. Apart from livestock feeding, other reasons for planting grasses included drought resistance for Napier, and increase in animal productivity for Boma Rhodes and Columbus grass (Table 23)

Table 23: Reasons for planting grasses

\begin{tabular}{|c|c|c|c|c|c|}
\hline Reason & $\begin{array}{c}\text { Napier } \\
\text { grass } \\
(n=164)\end{array}$ & $\begin{array}{l}\text { Boma Rhodes } \\
(\mathrm{n}=77)\end{array}$ & $\begin{array}{c}\text { Columbus } \\
\text { grass } \\
(\mathrm{n}=21)\end{array}$ & $\begin{array}{c}\text { Nandi } \\
\text { setaria } \\
(\mathrm{n}=8)\end{array}$ & Giant setaria $(n=3)$ \\
\hline & \multicolumn{5}{|c|}{ Percentage of farmers } \\
\hline Livestock feeding & 43.9 & 37.6 & 23.6 & 37.5 & 33.3 \\
\hline Drought resistance & 15.2 & 2.5 & 0 & 0 & 0.0 \\
\hline Supplement & 7.3 & 3.9 & 9.5 & 12.5 & 0.0 \\
\hline Increases animal production & 7.3 & 15.6 & 0 & 12.5 & 33.3 \\
\hline For dry spell & 4.9 & 3.9 & 0 & 12.5 & 0.0 \\
\hline Silage-making & 3.7 & 0.0 & 4.8 & 0 & 0.0 \\
\hline Grows fast & 3.0 & 2.5 & 10 & 0 & 0.0 \\
\hline Bulking & 3.0 & 1.3 & 0 & 0 & 0.0 \\
\hline Easy to grow & 1.8 & 1.3 & 0 & 0 & 0.0 \\
\hline Easy to manage & 1.8 & 0.0 & 0 & 12.5 & 0.0 \\
\hline High palatability & 1.2 & 1.3 & 0 & 0 & 0.0 \\
\hline $\begin{array}{l}\begin{array}{l}\text { Availability of planting } \\
\text { material }\end{array} \\
\end{array}$ & 0.6 & 0.0 & 0 & 0 & 0.0 \\
\hline Low maintenance & 0.6 & 0.0 & 0 & 0 & 0.0 \\
\hline Ability for regrowth & 0.6 & 0.0 & 0 & 0 & 0.0 \\
\hline Substitute for Kikuyu grass & 0.6 & 0.0 & 0 & 0 & 0.0 \\
\hline High yielding & 0.6 & 2.5 & 9.5 & 0 & 33.3 \\
\hline Evergreen & 0.6 & 0.0 & 0 & 0 & 0.0 \\
\hline Control soil erosion & 0.6 & 0.0 & 0 & 0 & 0.0 \\
\hline Hay making & 0.0 & 7.8 & 0 & 0 & 0.0 \\
\hline High protein & 0.0 & 1.3 & 28.6 & 0 & 0.0 \\
\hline Easily conserved & 0.0 & 15.6 & 4.8 & 0 & 0.0 \\
\hline Very nutritive & 0.0 & 1.3 & 4.8 & 0 & 0.0 \\
\hline Multiple harvests & 0.0 & 1.3 & 0 & 0 & 0.0 \\
\hline
\end{tabular}

Oat was mainly planted for animal feeding while about 13.8 percent indicated that it also increased animal productivity. About a third of farmers grew forage sorghum for livestock feeding while about 23.3 percent planted it because they used it as a supplement feed for livestock. In contrast to oat and forage sorghum, sweet potato vines were mainly grown because of their dual-purpose ability (for human consumption and livestock feed) followed by the ability to increase animal productivity and high protein content (Table 24). 
Table 24: Reasons for planting oats, forage sorghum and sweet potato vines

\begin{tabular}{|c|c|c|c|}
\hline Reasons & Oats $(n=65)$ & $\begin{array}{l}\text { Forage sorghum } \\
\qquad(\mathrm{n}=30)\end{array}$ & $\begin{array}{l}\text { Sweet potato } \\
\text { vines } n=49 \text { ) }\end{array}$ \\
\hline & \multicolumn{3}{|c|}{ Percentage of farmers } \\
\hline Livestock feeding & 32.3 & 33.3 & 16.3 \\
\hline Supplement & 7.6 & 23.3 & 0.0 \\
\hline Hay making & 3.1 & 0.0 & 0.0 \\
\hline Silage-making & 0.0 & 6.6 & 0.0 \\
\hline High protein & 0.0 & 3.3 & 18.4 \\
\hline Increases animal productivity & 13.8 & 3.3 & 18.4 \\
\hline Drought resistance & 0.0 & 6.6 & 0.0 \\
\hline Easy to grow & 4.6 & 0.0 & 0.0 \\
\hline Availability of planting material & 1.5 & 0.0 & 0.0 \\
\hline Low maintenance & 1.5 & 3.3 & 0.0 \\
\hline Dual purpose & 0.0 & 16.7 & 32.7 \\
\hline Grows fast & 7.6 & 3.3 & 0.0 \\
\hline Easily conserved & 7.6 & 0.0 & 0.0 \\
\hline High palatability & 0.0 & 0.0 & 2.0 \\
\hline Substitute to concentrates & 0.0 & 0.0 & 2.0 \\
\hline Very nutritive & 1.5 & 0.0 & 4.1 \\
\hline Easy to manage & 3.1 & 0.0 & 0.0 \\
\hline Seeds available & 3.1 & 0.0 & 0.0 \\
\hline Reduce expenses for buying feeds & 1.5 & 0.0 & 0.0 \\
\hline
\end{tabular}

Apart from livestock feeding, a third of farmers planted lucerne because of its high protein content while desmodium was planted also as a livestock feed supplement. Apart from livestock feeding, the other reasons for planting fodder shrubs was because of their high protein content (Table 25). 
Table 25: Reasons for planting herbaceous fodder legumes and shrubs

\begin{tabular}{|c|c|c|c|c|c|c|c|}
\hline & $\begin{array}{l}\text { Lucerne } \\
(n=23)\end{array}$ & $\begin{array}{l}\text { Desmodium } \\
\quad(n=17)\end{array}$ & $\begin{array}{l}\text { Lupin } \\
(n=5)\end{array}$ & $\begin{array}{l}\text { Calliandra } \\
(n=34)\end{array}$ & $\begin{array}{c}\text { Sesbania } \\
(n=9)\end{array}$ & $\begin{array}{c}\text { Mulberry } \\
(n=6)\end{array}$ & $\begin{array}{l}\text { Tree } \\
\text { lucerne } \\
(n=5)\end{array}$ \\
\hline Livestock feeding & 43.5 & 35.3 & 20.0 & 50.0 & 44.4 & 33.3 & 0.0 \\
\hline High protein & 30.4 & 11.8 & 20.0 & 26.5 & 22.2 & 33.3 & 40.0 \\
\hline Supplement & 13.0 & 23.5 & 20.0 & 5.9 & 11.1 & 16.7 & 0.0 \\
\hline Grows fast & 4.3 & 0.0 & 0.0 & 2.9 & 0.0 & 0.0 & 0.0 \\
\hline Easily conserved & 4.3 & 5.9 & 0.0 & 0.0 & 0.0 & 0.0 & 0.0 \\
\hline Very nutritive & 4.3 & 11.8 & 0.0 & 0.0 & 0.0 & 0.0 & 0.0 \\
\hline $\begin{array}{l}\text { Improves animal } \\
\text { production }\end{array}$ & 0.0 & 5.9 & 20.0 & 2.9 & 0.0 & 0.0 & 40.0 \\
\hline Low maintenance & 0.0 & 0.0 & 0.0 & 0.0 & 11.1 & 0.0 & 0.0 \\
\hline For dry spell & 0.0 & 5.9 & 0.0 & 0.0 & 0.0 & 0.0 & 20.0 \\
\hline High yielding & 0.0 & 0.0 & 0.0 & 2.9 & 0.0 & 0.0 & 0.0 \\
\hline $\begin{array}{l}\text { Substitute to } \\
\text { concentrates }\end{array}$ & 0.0 & 0.0 & 0.0 & 5.9 & 0.0 & 0.0 & 0.0 \\
\hline Easy to manage & 0.0 & 0.0 & 0.0 & 2.9 & 0.0 & 0.0 & 0.0 \\
\hline $\begin{array}{l}\text { Soil fertility } \\
\text { improvement }\end{array}$ & 0.0 & 0.0 & 20.0 & 0.0 & 0.0 & 0.0 & 0.0 \\
\hline
\end{tabular}

\section{Sources of seeds and planting materials for various feeds and feed practices}

Fellow farmers as a source was cited by more farmers interviewed than any other source for obtaining Napier grass planting material and Nandi setaria seed. This was followed by neighbours. Farmers mainly obtained seeds for Boma Rhodes and Columbus grass from commercial agrovets (Table 26). 
Table 26: Main sources of seeds for grasses

\begin{tabular}{|c|c|c|c|c|}
\hline & $\begin{array}{l}\text { Napier } \\
(\mathrm{N}=153)\end{array}$ & $\begin{array}{c}\text { Boma } \\
\text { Rhodes } \\
(\mathrm{N}=76)\end{array}$ & $\begin{array}{l}\text { Columbus } \\
\text { grass } \\
(\mathrm{N}=21)\end{array}$ & $\begin{array}{l}\text { Nandi } \\
\text { setaria }(\mathrm{N}=8)\end{array}$ \\
\hline & \multicolumn{4}{|c|}{$\%$ of farmers } \\
\hline Fellow farmer & 44.4 & 1.3 & 9.5 & 62.5 \\
\hline Neighbour & 35.2 & 10.5 & 0 & 25.0 \\
\hline Friend & 4.6 & 1.3 & 4.7 & 0.0 \\
\hline Farmer trainer & 3.9 & 0.0 & 9.5 & 0.0 \\
\hline On farm & 2.6 & 0.0 & 0 & 0.0 \\
\hline KARI & 2.6 & 0.0 & 4.7 & 0.0 \\
\hline Commercial agrovet & 1.9 & 47.3 & 52.3 & 0.0 \\
\hline Ministry of Agriculture/Livestock & 1.9 & 3.9 & 0 & 0.0 \\
\hline EADD & 0.6 & 2.6 & 4.7 & 0.0 \\
\hline Kenya Seed company & 0.6 & 9.2 & 4.7 & 12.5 \\
\hline KFA & 0.6 & 10.5 & 4.7 & 0.0 \\
\hline Model farmer & 0.6 & 0.0 & 0 & 0.0 \\
\hline Stockist & 0 & 0 & 0 & 0.0 \\
\hline ICRAF & 0 & 1.3 & 0 & 0.0 \\
\hline Local market & 0 & 9.2 & 4.7 & 0.0 \\
\hline CESPs & 0 & 0.0 & 0 & 0.0 \\
\hline ASK show & 0 & 2.6 & 0 & 0.0 \\
\hline
\end{tabular}


As regards to herbaceous fodder legumes such as lucerne, a majority of farmers obtained seed from agrovets followed by Kenya Farmers Association (Table 27). The most cited source for desmodium was neigbours and the EADD project (Table 27). Other sources included stockists and fellow farmers. About 46.8 percent of farmers obtained oats seed from commercial agrovets, while a few farmers bought from stockists (20.3\%). About a third of farmers got sweet potato vines planting material from other farmers and neigbours. Other important sources included EADD and ICRAF.

Table 27: Sources of seed/planting material for lucerne, desmodium, oats and sweet potato vines

\begin{tabular}{|l|c|c|r|r|}
\hline & Lucerne (n=22) & $\begin{array}{l}\text { Desmodium } \\
(\mathrm{n}=16)\end{array}$ & \multicolumn{1}{|c|}{$\begin{array}{l}\text { Oats } \\
(\mathrm{n}=64)\end{array}$} & $\begin{array}{l}\text { Sweet } \\
\text { votato } \\
(\mathrm{n}=47)\end{array}$ \\
\hline & \multicolumn{3}{|c|}{ Percentage of farmers } \\
\hline Agrovet & 45.5 & 0 & 46.8 & 2.1 \\
\hline KFA & 22.7 & 6.3 & 3.1 & 0 \\
\hline Stockist & 9.0 & 12.5 & 20.3 & 0 \\
\hline ASK show & 4.5 & 6.3 & 0 & 0 \\
\hline EADD & 0 & 25 & 0 & 19.1 \\
\hline Kenya Seed & 4.5 & 0 & 12.5 & 0 \\
Company & 4.5 & 6.3 & 0 & 0 \\
\hline MOA & 0 & 25 & 1.5 & 29.7 \\
\hline Neighbour & 4.5 & 12.5 & 15.6 & 31.9 \\
\hline Fellow farmer & 0 & 0 & 0 & 0 \\
\hline On farm & 0 & 6.3 & 0 & 0 \\
\hline CESPS & 0 & 0 & 0 & 2.1 \\
\hline Model farmer & 4.5 & 0 & 0 & 10.6 \\
\hline ICRAF & 0 & 0 & 1.5 & 2.1 \\
\hline Friend & 0 & 0 & 0 & 2.1 \\
\hline Farmer group & & &
\end{tabular}


Table 28: Sources of planting material for fodder shrubs

\begin{tabular}{|l|r|r|r|r|r|r|}
\hline & $\begin{array}{l}\text { Calliandra } \\
(\mathrm{n}=34)\end{array}$ & $\begin{array}{l}\text { Mulberry } \\
(\mathrm{n}=4)\end{array}$ & $\begin{array}{l}\text { Tree } \\
\text { lucerne } \\
(\mathrm{n}=5)\end{array}$ & $\begin{array}{l}\text { Sesbania } \\
(\mathrm{n}=9)\end{array}$ & $\begin{array}{l}\text { Leucaena } \\
(\mathrm{n}=4)\end{array}$ \\
\hline Agrovet & \multicolumn{7}{|c|}{ Percentage of farmers } \\
\hline EADD & 11.8 & 0 & 40 & 0 & 0 \\
\hline ICRAF & 23.5 & 0 & 0 & 22.2 & 25 \\
\hline Neighbour & 14.7 & 0 & 0 & 0 & 0 \\
\hline Fellow farmers & 5.8 & 0 & 0 & 33.3 & 0 \\
\hline Private nursery & 5.8 & 50 & 40 & 11.1 & 0 \\
\hline Farmer trainer & 2.9 & 50 & 0 & 0 & 25 \\
\hline MOL/MOA & 5.8 & 0 & 0 & 11.1 & 50 \\
\hline KFA & 0 & 0 & 0 & 0 & 0 \\
\hline Market & 11.7 & 0 & 0 & 0 & 0 \\
\hline Others & 9.2 & 0 & 20 & 33.3 & 0 \\
\hline
\end{tabular}

Farmers obtained calliandra seeds/seedlings mainly from the EADD project and ICRAF, and others bought from private nurseries and the market (Table 28). Other sources were MOA and MOL which have since been combined to form the Ministry of Agriculture, Livestock and Fisheries development (MOLFD) and fellow farmers. Mulberry had been planted by a few farmers who obtained planting material from farmer trainers and fellow farmers. Farmers obtained sesbania material from neighbours and the EADD project. Tree lucerne seeds were obtained from agrovets (40\%) and fellow farmers. Leuceana seeds were obtained mainly from MOLFD, the EADD project and private nurseries. 


\section{Niches where improved livestock feed is planted}

The most common niche for planting grasses is the cropland. Planting grasses in the cropland offers protection from animals. Fodder shrubs are planted either on the boundary or in the cropland (Table 29).

Table 29: Niches where livestock feeds are planted

\begin{tabular}{|c|c|c|c|c|c|}
\hline \multicolumn{6}{|l|}{ Niche } \\
\hline & & \multirow{2}{*}{$\mathrm{N}$} & Boundary & Cropland & Grazing land \\
\hline & & & \multicolumn{3}{|c|}{ Percentage of $n$} \\
\hline \multirow[t]{4}{*}{ Grasses } & Napier grass & 160 & 20.7 & 81.2 & 1.8 \\
\hline & Boma Rhodes & 75 & 1.3 & 97.3 & 1.3 \\
\hline & Columbus grass & 20 & 0.0 & 100.0 & 0.0 \\
\hline & Nandi setaria & 9 & 11.1 & 88.8 & 0.0 \\
\hline \multirow[t]{4}{*}{ Fodder shrubs } & Leuceana & 5 & 100.0 & 0.0 & 0.0 \\
\hline & Calliandra & 35 & 74.2 & 25.7 & 0.0 \\
\hline & Tree lucerne & 5 & 80.0 & 20.0 & 0.0 \\
\hline & Mulberry & 6 & 33.3 & 66.7 & 0.0 \\
\hline \multirow[t]{2}{*}{ Herbaceous legumes } & Desmodium & 17 & 11.8 & 88.2 & 0.0 \\
\hline & Lucerne & 21 & 0.0 & 100.0 & 0.0 \\
\hline \multirow[t]{4}{*}{ Other fodder crops } & Oats & 65 & 6.1 & 93.9 & 0.0 \\
\hline & Sweet potato vines & 47 & 0.0 & 100.0 & 0.0 \\
\hline & Forage sorghum & 31 & 0.0 & 100.0 & 0.0 \\
\hline & Sunflower & 13 & 23.1 & 76.9 & 0.0 \\
\hline
\end{tabular}

$\mathrm{n}=$ total number of farmers that responded to the question

Calliandra, leuceana and tree lucerne are mainly planted along the boundary while mulberry is mostly found in the cropland. Herbaceous fodder legumes and other fodder crops such as oats, sweet potato vines, sunflower and forage sorghum are mostly found in the cropland

\section{Mean acreage of feed practices/number of trees per household}

Among grasses, Boma Rhodes had the highest acreage of 0.8 followed by Napier grass (Table 30). Among fodder shrubs, tree lucerne had the highest mean number of trees, followed by calliandra. It is however important to note that tree lucerne was planted by 
five farmers only with three of them having between 51-100 trees (Table 31). Among herbaceous legumes, lucerne had the highest mean acreage of 0.9 followed by purple vetch that was planted by two farmers.

Table 30: Mean acreage of feed practices/number of trees per household

\begin{tabular}{|c|c|c|c|c|}
\hline & & $\mathrm{n}$ & $\begin{array}{l}\text { Mean acreage/no. of } \\
\text { trees }\end{array}$ & $\begin{array}{l}\text { Standard } \\
\text { deviatio }\end{array}$ \\
\hline \multirow[t]{5}{*}{ Grasses } & Napier grass & 157 & 0.5 & 0.6 \\
\hline & Boma Rhodes & 78 & 0.8 & 1.0 \\
\hline & Columbus grass & 21 & 0.3 & 0.4 \\
\hline & Nandi setaria & 8 & 0.2 & 0.1 \\
\hline & Giant setaria & 3 & 0.2 & 0.1 \\
\hline \multirow[t]{5}{*}{ Fodder shrubs } & Leuceana & 5 & $* 24.0$ & 23.9 \\
\hline & Calliandra & 33 & $* 69.6$ & 128.6 \\
\hline & Tree lucerne & 5 & $* 80.4$ & 54.5 \\
\hline & Mulberry & 3 & $* 5.3$ & 4.5 \\
\hline & Sesbania & 9 & $* 8.9$ & 9.9 \\
\hline \multirow[t]{3}{*}{ Herbaceous legumes } & Desmodium & 17 & 0.1 & 0.1 \\
\hline & Purple vetch & 2 & 0.8 & 0.4 \\
\hline & Lucerne & 21 & 0.9 & 2.3 \\
\hline \multirow[t]{5}{*}{ Other fodder crops } & Oats & 64 & 0.8 & 1.0 \\
\hline & Sweet potato vines & 49 & 0.2 & 0.2 \\
\hline & Forage sorghum & 32 & 0.2 & 0.2 \\
\hline & Edible cana & 1 & 0.1 & \\
\hline & Sunflower & 12 & $* 45.3$ & 105.7 \\
\hline
\end{tabular}

$n=$ total number of farmers that responded to the question

*Mean number of plants/trees

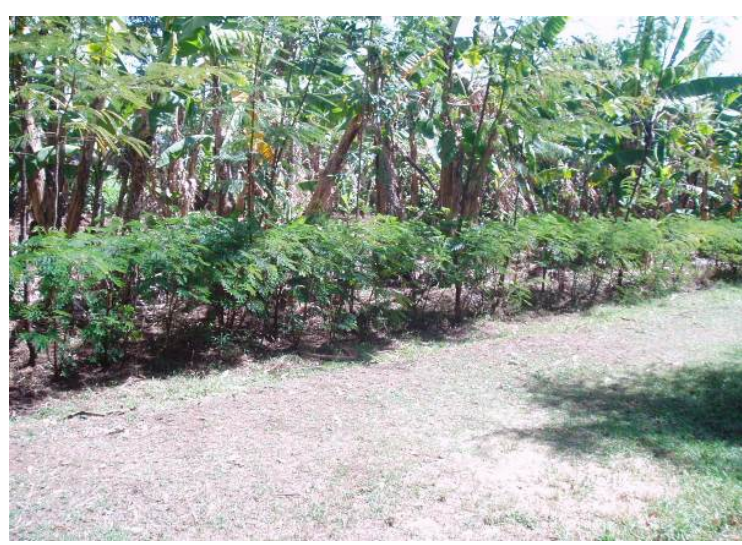

Calliandra hedge (Kapcheno, Riftvalley)

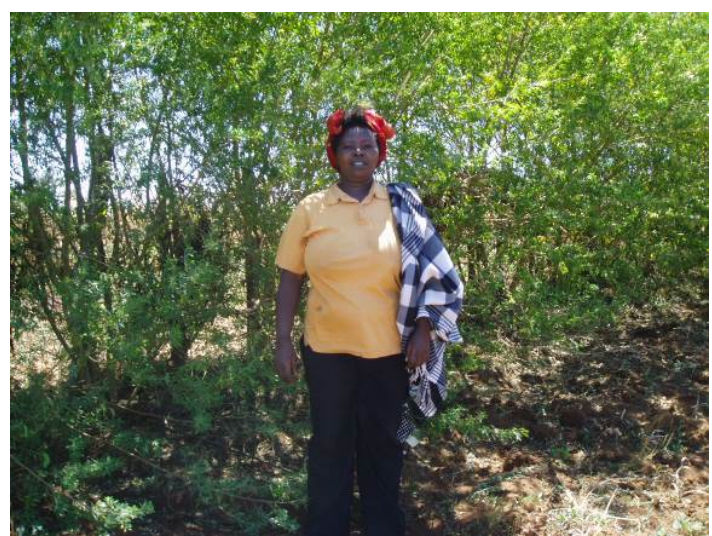

Tree lucerne in a hedge (Central Kenya) 
Table 31: Frequency showing number of farmers and number of trees

\begin{tabular}{|l|r|r|r|r|r|}
\hline No. of trees & Leuceana & Calliandra & Sesbania & Mulberry & $\begin{array}{c}\text { Tree } \\
\text { lucerne }\end{array}$ \\
\hline & \multicolumn{5}{|c|}{ Number of farmers } \\
\hline $1.00-10.00$ & 3 & 10 & 7 & 3 & 1 \\
\hline $11.00-50.00$ & 2 & 16 & 2 & 0 & 0 \\
\hline $51-100$ & 0 & 2 & 0 & 0 & 3 \\
\hline $101-150$ & 0 & 0 & 0 & 0 & 1 \\
\hline $151-200$ & 0 & 3 & 0 & 0 & 0 \\
\hline 500 & 0 & 1 & 0 & 0 & 0 \\
\hline 538.00 & 0 & 1 & 0 & 0 & 0 \\
\hline Total & 5 & 33 & 9 & 3 & 5 \\
\hline
\end{tabular}

\subsection{Livestock feed preferences}

\section{Reasons why farmers prefer different types of feeds}

Napier grass was the most preferred feed overall, followed by Boma Rhodes, maize stover dry, lucerne and oats (Table 32). Reasons why farmers preferred Napier grass included its drought resistant ability, high nutrient content, ability to increase milk production and its fast growth (Table 33). On the other hand, Boma Rhodes was preferred because it has the ability to increase milk production (and its high growth rate. 
Table 32: Farmers' preferences about livestock feeds/feed practices

\begin{tabular}{|c|c|c|c|c|c|c|c|c|c|}
\hline \multirow{3}{*}{ Feed/feed practice } & $\begin{array}{l}\text { Most } \\
\text { preferred }\end{array}$ & Preferred & Neutral & $\begin{array}{l}\text { Less } \\
\text { preferred }\end{array}$ & $\begin{array}{l}\text { Least } \\
\text { preferred }\end{array}$ & $\begin{array}{l}\text { Total } \\
\text { frequency }\end{array}$ & Total score & $\begin{array}{l}\text { Average } \\
\text { score }\end{array}$ & Overall Rank \\
\hline & 5 & 4 & 3 & 2 & 1 & & & & \\
\hline & \multicolumn{5}{|c|}{ Percentage of farmers } & & & & \\
\hline Napier & 58.79 & 20 & 9.09 & 4.85 & 7.27 & 165 & 690 & 4.18 & 1 \\
\hline Boma Rhodes & 72.04 & 11.83 & 5.38 & 2.15 & 8.6 & 93 & 406 & 4.37 & 2 \\
\hline Maize stover (dry) & 45.28 & 16.98 & 18.87 & 5.66 & 13.21 & 106 & 398 & 3.75 & 3 \\
\hline Lucerne & 57.14 & 11.9 & 11.9 & 7.14 & 11.9 & 42 & 166 & 3.95 & 4 \\
\hline Oats & 71.43 & 12.7 & 4.76 & 4.76 & 6.35 & 63 & 225 & 3.57 & 5 \\
\hline Mineral supplement & 75 & 9.09 & 6.82 & 4.55 & 4.55 & 44 & 195 & 4.43 & 6 \\
\hline Maize stalk (green) & 54.17 & 14.58 & 8.33 & 6.25 & 16.67 & 48 & 184 & 3.83 & 7 \\
\hline Wheat-straw & 80.49 & 4.88 & 0 & 2.44 & 12.2 & 41 & 180 & 4.39 & 8 \\
\hline Other crop residues & 75 & 9.38 & 3.13 & 0 & 12.5 & 32 & 139 & 4.34 & 9 \\
\hline Silage & 66.67 & 6.06 & 0 & 6.06 & 21.21 & 33 & 129 & 3.91 & 10 \\
\hline Forage sorghum & 37.5 & 9.38 & 25 & 12.5 & 15.63 & 32 & 117 & 3.66 & 11 \\
\hline Calliandra & 37.04 & 18.52 & 14.81 & 18.52 & 11.11 & 27 & 95 & 3.52 & 12 \\
\hline Columbus grass & 40 & 20 & 20 & 5 & 15 & 20 & 73 & 3.65 & 13 \\
\hline Feed formulation & 80 & 6.67 & 0 & 6.67 & 6.67 & 15 & 67 & 4.47 & 14 \\
\hline Desmodium & 26.67 & 20 & 26.67 & 13.33 & 13.33 & 15 & 49 & 3.27 & 15 \\
\hline
\end{tabular}

NB: Only feeds/feed practices mentioned by over 15 respondents are reported in the Table. Total score is the sum of scores for each preference. Scores were got by multiplying frequencies on each preference level by scores assigned where least preference was given a score of 1 and high preference a score of 5 . The overall rank is derived from the total score with the highest having rank 1 . 
Table 33: Reasons why farmers prefer different types of grasses as feeds

\begin{tabular}{|c|c|c|c|c|c|}
\hline Reasons & $\begin{array}{l}\text { Napier } \\
(\mathrm{n}=163)\end{array}$ & $\begin{array}{l}\text { Boma } \\
\text { Rhodes } \\
(n=93)\end{array}$ & $\begin{array}{l}\text { Sudan } \\
\text { grass } \\
(\mathrm{n}=7)\end{array}$ & $\begin{array}{l}\text { Columbus } \\
\text { grass } \\
(\mathrm{n}=17)\end{array}$ & $\begin{array}{l}\text { Nandi setaria } \\
(\mathrm{n}=11)\end{array}$ \\
\hline & \multicolumn{5}{|c|}{ Percentage of farmers } \\
\hline Drought resistant & 14.3 & 2.2 & 0.0 & 0.0 & 0.0 \\
\hline High nutrition content & 13.7 & 7.5 & 0.0 & 17.6 & 18.2 \\
\hline Increase milk production & 12.4 & 25.8 & 14.3 & 23.5 & 27.3 \\
\hline Fast growth & 10.6 & 15.1 & 14.3 & 5.9 & 18.2 \\
\hline Easy to manage & 10.6 & 3.2 & 14.3 & 0.0 & 0.0 \\
\hline High biomass & 9.9 & 7.5 & 0.0 & 5.9 & 0.0 \\
\hline Ability to re-grow after harvest & 6.2 & 5.4 & 0.0 & 0.0 & 0.0 \\
\hline Easy to establish & 5.6 & 2.2 & 0.0 & 0.0 & 0.0 \\
\hline Reliable & 3.1 & 0.0 & 14.3 & 0.0 & 0.0 \\
\hline High palatability & 2.5 & 2.2 & 0.0 & 0.0 & 0.0 \\
\hline $\begin{array}{l}\text { Improve fertility and health of } \\
\text { animal }\end{array}$ & 2.5 & 2.2 & 0.0 & 0.0 & 0.0 \\
\hline Good for silage-making & 2.5 & 0.0 & 0.0 & 5.9 & 0.0 \\
\hline Feed supplement & 2.5 & 0.0 & 0.0 & 0.0 & 9.1 \\
\hline Evergreen & 1.9 & 0.0 & 0.0 & 0.0 & 0.0 \\
\hline To use during drought or deficit & 1.2 & 4.3 & 0.0 & 0.0 & 0.0 \\
\hline $\begin{array}{l}\text { Planting material easily } \\
\text { available }\end{array}$ & 1.2 & 1.1 & 0.0 & 0.0 & 0.0 \\
\hline Longer storage duration & 0.6 & 4.3 & 14.3 & 0.0 & 0.0 \\
\hline Multiple harvests in a year & 0.0 & 1.1 & 0.0 & 0.0 & 0.0 \\
\hline Protein supplement & 0.0 & 0.0 & 14.3 & 41.2 & 0.0 \\
\hline Good for hay making & 0.0 & 8.6 & 14.3 & 0.0 & 27.3 \\
\hline Improve milk production & 0.0 & 2.2 & 0.0 & 0.0 & 0.0 \\
\hline Easy to conserve & 0.0 & 5.4 & 0.0 & 0.0 & 0.0 \\
\hline
\end{tabular}

$\mathrm{n}=$ number of respondents who gave reason for the particular feed/practice 
Lucerne, which was the most preferred herbaceous fodder legume (Table 32), was liked because of its drought resistant ability, use as a protein supplement and the fact that it has the ability to increase milk production (Table 34 ). Two farmers preferred purple vetch because of its ability to increase milk production and one said he preferred it due to the fact that it can be intercropped. Desmodium was preferred mostly because of its use as a protein supplement and its ability to increase milk production. Only one farmer preferred lablab because of its ability to regrow after harvest. Oats was preferred mostly because of its ability to increase milk production while forage sorghum was preferred because of its high nutrition content and the fact that it is dual purpose - used both for human and livestock consumption.

Table 34: Reasons why farmers prefer different types of herbaceous fodder legumes, oats and forage sorghum

\begin{tabular}{|c|c|c|c|c|}
\hline Reasons & $\begin{array}{l}\text { Lucerne } \\
(\mathrm{n}=53)\end{array}$ & $\begin{array}{l}\text { Desmodium } \\
(\mathrm{n}=14)\end{array}$ & Oats $(n=63)$ & $\begin{array}{l}\text { Forage sorghum } \\
(\mathrm{n}=30)\end{array}$ \\
\hline & \multicolumn{4}{|c|}{ Percentage of farmers } \\
\hline Drought resistant & 26.4 & 14.3 & 1.6 & 3.3 \\
\hline Protein supplement & 26.4 & 28.6 & 15.9 & 10.0 \\
\hline $\begin{array}{ll}\text { Increase } & \text { milk } \\
\text { production } & \\
\end{array}$ & 24.5 & 28.5 & 30.2 & 13.3 \\
\hline High nutrition content & 9.4 & 7.1 & 6.3 & 20.0 \\
\hline $\begin{array}{ll}\text { Longer } & \text { storage } \\
\text { duration } & \end{array}$ & 3.8 & 0.0 & 7.9 & 0.0 \\
\hline Fast growth & 3.8 & 0.0 & 15.9 & 3.3 \\
\hline Easy to manage & 3.8 & 0.0 & 12.7 & 6.7 \\
\hline Can be intercropped & 1.9 & 14.3 & 0 & 0.0 \\
\hline $\begin{array}{l}\text { Ability to re-grow } \\
\text { after harvest }\end{array}$ & 0.0 & 0.0 & 0 & 0.0 \\
\hline High palatability & 0.0 & 7.1 & 0 & 0.0 \\
\hline Easy to establish & 0.0 & 0.0 & 0 & 3.3 \\
\hline To use during drought & 0.0 & 0.0 & 11.1 & 0.0 \\
\hline Good for hay-making & 0.0 & 0.0 & 6.3 & 0.0 \\
\hline Easy to conserve & 0.0 & 0.0 & 3.2 & 0.0 \\
\hline High energy & 0.0 & 0.0 & 1.6 & 0.0 \\
\hline Dual purpose & 0.0 & 0.0 & 0.0 & 20.0 \\
\hline $\begin{array}{l}\text { Improve fertility and } \\
\text { health of animal }\end{array}$ & 0.0 & 0.0 & 1.6 & 0.0 \\
\hline Feed supplement & 0.0 & 0.0 & 1.6 & 1.7 \\
\hline
\end{tabular}


Table 35: Reasons why farmers prefer fodder shrubs

\begin{tabular}{|l|r|r|r|r|r|}
\hline & $\begin{array}{l}\text { All fodder } \\
\text { shrubs } \\
(\mathrm{n}=52)\end{array}$ & $\begin{array}{l}\text { Leuceana } \\
(\mathrm{n}=9)\end{array}$ & $\begin{array}{l}\text { Mulberry } \\
(\mathrm{n}=8)\end{array}$ & $\begin{array}{l}\text { Calliandra } \\
(\mathrm{n}=26)\end{array}$ & $\begin{array}{l}\text { Sesbania } \\
\mathrm{n}=7\end{array}$ \\
\hline & \multicolumn{6}{|c|}{ Percentage of farmers } \\
\hline Protein supplement & 34.6 & 22.2 & 37.5 & 38.5 & 14.3 \\
\hline Increase milk production & 21.1 & 11.1 & 25 & 27.0 & 3.9 \\
\hline Easy to manage & 13.5 & 33.3 & 25 & 14.3 \\
\hline High nutrition content & 11.5 & 22.2 & 0 & 11.5 & 14.3 \\
\hline Drought resistant & 3.8 & 0.0 & 0 & 7.7 & 0.0 \\
\hline High palatability & 3.8 & 11.1 & 0 & 3.9 & 0.0 \\
\hline Dual purpose & 3.8 & 0.0 & 0 & 3.9 & 14.3 \\
\hline Fast growth & 1.9 & 0.0 & 0 & 0.0 & 14.3 \\
\hline Easy to establish & 1.9 & 0.0 & 12.5 & 0.0 & 0.0 \\
\hline Bulky & 1.9 & 0.0 & 0.0 & 3.9 & 0.0 \\
\hline Good for hedges & 1.9 & 0.0 & 0.0 & & 14.3 \\
\hline
\end{tabular}

$\mathrm{n}=$ number of respondents who gave reason for the particular feed/practice

Farmers preferred fodder shrubs because of their high nutrition content, and the fact that the shrubs are easy to manage (Table 35). More specifically, leuceana was preferred mostly because it is easy to manage, has high nutrient content and because it is used as a protein supplement; while mulberry was preferred because it is easy to establish and also due to the fact that it is used as a protein supplement. Calliandra was preferred because of its protein content, increases milk production and the fact that it has high nutrient content. Only two farmers indicated their preference for tree lucerne and its ability to be used as a protein supplement.

Crop residues were preferred because they have high nutrition content, are used during the dry season and some of them can be stored for long (Table 36). More specifically, green maize stalk was preferred because of its high nutrient content while dry maize stover was preferred because it can be stored for a long duration of time for use during dry periods. Hay and silage were preferred mostly because they can be used during the dry season when there's a deficit of feeds while commercially mixed concentrates and feed formulations were preferred mostly because of their ability to increase milk production (Table 37). 
Table 36: Reasons why farmers prefer crop residues

\begin{tabular}{|l|c|c|c}
\hline & \multicolumn{1}{|l|}{$\begin{array}{l}\text { Wheat straw } \\
(\mathrm{n}=9)\end{array}$} & $\begin{array}{l}\text { Maize stalk (green) } \\
\mathrm{n}=48\end{array}$ & Maize-stover (dry) $\mathrm{n}=103$ \\
\hline & \multicolumn{3}{|c}{ Percentage of farmers } \\
\hline High nutrition content & 22.2 & 47.92 & 8.74 \\
\hline Used during drought or deficit & 22.2 & 12.50 & 20.39 \\
\hline Reliable & 22.2 & 8.33 & 9.71 \\
\hline Longer storage duration & 11.1 & 0 & 22.33 \\
\hline Increase milk production & 11.1 & 8.33 & 8.74 \\
\hline Easy to conserve & 11.1 & 4.17 & 2.91 \\
\hline Protein supplement & 0.0 & 2.08 & 0.97 \\
\hline High palatability & 0.0 & 6.25 & 0.97 \\
\hline Easy to establish & 0.0 & 0.0 & 0.97 \\
\hline Easy to manage & 0.0 & 4.17 & 3.68 \\
\hline Bulky & 0.0 & 0.0 & 0.97 \\
\hline Evergreen & 0.0 & 2.08 & 0.97 \\
\hline Dual purpose & 0.0 & 0.0 & 0.97 \\
\hline Improve fertility and health of & & & 1.94 \\
animal & 0.0 & 0.0 & 4.85 \\
\hline Good for silage-making & 0.0 & 2.08 & 2.08 \\
\hline Feed supplement & 0.0 & &
\end{tabular}

$\mathrm{n}=$ number of respondents who gave reason for the particular feed/practice 
Table 37: Reasons why farmers prefer different types of feed practices

\begin{tabular}{|c|c|c|c|c|c|c|}
\hline & $\begin{array}{l}\text { Mineral } \\
\text { supplementation } \\
(\mathrm{n}=31)\end{array}$ & $\begin{array}{l}\text { Ration } \\
\text { formulation } \\
(\mathrm{n}=13)\end{array}$ & Hay $(n=40)$ & $\begin{array}{l}\text { Silage } \\
(\mathrm{n}=31)\end{array}$ & $\begin{array}{l}\text { Pasture } \\
\text { improvement }(n=8)\end{array}$ & $\begin{array}{l}\text { Commercially mixed } \\
\text { concentrates }(\mathrm{n}=63)\end{array}$ \\
\hline & \multicolumn{6}{|c|}{ Percentage of farmers } \\
\hline To use during drought or deficit & 29.0 & 23.1 & 37.5 & 25.8 & 0 & 12.7 \\
\hline High nutrition content & 16.1 & 15.4 & 5 & 16.1 & 25 & 6.4 \\
\hline Longer storage duration & 16.1 & 0.0 & 15 & 3.2 & 0 & 7.9 \\
\hline Increase milk production & 9.7 & 38.5 & 12.5 & 16.1 & 25 & 30.2 \\
\hline Reliable & 9.7 & 0.0 & 2.5 & 3.2 & 0 & \\
\hline Easy to manage & 6.5 & 15.4 & 5 & 0.0 & 0 & 12.7 \\
\hline Easy to store for long & 6.5 & 0.0 & 10 & 9.7 & 0 & 3.2 \\
\hline Protein supplement & 3.2 & 0.0 & 0 & 9.7 & 12.5 & 0.0 \\
\hline Feed supplement & 3.2 & 0.0 & 0 & 0.0 & 0 & 1.6 \\
\hline High palatability & 0.0 & 0.0 & 0 & 3.2 & 0 & \\
\hline Planting material easily available & 0.0 & 0.0 & 0 & 0.0 & 12.5 & \\
\hline Provides high energy & 0.0 & 0.0 & 2.5 & 0.0 & 0 & \\
\hline Improve animal productivity & 0.0 & 7.7 & 0 & 0.0 & 25 & 1.6 \\
\hline Improve fertility and health of animal & 0.0 & 0.0 & 0 & 0.0 & 0 & 1.6 \\
\hline
\end{tabular}

$\mathrm{n}=$ number of respondents who gave reasons for the particular feed/practice

NB: Some respondents gave invalid reasons hence the total does not in some cases add up to 100 


\section{Reasons why farmers do not prefer certain feeds/feed practices}

Table 38: Reasons why farmers do not prefer certain grasses

\begin{tabular}{|c|c|c|c|c|c|}
\hline & $\begin{array}{l}\text { Napier } \\
\text { grass } \\
(n=100)\end{array}$ & $\begin{array}{l}\text { Boma } \\
\text { Rhodes } \\
(n=4)\end{array}$ & $\begin{array}{l}\text { Sudan } \\
(\mathrm{n}=7)\end{array}$ & $\begin{array}{l}\text { Nandi setaria } \\
(\mathrm{n}=6)\end{array}$ & $\begin{array}{l}\text { Columbus } \\
\text { grass }(n=14)\end{array}$ \\
\hline Reason & \multicolumn{5}{|c|}{ Percentage of farmers } \\
\hline Not drought resistant & 44.0 & 36.4 & 14.3 & 33.3 & 14.3 \\
\hline Requires fertile soils & 14.0 & 0.0 & 0.0 & 0.0 & 0.0 \\
\hline Skin and throat irritation & 9.0 & 11.4 & 0.0 & 0.0 & 28.6 \\
\hline Grows slowly & 8.0 & 6.8 & 14.3 & 0.0 & 0.0 \\
\hline Bulky & 7.0 & 4.5 & 0.0 & 16.7 & 7.1 \\
\hline Causes bloat & 6.0 & 13.6 & 0.0 & 16.7 & 14.3 \\
\hline $\begin{array}{l}\text { Less milk production when } \\
\text { fed few hours to milking }\end{array}$ & 5.0 & 2.3 & 0.0 & 0.0 & 0.0 \\
\hline Low yields & 3.0 & 6.8 & 14.3 & 0.0 & 14.3 \\
\hline $\begin{array}{l}\text { Unavailability } \\
\text { seeds/planting material }\end{array}$ & 1.0 & 0.0 & 0.0 & 16.7 & 0.0 \\
\hline High mortality rate & 1.0 & 4.5 & 0.0 & 0.0 & 0.0 \\
\hline Not fed fresh & 1.0 & 2.3 & 0.0 & 0.0 & 7.1 \\
\hline Not very palatable & 1.0 & 0.0 & 0.0 & 0.0 & 0.0 \\
\hline Seeds expensive & 0.0 & 4.5 & 14.3 & 0.0 & 0.0 \\
\hline $\begin{array}{l}\text { Difficult to establish after } \\
\text { transplant }\end{array}$ & 0.0 & 0.0 & 14.3 & 0.0 & 0.0 \\
\hline $\begin{array}{l}\text { Taints milk if fed few hours to } \\
\text { milking }\end{array}$ & 0.0 & 0.0 & 14.3 & 0.0 & 0.0 \\
\hline Not perennial & 0.0 & 0.0 & 0.0 & 0.0 & 7.1 \\
\hline Requires storage facilities & 0.0 & 2.3 & 0.0 & 0.0 & 0.0 \\
\hline Expensive & 0.0 & 2.3 & 0.0 & 16.7 & 0.0 \\
\hline Seasonal & 0.0 & 0.0 & 0.0 & 0.0 & 7.1 \\
\hline
\end{tabular}

$\mathrm{n}=$ total number of farmers that responded to the question

When asked about reasons why they did not prefer certain grasses, not being drought resistance was mentioned by a substantial number of farmers (Table 38). Other reasons included skin and throat irritation for Napier grass, bloat, slow growth, etc. Reasons for herbaceous fodder legumes varied from high mortality rate for lupin, low biomass for desmodium, high cost of seed for lucerne and unavailability of seeds for lupin, lucerne and desmodium (Table 39). One farmer cited difficulty in establishment after transplanting for lablab. A substantial number of farmers also mentioned bloat as a reason 
why they did not prefer lucerne. Lucerne was also said to taint milk if fed to livestock a few hours to milking.

Table 39: Reasons why farmers do not prefer certain herbaceous fodder legumes

\begin{tabular}{|c|c|c|c|}
\hline & Lupin $(n=9)$ & Lucerne $(n=21)$ & $\begin{array}{l}\text { Desmodium } \\
(\mathrm{n}=10)\end{array}$ \\
\hline & \multicolumn{3}{|c|}{ \# of farmers } \\
\hline High mortality rate & 4 & 0 & 0 \\
\hline Unavailability of seeds & 2 & 3 & 2 \\
\hline Labour intensive & 2 & 1 & 1 \\
\hline Skin and throat irritation & 1 & 0 & 0 \\
\hline Seeds expensive & 0 & 6 & 2 \\
\hline $\begin{array}{l}\text { Difficult to establish after } \\
\text { transplant }\end{array}$ & 0 & 0 & 0 \\
\hline $\begin{array}{l}\text { Taints milk if fed few hours } \\
\text { to milking }\end{array}$ & 0 & 1 & 0 \\
\hline Not drought resistant & 0 & 1 & 0 \\
\hline Difficult to establish & 0 & 1 & 0 \\
\hline Not fed fresh & 0 & 1 & 0 \\
\hline Requires fertile soils & 0 & 1 & 1 \\
\hline Grows slowly & 0 & 2 & 0 \\
\hline Expensive & 0 & 1 & 0 \\
\hline Low biomass & 0 & 0 & 4 \\
\hline Causes bloat & 0 & 3 & 0 \\
\hline
\end{tabular}

$\mathrm{n}=$ total number of households that responded to the question

Reasons given for fodder shrubs were unavailability of seeds and if available they were expensive (Table 40). Forage sorghum and oats were not preferred by some farmers because they considered them labour intensive (Table 41). 
Table 40: Reasons why farmers do not prefer certain fodder shrubs

\begin{tabular}{|c|c|c|c|c|c|}
\hline Reasons & $\begin{array}{l}\text { All } \\
n=25\end{array}$ & $\begin{array}{l}\text { Sesbania } \\
n=5\end{array}$ & $\begin{array}{l}\text { Leuceana } \\
n=4\end{array}$ & $\begin{array}{l}\text { Mulberry } \\
n=2\end{array}$ & $\begin{array}{l}\text { Calliandra } \\
n=14\end{array}$ \\
\hline & \multicolumn{5}{|c|}{ \# of farmers } \\
\hline Unavailability of seeds & 6 & 0 & 1 & 0 & 5 \\
\hline Seeds expensive & 2 & 0 & 1 & 0 & 1 \\
\hline $\begin{array}{l}\text { Lack of knowledge on } \\
\text { management }\end{array}$ & 1 & 1 & 0 & 0 & 0 \\
\hline Labour intensive & 4 & 1 & 0 & 0 & 3 \\
\hline Not drought resistant & 3 & 1 & 1 & 0 & 1 \\
\hline Requires fertile soils & 1 & 0 & 0 & 1 & \\
\hline Grows slowly & 8 & 2 & 1 & 1 & 4 \\
\hline
\end{tabular}

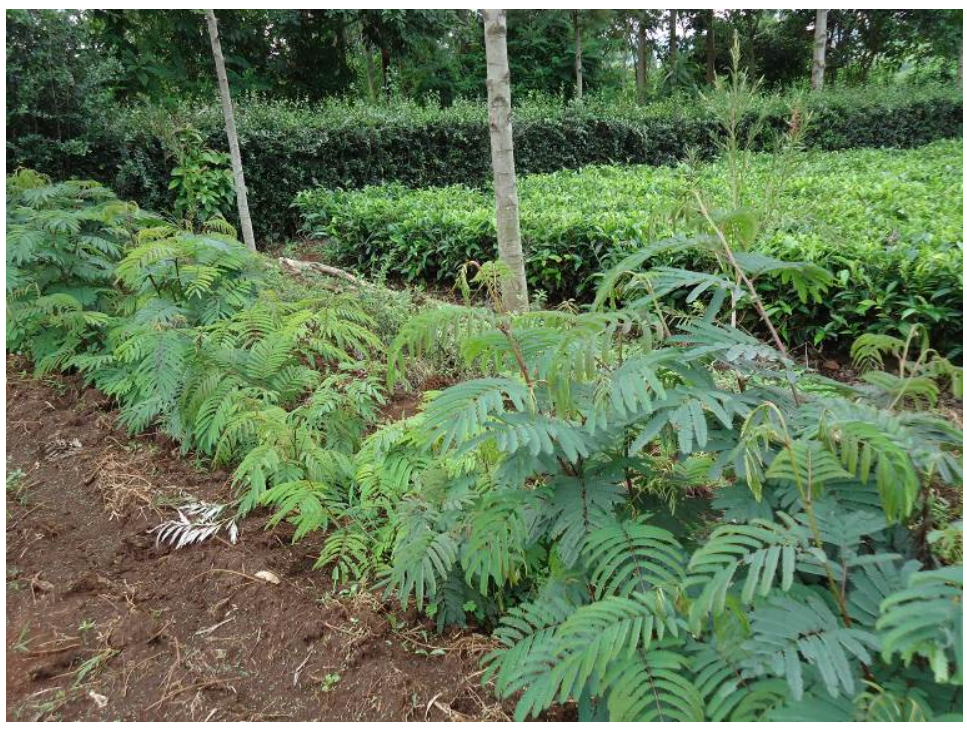

Calliandra hedge 
Table 41: Reasons why some farmers do not prefer oats and forage sorghum

\begin{tabular}{|c|c|c|}
\hline Reason & Oats $(n=28)$ & $\begin{array}{ll}\text { Forage } & \text { sorghum } \\
(n=17) & \end{array}$ \\
\hline & \multicolumn{2}{|c|}{ \# of farmers } \\
\hline Labour intensive & 6 & 6 \\
\hline Requires more storage & 5 & 0 \\
\hline Seeds expensive & 4 & 3 \\
\hline Poor germination during high rainfall & 3 & 0 \\
\hline Not drought resistant & 3 & 0 \\
\hline Expensive & 2 & 0 \\
\hline Unavailability of seeds & 1 & 0 \\
\hline Lacks nutrients & 1 & 0 \\
\hline Grows slowly & 1 & 5 \\
\hline Requires more acreage & 1 & 0 \\
\hline Seasonal & 1 & 0 \\
\hline Lack of knowledge on management & 0 & 1 \\
\hline Difficult to establish & 0 & 1 \\
\hline Needs supplementation & 0 & 1 \\
\hline
\end{tabular}

$\mathrm{n}=$ total number of households that responded to the question 
Table 42: Reasons why some farmers do not prefer feed formulation, hay and silage

\begin{tabular}{|l|r|r|r|}
\hline & $\begin{array}{l}\text { Feed } \\
\text { formulation } \\
(\mathrm{n}=11)\end{array}$ & $\begin{array}{l}\text { Hay baling } \\
(\mathrm{n}=14)\end{array}$ & $\begin{array}{l}\text { Silage making } \\
(\mathrm{n}=14)\end{array}$ \\
\hline & 5 & 4 & \multicolumn{3}{|c|}{ \# of farmers } \\
\hline Labour intensive & 1 & 0 & 0 \\
\hline Needs supplementation & 2 & 0 & 0 \\
\hline Unavailability of seeds & 2 & 0 & 0 \\
\hline Lacks nutrients & 1 & 0 & 3 \\
\hline Feeds seasonal & 0 & 2 & 0 \\
\hline Lack of knowledge & 0 & 1 & 10 \\
\hline $\begin{array}{l}\text { Materials for making hay grow } \\
\text { slowly }\end{array}$ & 0 & 0 & 0 \\
\hline $\begin{array}{l}\text { Less milk production when fed a } \\
\text { few hours to milking }\end{array}$ & 0 & 3 & 0 \\
\hline Bulky & 0 & 4 & 0 \\
\hline Requires more storage & & 0 & 0 \\
\hline
\end{tabular}

$\mathrm{n}=$ total number of farmers that responded to the question

Slightly more than 70 percent of the farmers who did not prefer silage-making said they considered it labour intensive. Slightly less than 40 percent and 30 percent of farmers did not prefer feed formulation and hay baling respectively because they considered the two practices to be labour intensive (Table 42). Hay was also not preferred by some farmers because it requires storage facilities. One farmer indicated that he does not prefer dairy meal because it taints milk if fed few hours to milking. 


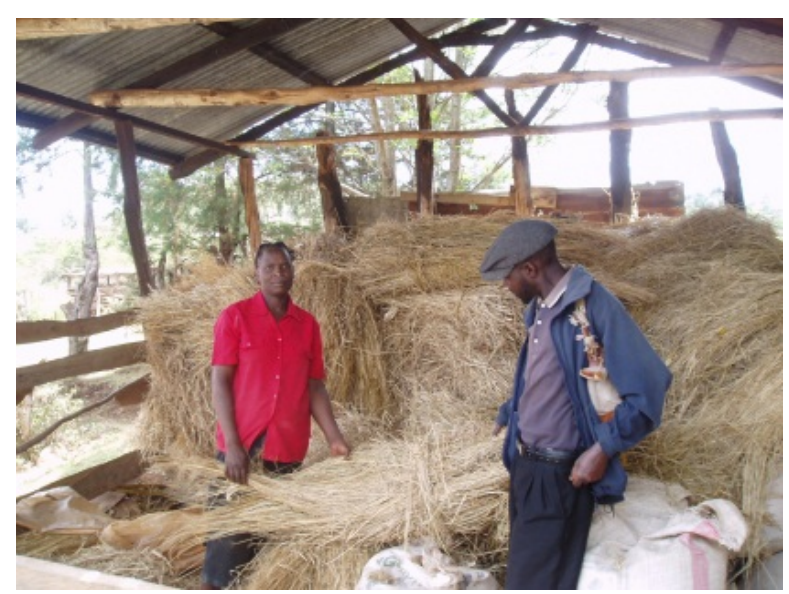

Hay in a store in Rift Valley, Kenya

\subsection{Feeds and feed practices that farmers have not taken up and reasons}

Table 43: Reasons why some farmers have not adopted certain grasses

\begin{tabular}{|c|c|c|c|c|c|}
\hline & $\begin{array}{l}\text { Napier } \\
\text { grass } \\
(\mathrm{n}=6)\end{array}$ & $\begin{array}{l}\text { Boma } \\
\text { Rhodes ( } \\
n=43)\end{array}$ & $\begin{array}{l}\text { Columbus } \\
\text { grass } \\
(\mathrm{n}=18) \\
\end{array}$ & $\begin{array}{l}\text { Nandi } \\
\text { setaria }(n=24 \\
\end{array}$ & $\begin{array}{l}\text { Sudan } \\
\text { grass }(n=6)\end{array}$ \\
\hline & \multicolumn{5}{|c|}{ Percentage of farmers } \\
\hline Inadequate land & 50.0 & 23.3 & 11.1 & 29.2 & 0.0 \\
\hline $\begin{array}{l}\text { Unavailability of planting } \\
\text { material/seed }\end{array}$ & 16.7 & 27.9 & 44.4 & 58.3 & 50.0 \\
\hline Lack of technical knowledge & 16.7 & 9.3 & 22.2 & 8.3 & 0.0 \\
\hline Labour intensive & 16.7 & 0.0 & 5.6 & 0 & 0.0 \\
\hline Poor performance on the farm & 0.0 & 7.0 & 16.7 & 0.0 & 16.7 \\
\hline Affected by weather & 0.0 & 0.0 & 0.0 & 0.0 & 16.7 \\
\hline Requires a lot of capital & 0.0 & 2.3 & 0.0 & 0.0 & 0.0 \\
\hline Good return from cash crops & 0.0 & 2.3 & 0.0 & 0.0 & 0.0 \\
\hline Just learnt about it & 0.0 & 2.3 & 0.0 & 0.0 & 0.0 \\
\hline Slow growth & 0.0 & 2.3 & 0.0 & 0.0 & 0.0 \\
\hline Expensive seeds & 0.0 & 23.3 & 0.0 & 4.2 & 16.7 \\
\hline
\end{tabular}

$\mathrm{n}=$ total number of farmers that responded to the question 
Out of the total sample of 181 farmers, only six farmers $(3.3 \%)$ had not taken up Napier grass. Half of the farmers cited inadequate land while the others cited unavailability of planting material, lack of technical knowledge and it'slabour intensive. Of the 23.7 percent of the total sample who had not taken up Boma Rhodes, 27.9 percent indicated unavailability of seeds and inadequate land (23.3\%) as some of the reasons (Table 43). The main impediment for uptake of Columbus grass and Nandi setaria was lack of seeds, technical knowledge and inadequate land. Lack of seeds was mentioned as the main reason for lack of adoption of herbaceous fodder legumes. Apart from the lack of seeds, high cost was also an impediment (Table 44), Two farmers indicated having inadequate technical knowledge for lupin while one indicated lack of seeds. Unavailability of planting material/seeds was mentioned by farmers as the main reason for non-adoption of fodder shrubs such as calliandra (Table 45). Out of six farmers who gave reasons for nonadoption of sesbania, half of them cited unavailability of planting material. Two farmers who had not taken up mulberry cited unavailability of planting material as a reason. Half of the farmers who had not adopted forage sorghum and oats cited unavailability of planting material as the main reason for non-adoption (Table 44).

Table 44: Reasons why some farmers have not adopted herbaceous legumes

\begin{tabular}{|c|c|c|}
\hline & $\begin{array}{l}\text { Lucerne } \\
(\mathrm{n}=100)\end{array}$ & Desmodium (n=56) \\
\hline & \multicolumn{2}{|c|}{ Percentage of farmers } \\
\hline Lack of seeds & 41.0 & 55.4 \\
\hline Expensive seeds & 22.0 & 16.1 \\
\hline Lack of technical knowledge & 19.0 & 16.1 \\
\hline Inadequate land & 10.0 & 3.6 \\
\hline Poor performance on the farm & 3.0 & 1.8 \\
\hline Affected by weather & 2.0 & 1.8 \\
\hline Difficult to establish & 1.0 & 0.0 \\
\hline Low yields & 1.0 & 0.0 \\
\hline Labour intensive & 1.0 & 1.8 \\
\hline Requires a lot of capital & 0.0 & 3.6 \\
\hline
\end{tabular}


Table 45: Reasons why some farmers have not adopted fodder shrubs

\begin{tabular}{|l|r|r|}
\hline & Calliandra $(\mathrm{n}=32)$ & \multicolumn{2}{|c|}{ Sesbania $(\mathrm{n}=6)$} \\
\hline & \multicolumn{2}{|c|}{ Percentage of farmers } \\
\hline $\begin{array}{l}\text { Unavailability of } \\
\text { planting material }\end{array}$ & 0.0 & 50.0 \\
\hline Affected by weather & 3.1 & 0.0 \\
\hline Difficult to establish & 0.0 & 0.0 \\
\hline Short life span & 3.1 & 16.7 \\
\hline $\begin{array}{l}\text { Lack of technical } \\
\text { knowledge }\end{array}$ & 6.3 & 16.7 \\
\hline Expensive seeds & 0.0 & 0.0 \\
\hline Labour intensive & & 16.7 \\
\hline
\end{tabular}

$\mathrm{n}=$ total number of farmers that responded to the question

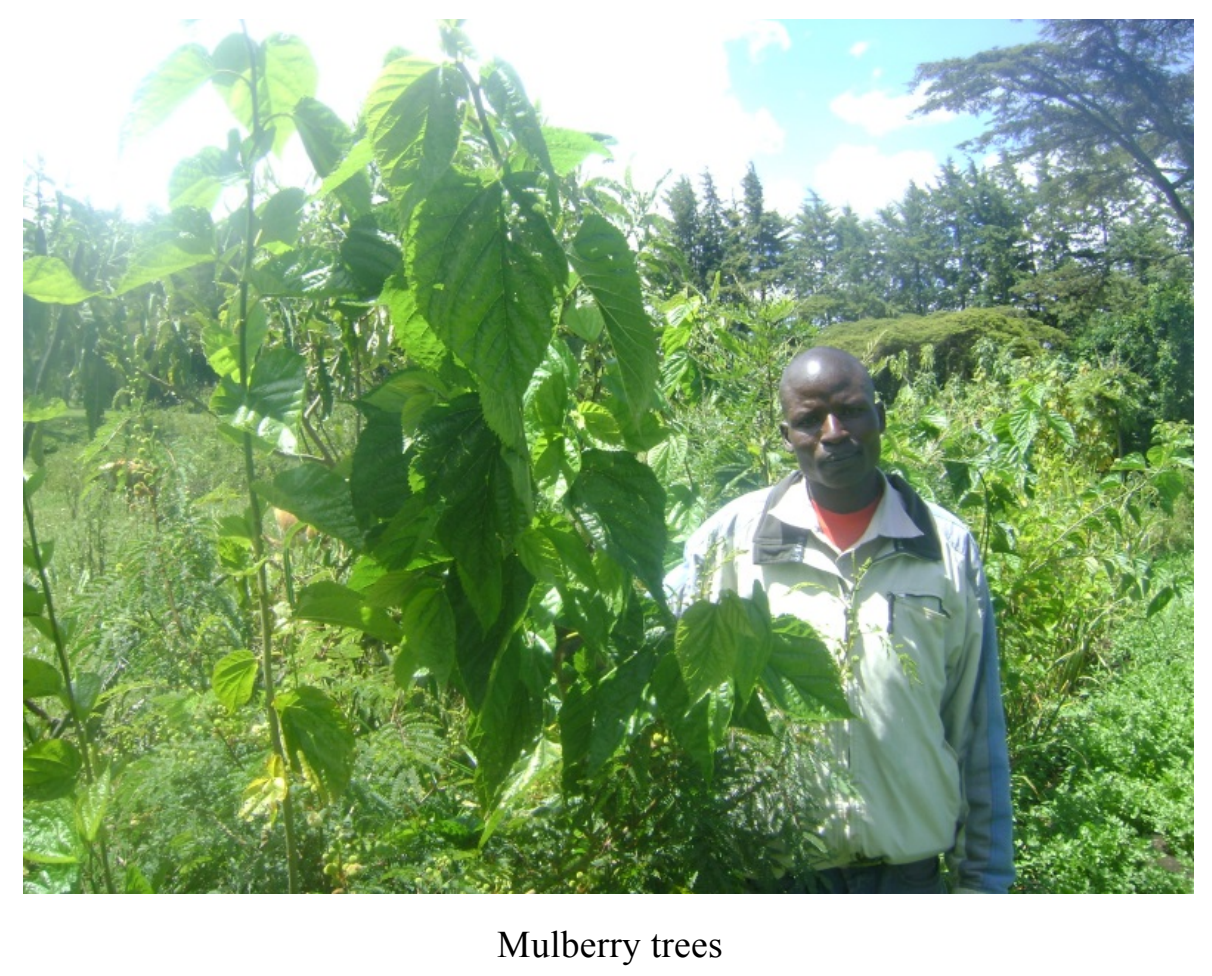


Table 46: Reasons why some farmers have not adopted oats, forage sorghum and sweet potato vines

\begin{tabular}{|l|r|r|r|}
\hline & & \multicolumn{1}{|l|}{$\begin{array}{l}\text { Forage } \\
\text { sorghum } \\
(\mathrm{n}=30)\end{array}$} & $\begin{array}{l}\text { Sweet } \\
\text { potato vines } \\
(\mathrm{n}=6)\end{array}$ \\
\hline & Oats $(\mathrm{n}=31)$ & \multicolumn{2}{|c|}{ Percentage of farmers } \\
\hline Lack of seeds & 51.6 & 50.0 & 0.0 \\
\hline Inadequate land & 25.8 & 23.3 & 25.0 \\
\hline Lack of technical knowledge & 9.7 & 6.7 & 6.3 \\
\hline Unavailability of planting material & 3.2 & 3.3 & 25.0 \\
\hline Requires a lot of capital & 3.2 & 0.0 & 0.0 \\
\hline Difficult to establish & 3.2 & 0.0 & 16.7 \\
\hline Labour intensive & 3.2 & 3.3 & 0.0 \\
\hline Limited time & 0.0 & 3.3 & 6.3 \\
\hline Poor performance on the farm & 0.0 & 3.3 & 6.3 \\
\hline Affected by weather & 0.0 & 0.0 & 0.0 \\
\hline Low yields & 0.0 & 3.3 & 3.3 \\
\hline Slow growth & 0.0 & & \\
\hline
\end{tabular}

$\mathrm{n}=$ total number of households that responded to the question 
Table 47: Reasons why some farmers have not adopted various feed practices and crop residues

\begin{tabular}{|c|c|c|c|c|}
\hline & $\begin{array}{l}\text { Sunflower } \\
\text { cake }(n=34)\end{array}$ & $\begin{array}{l}\text { Silage } \\
\text { making } \\
(n=63)\end{array}$ & $\begin{array}{l}\text { Hay } \\
\text { making } \\
(n=30)\end{array}$ & $\begin{array}{l}\text { Feed } \\
\text { formulation } \\
(\mathrm{n}=13)\end{array}$ \\
\hline & \multicolumn{4}{|c|}{ Percentage of farmers } \\
\hline Unavailability of planting material & 38.2 & 0.0 & 0.0 & 0.0 \\
\hline Inadequate land & 23.5 & 1.6 & 6.7 & 0.0 \\
\hline Lack of technical knowledge & 14.7 & 23.8 & 23.3 & 15.4 \\
\hline Requires a lot of capital & 5.9 & 19.0 & 23.3 & 0.0 \\
\hline Poor performance on the farm & 5.9 & 0.0 & 0.0 & 0.0 \\
\hline Labour intensive & 2.9 & 11.1 & 20.0 & 0.0 \\
\hline Affected by wild animals & 2.9 & 1.6 & 0.0 & 0.0 \\
\hline Low yields & 2.9 & 0.0 & 0.0 & 0.0 \\
\hline Just learnt about it & 2.9 & 0.0 & 0.0 & 0.0 \\
\hline Lack of ingredients & 0.0 & 39.7 & 23.3 & 0.0 \\
\hline Limited time & 0.0 & 1.6 & 0.0 & 84.6 \\
\hline Affected by weather & 0.0 & 1.6 & 0.0 & 0.0 \\
\hline Expensive seeds & 0.0 & 0.0 & 0.0 & 0.0 \\
\hline Difficult to establish & 0.0 & 0.0 & 3.3 & 0.0 \\
\hline
\end{tabular}

$\mathrm{n}=$ total number of households that responded to the question

Lack of ingredients was mentioned by about 40 percent of farmers who had not adopted silage-making as the main reason (Table 47). For those farmers who had not taken up the use of sunflower cake, 38.2 percent cited unavailability of planting material as the main reason.

\subsection{Constraints and interventions in production of feeds and feed practices}

Farmers experience different types of constraints in producing grasses. The main constraint for Napier grass, Boma Rhodes and Columbus grass experienced by farmers was labour (Table 48). The main constraint in producing Nandi setaria was difficulty in establishment followed by labour. 
Table 48: Main constraints in producing grasses

\begin{tabular}{|l|l|l|l|l|}
\hline Constraint & $\begin{array}{l}\text { Napier } \\
(\mathrm{n}=169)\end{array}$ & $\begin{array}{l}\text { Boma } \\
\text { Rhodes } \\
(\mathrm{n}=89)\end{array}$ & $\begin{array}{l}\text { Columbus } \\
\text { grass }(\mathrm{n}=8)\end{array}$ & Nandi setaria $\mathrm{n}=9$ \\
\hline & \multicolumn{4}{|c|}{ Percentage of farmers } \\
\hline Labour intensive & 58.6 & 31.5 & 16.7 & 33.3 \\
\hline Inputs & 9.5 & 12.4 & 11.1 & 0.0 \\
\hline $\begin{array}{l}\text { Establishment/low } \\
\text { germination }\end{array}$ & 8.3 & 29.2 & 5.6 & 44.4 \\
\hline Inadequate land & 6.5 & 2.2 & 5.6 & 0.0 \\
\hline $\begin{array}{l}\text { Pests and diseases } \\
\text { (moles, rats) }\end{array}$ & 3.6 & 0.0 & 0.0 & 0.0 \\
\hline $\begin{array}{l}\text { Seeds/planting material } \\
\text { not available }\end{array}$ & 3.6 & 13.5 & 16.7 & 22.2 \\
\hline Management & 1.2 & 0.0 & 5.6 & 0.0 \\
\hline Overgrazed & 1.2 & 0.0 & 0.0 & 0.0 \\
\hline $\begin{array}{l}\text { Too much } \\
\text { rain/frost/drought }\end{array}$ & 11.9 & 6.8 & 11.1 & 0.0 \\
\hline Needs supplementation & 0.6 & 1.1 & 22.2 & 0.0 \\
\hline Seasonal & 0.6 & 0.0 & 5.6 & 0.0 \\
\hline Storage & 0.0 & 3.4 & 0.0 & 0.0 \\
\hline
\end{tabular}

$\mathrm{n}=$ total number of farmers that responded to the question 
Table 49: Proposed interventions to constraints related to the production of grasses

\begin{tabular}{|c|c|c|}
\hline Grasses & Constraint in production & Proposed intervention \\
\hline \multirow[t]{10}{*}{ Napier grass } & Difficult to establish & Proper timing \\
\hline & Labour intensive & Hire labourers \\
\hline & & Use chaff cutter \\
\hline & Irritating when harvesting & $\begin{array}{l}\text { Harvest early in the morning } \\
\text { Wear protective clothing }\end{array}$ \\
\hline & Weeds & $\begin{array}{l}\text { Regular weeding } \\
\text { Use herbicides }\end{array}$ \\
\hline & Infertile soils & Use manure \\
\hline & Overgrown & $\begin{array}{l}\text { Make silage } \\
\text { Harvest when 3-4ft }\end{array}$ \\
\hline & Pests and diseases (moles, rats) & $\begin{array}{l}\text { Pesticides } \\
\text { Seek advice from MOALFD }\end{array}$ \\
\hline & Inadequate land & $\begin{array}{l}\text { Training on where to plant on } \\
\text { the farm }\end{array}$ \\
\hline & Needs supplementation & $\begin{array}{l}\text { Mix with other feeds/add } \\
\text { molasses }\end{array}$ \\
\hline \multirow[t]{7}{*}{ Boma Rhodes } & Labour intensive & Use chaff cutter/pulverizer \\
\hline & Weeds & Regular weeding, herbicides \\
\hline & $\begin{array}{l}\text { Weather/frost/too much } \\
\text { rain/drought }\end{array}$ & Proper timing \\
\hline & Seeds not available & Avail seeds at Agrovets \\
\hline & Seeds expensive & Avail affordable seeds \\
\hline & Low quality seeds & Use certified seed \\
\hline & Low germination & Use cuttings/root splits \\
\hline Giant setaria & Weeds & Regular weeding \\
\hline \multirow[t]{3}{*}{ Columbus grass } & Weeds & Regular weeding \\
\hline & Drought & Proper timing of rains \\
\hline & Unavailability of seeds & Avail seeds at Agrovets \\
\hline
\end{tabular}

Proposed interventions for tackling the problem of labour in grasses was hiring more labourers and also using a chaff cutter to chop (Table 49). For those who experienced skin and throat irritation when harvesting Napier, farmers said harvesting early in the morning solves the problem. If not, one should wear protective clothing. Boma Rhodes was reported by many farmers to have a problem of low germination. The suggested intervention was for farmers to use root splits instead of seeds. Seeds for Boma Rhodes were not easily available, and if available they were expensive. The proposed solution was to avail affordable seeds at PO agrovets.

The main constraints in producing lucerne were labour and seeds while for desmodium and lucerne it was seed (Table 50). To tackle the problem of seeds, farmer suggested that seeds should be availed at the POs agrovets (Table 51). For oats, the main problem was seeds/planting material, while for sorghum and sweet potato vines it was labour (Table 52). 
Proposed interventions included availing affordable seeds/planting material at the POs agrovets among other interventions (Table 53). The main constraint in production of silage was inputs followed by labour (Table 54). For hay, the main problem was labour (Table 55). Proposed interventions included availing affordable silage bags, using hay boxes for baling among other interventions (Table 56).

Table 50: Main constraints in producing herbaceous legumes and fodder shrubs

\begin{tabular}{|l|l|l|l|}
\hline Constraint in production & $\begin{array}{l}\text { Lucerne } \\
\mathrm{n}=24\end{array}$ & $\begin{array}{l}\text { Desmodium } \\
\mathrm{N}=12\end{array}$ & $\begin{array}{l}\text { Fodder } \\
(\mathrm{n}=23)\end{array}$ \\
\hline & \multicolumn{3}{|c|}{ Percentage of farmers } \\
\hline Labour intensive & 25.0 & 8.3 & 4.3 \\
\hline Seeds unavailable & 25.0 & 58.3 & 60.9 \\
\hline Establishment difficult & 16.7 & 8.3 & 17.4 \\
\hline Inputs expensive & 8.3 & 16.7 & 0.0 \\
\hline Management & 8.3 & 0.0 & 0.0 \\
\hline Pests and diseases & 8.3 & 0.0 & 13.0 \\
\hline Frost & 4.2 & 0.0 & 0.0 \\
\hline Inadequate land & 4.2 & 8.3 & 0.0 \\
\hline Drought & 0.0 & 0.0 & 4.3 \\
\hline
\end{tabular}

Table 51: Proposed interventions to constraints related to the production of lucerne, desmodium, fodder shrubs and oats

\begin{tabular}{|l|l|l|}
\hline Technology & Constraint in production & \multicolumn{2}{l|}{ Proposed intervention } \\
\hline Lucerne & Unavailability of seeds & $\begin{array}{l}\text { Avail seeds/planting material } \\
\text { at agrovets }\end{array}$ \\
\cline { 2 - 3 } & Weeds & Regular weeding \\
\cline { 2 - 3 } & Seeds expensive & $\begin{array}{l}\text { Avail affordable planting } \\
\text { material at agrovets }\end{array}$ \\
\cline { 2 - 3 } & Pests and diseases & $\begin{array}{l}\text { Avaining on control seeds/planting material } \\
\text { at agrovets }\end{array}$ \\
\hline Desmodium & Planting material unavailable & $\begin{array}{l}\text { Avail seeds/planting material } \\
\text { at agrovets }\end{array}$ \\
\hline Fodder shrubs & Seeds not available &
\end{tabular}


Table 52: Constraints experienced in producing oats, sorghum and sweet potato vines

\begin{tabular}{llll}
\hline Problem & Oats $(\mathrm{n}=59)$ & $\begin{array}{l}\text { Sorghum } \\
(\mathrm{n}=24)\end{array}$ & $\begin{array}{l}\text { Sweet potato vines } \\
(\mathrm{n}=23)\end{array}$
\end{tabular}

\begin{tabular}{|l|l|l|l|}
\hline & \multicolumn{3}{|c|}{ Percentage of farmers } \\
\hline $\begin{array}{l}\text { Unavailability of } \\
\text { seeds/planting material }\end{array}$ & 32.2 & 25.0 & 17.4 \\
\hline High cost of inputs & 23.7 & 4.2 & 4.4 \\
\hline Labour intensive & 10.2 & 45.8 & 43.5 \\
\hline Inadequate land & 6.8 & 0.0 & 4.4 \\
\hline Difficult to establish & 5.1 & 8.3 & 13.0 \\
\hline Seasonal & 5.1 & 0.0 & 0.0 \\
\hline Lack of storage & 3.4 & 0.0 & 8.7 \\
\hline $\begin{array}{l}\text { Weather (drought, too } \\
\text { much rain) }\end{array}$ & 13.6 & 4.2 & 0.0 \\
\hline Pests and diseases & 0.0 & 12.5 & 8.7 \\
\hline
\end{tabular}

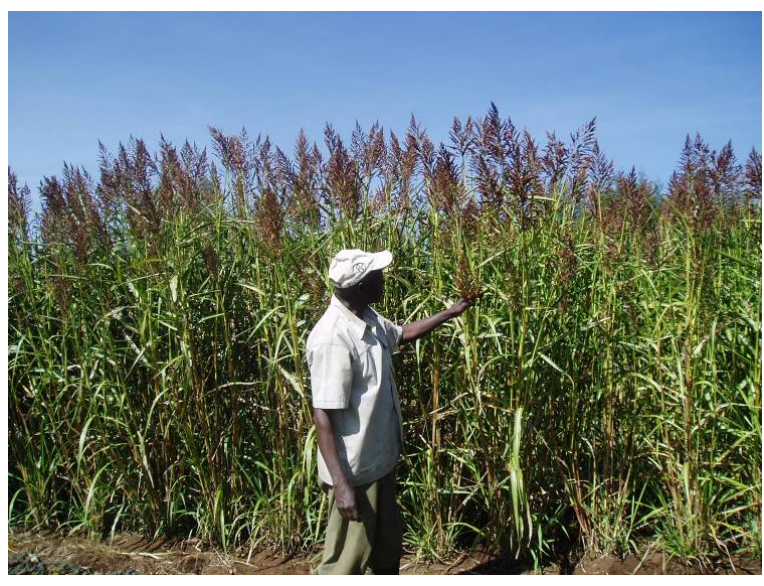

Forage sorghum

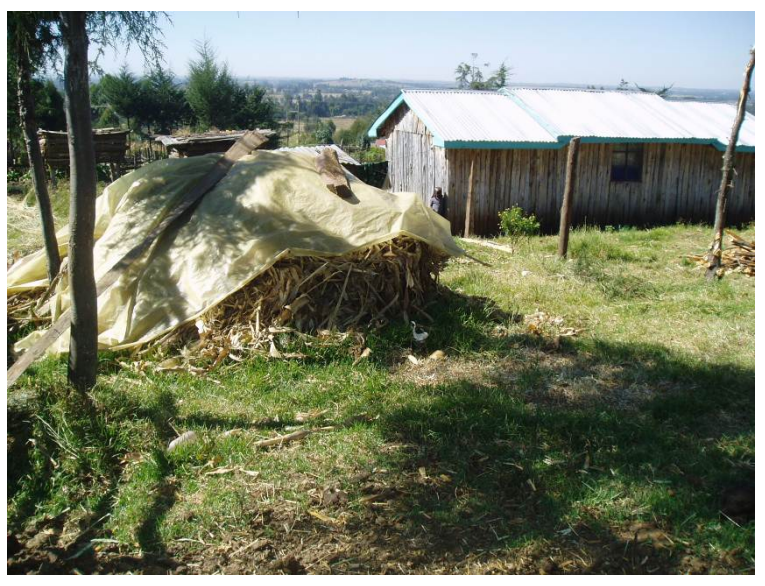

Dry maize stover in central Kenya 
Table 53: Proposed interventions to constraints related to the production of oats, forage sorghum and sweet potato vines

\begin{tabular}{|c|c|c|}
\hline Technology & Constraint & Proposed intervention \\
\hline \multirow[t]{7}{*}{ Oats } & Weeds & Regular weeding \\
\hline & $\begin{array}{l}\text { Weather/frost/too much } \\
\text { rain/drought }\end{array}$ & Proper timing \\
\hline & Seeds expensive & $\begin{array}{l}\text { Avail affordable seeds/planting } \\
\text { material at agrovets }\end{array}$ \\
\hline & Low quality & Use certified seeds \\
\hline & Lack of seeds & $\begin{array}{l}\text { Avail seeds/planting material } \\
\text { at agrovets }\end{array}$ \\
\hline & At times does not germinate & Use certified seed \\
\hline & Lack of storage & Construct proper storage \\
\hline Forage sorghum & Eaten by birds & $\begin{array}{l}\text { Plant close to the homestead } \\
\text { Use scare crow }\end{array}$ \\
\hline \multirow[t]{6}{*}{ Sweet potato vines } & $\begin{array}{l}\text { Planting material/seeds not } \\
\text { available }\end{array}$ & $\begin{array}{l}\text { Avail seeds/planting material } \\
\text { at agrovets }\end{array}$ \\
\hline & Inadequate land & \\
\hline & Planting material not available & $\begin{array}{l}\text { Avail affordable seeds/planting } \\
\text { material }\end{array}$ \\
\hline & Require fencing & Fence the area \\
\hline & How to store & $\begin{array}{l}\text { More training on silage } \\
\text { making }\end{array}$ \\
\hline & Pests and diseases & $\begin{array}{l}\text { Ministry of Agriculture should } \\
\text { intervene }\end{array}$ \\
\hline
\end{tabular}


Table 54: Constraints experienced in production of different feed practices

\begin{tabular}{|l|l|l|l|}
\hline Problem & $\begin{array}{l}\text { Silage } \\
(\mathrm{n}=20)\end{array}$ & $\begin{array}{l}\text { Hay } \\
(\mathrm{n}=16)\end{array}$ & $\begin{array}{l}\text { Feed formulation } \\
(\mathrm{n}=6)\end{array}$ \\
\hline & \multicolumn{2}{|l|}{ \# of farmers } \\
\hline High cost of inputs & 12 & 4 & 2 \\
\hline Labour Intensive & 5 & 10 & 4 \\
\hline Lack of storage & 1 & 2 & 0.0 \\
\hline Weather (rain) & 2 & 0.0 & 0.0 \\
\hline
\end{tabular}

Table 55: Proposed interventions to constraints related to the production of feed practices

\begin{tabular}{|l|l|l|}
\hline Technology & Constraint & Proposed intervention \\
\hline \multirow{5}{*}{ Silage-making } & Lack of materials & Make silage bags available \\
\cline { 2 - 3 } & Lack of technical knowledge & More training \\
\cline { 2 - 3 } & Rots if not properly conserved & More training \\
\cline { 2 - 3 } & Requires skilled labour & More training \\
\cline { 2 - 3 } & Pests (rats/moles) & Avail quality silage bags \\
\hline Hay baling & Labour intensive & Use hay boxes \\
\hline Sunflower cake & Eaten by birds & Use scare crow \\
\hline Maize stover & Lack of machine for chopping & $\begin{array}{l}\text { PO explore subsidizing cost of } \\
\text { chaff cutters }\end{array}$ \\
\hline Ration formulation & Lack of technical knowledge & More training \\
& & \\
\hline
\end{tabular}




\subsection{Constraints experienced in the utilization of feeds/feed practices and proposed interventions}

Table 56: Constraints experienced in the utilization of grasses

\begin{tabular}{|l|l|l|l|l|}
\hline Problem & $\begin{array}{l}\text { Napier } \\
\text { grass } \\
(\mathrm{n}=147)\end{array}$ & $\begin{array}{l}\text { Boma } \\
\text { Rhodes } \\
(\mathrm{n}=76)\end{array}$ & $\begin{array}{l}\text { Columbus } \\
\text { grass } \\
(\mathrm{n}=14)\end{array}$ & $\begin{array}{l}\text { Nandi setaria } \\
(\mathrm{n}=5)\end{array}$ \\
\hline & \multicolumn{3}{|c|}{ Percentage of farmers } \\
\hline Wastage during feeding & 25.9 & 31.6 & 7.1 & 0 \\
\hline Labour intensive (requires chopping) & 10.9 & 6.6 & 0.0 & 0 \\
\hline Needs supplements/additives & 9.6 & 2.6 & 0.0 & 0 \\
\hline Irritating when harvesting & 7.5 & 0.0 & 0.0 & 0 \\
\hline Bulky & 6.8 & 3.9 & 0.0 & 0 \\
\hline Long processing & 5.4 & 3.9 & 0.0 & 40 \\
\hline Lack of machinery (requires machine) & 4.7 & 2.6 & 0.0 & 0 \\
\hline Inputs & 4.1 & 1.3 & 0.0 & 0 \\
\hline Lack of storage/poor storage & 4.7 & 26.3 & 71.4 & 20 \\
\hline Causes bloat & 2.7 & 0.0 & 0.0 & 0 \\
\hline Causes diarrhoea in animals & 2.7 & 0.0 & 0.0 & 0 \\
\hline Expensive & 2.7 & 0.0 & 0.0 & 0 \\
\hline Lack of technical knowledge & 2.0 & 7.9 & 0.0 & 0 \\
\hline Conservation & 1.4 & 0.0 & 7.1 & 20 \\
\hline Lack of silage bags & 1.4 & 0.0 & 0.0 & 0 \\
\hline Poor nutrition & 1.4 & 1.3 & 0.0 & 0 \\
\hline Not reliable & 1.4 & 0.0 & 0.0 & 0 \\
\hline Unpalatable & 1.4 & 7.9 & 14.3 & 20 \\
\hline Requires drying & 0.7 & 2.6 & 0.0 & 0 \\
\hline Lack of feed troughs & 0.7 & 1.3 & 0.0 & 0 \\
\hline Not efficient & 0.7 & 0.0 & 0.0 & 0 \\
\hline Timing in feeding & 0.7 & 0.0 & 0.0 & 0 \\
\hline Transport & 0.7 & 0.0 & 0.0 & 0 \\
\hline & & & & 0 \\
\hline
\end{tabular}

Constraints experienced in the utilization of grasses included labour, bloat, irritation when harvesting, diarrhoea among others listed in Table 56. The main constraint for Napier and Boma Rhodes grass was wastage during feeding. This was followed by lack of storage facilities for Boma Rhodes. For Columbus, the main problem was lack of storage facilities while for Nandi setaria famers had a problem with processing. Proposed interventions include hiring labourers, having proper storage facilities, among other interventions (Table 57). 
Table 57: Proposed interventions to constraints related to the utilization of grasses

\begin{tabular}{|c|c|c|}
\hline Technology & Constraint & Proposed intervention \\
\hline \multirow[t]{14}{*}{ Napier grass } & Labour intensive & Hire labourers \\
\hline & Lack of silage bags/expensive & Use cheap bags \\
\hline & Lack of storage & More/proper storage facilities \\
\hline & Needs supplementation & Mix with other feeds \\
\hline & Lack of knowledge in making silage & More training \\
\hline & Causes bloat & $\begin{array}{l}\text { More training } \\
\text { Do not feed directly after cutting/need wilting }\end{array}$ \\
\hline & Wastage during feeding/chopping & $\begin{array}{l}\text { Acquire chaff cutter/machine } \\
\text { Use feed troughs }\end{array}$ \\
\hline & Too dry & Mix with other feeds \\
\hline & Poor nutrition & Mix with other feeds \\
\hline & Lack of machine for chopping & Acquire chaff cutter/machine \\
\hline & Causes diarrhoea when fed immature & Feed when mature (3-4ft) \\
\hline & Chopping machine expensive & Raise money as group to buy pulveriser \\
\hline & Too watery when wet & Wilt before feeding to cow \\
\hline & When overgrown loses nutrients & Harvest at $3-4 \mathrm{ft}$ \\
\hline \multirow[t]{9}{*}{ Boma Rhodes } & Labour intensive & $\begin{array}{l}\text { Hire labourers } \\
\text { Have storage facilities }\end{array}$ \\
\hline & Lack of storage & Construct storage facilities \\
\hline & Needs supplementation & Mix with other feeds \\
\hline & Wastage during feeding/chopping & Use feed troughs \\
\hline & Too dry & Mix with other feeds \\
\hline & Chopping machine expensive & Provision of loans to purchase machine \\
\hline & Pests during storage & Construct proper storage facilities \\
\hline & Cow may refuse to eat & Mix with other feeds \\
\hline & Lack of knowledge on baling & More training \\
\hline \multirow[t]{2}{*}{ Columbus grass } & Lack of storage & Construct proper storage facilities \\
\hline & Cow may refuse to eat & Mix with other feeds \\
\hline \multirow[t]{2}{*}{ Nandi Setaria } & Lack of storage & Construct proper storage facilities \\
\hline & Needs processing & Raise money as group to buy pulveriser \\
\hline Sudan grass & Taints milk when given fresh & Wilt before feeding \\
\hline
\end{tabular}


Table 58: Constraints in utilization of oats, sweet potato vines, forage sorghum, desmodium and lucerne.

\begin{tabular}{|l|l|l|l|l|l|}
\hline & $\begin{array}{l}\text { Oats } \\
(\mathrm{n}=48)\end{array}$ & $\begin{array}{l}\text { Sweet potato } \\
\text { vines }(\mathrm{n}=17)\end{array}$ & $\begin{array}{l}\text { Forage } \\
\text { sorghum } \\
(\mathrm{n}=17)\end{array}$ & $\begin{array}{l}\text { Lucerne } \\
(\mathrm{n}=11)\end{array}$ & $\begin{array}{l}\text { Desmodium } \\
(\mathrm{n}=6)\end{array}$ \\
\hline Constraints & \multicolumn{5}{|c|}{ Percenge of farmers } \\
\hline $\begin{array}{l}\text { Lack of storage/poor } \\
\text { storage }\end{array}$ & 18.9 & 0.0 & 0.0 & 0.0 & 0.0 \\
\hline $\begin{array}{l}\text { Needs } \\
\text { supplements/additives }\end{array}$ & 16.7 & 0.0 & 5.9 & 0.0 & 0.0 \\
\hline Labour intensive & 12.5 & 5.9 & 11.8 & 0.0 & 0.0 \\
\hline Wastage during feeding & 12.5 & 0.0 & 11.8 & 0.0 & 0.0 \\
\hline Conservation problem & 8.3 & 11.7 & 0.0 & 9.1 & 0.0 \\
\hline Long processing & 8.3 & 11.7 & 11.8 & 0.0 & 16.7 \\
\hline Causes bloat & 6.3 & 0.0 & 0.0 & 36.4 & 0.0 \\
\hline Unpalatable & 6.3 & 0.0 & 17.6 & 9.1 & 33.3 \\
\hline Expensive & 4.2 & 0.0 & 0.0 & 0.0 & 0.0 \\
\hline Lack of machinery & 4.2 & 0.0 & 0.0 & 0.0 & 0.0 \\
\hline Causes diarrhoea & 2.1 & 0.0 & 0.0 & 0.0 & 0.0 \\
\hline Bulky & 0.0 & 23.5 & 23.5 & 9.1 & 0.0 \\
\hline $\begin{array}{l}\text { Lack of } \\
\text { knowledge }\end{array}$ & 0.0 & 17.6 & 5.9 & 18.2 & 0.0 \\
\hline Low yields & 0.0 & 5.9 & 0.0 & 0.0 & 16.7 \\
\hline $\begin{array}{l}\text { Causes toxicity if fed in } \\
\text { excess }\end{array}$ & 0.0 & 0.0 & 11.8 & 0.0 & 0.0 \\
\hline Taints milk & 0.0 & 23.5 & 0.0 & 0.0 & 0.0 \\
\hline Weather & 0.0 & 0.0 & 0.0 & 18.2 & 18.7 \\
\hline Seasonal & 0.0 & 0.0 & 0.0 & 0.0 & 16.7 \\
\hline
\end{tabular}

The main constraint in the utilization of oats was lack of storage facilities (Table 58). The main constraint with sweet potato was the fact that it tainted milk when fed to livestock while lucerne caused bloat according to 36.4 percent of farmers. Forage sorghum was said to be bulky by 23.5 percent of the farmers. Proposed interventions included constructing proper storage facilities and raising money as a group to buy pulverizers (Table 59). The problem of tainting milk caused by sweet potato vines and bloat when livestock is fed with lucerne can be solved by wilting and also mixing with other feeds. 
Table 59: Proposed interventions to constraints related to the utilization of oats, sweet potato vines, forage sorghum, desmodium and lucerne

\begin{tabular}{|c|c|c|}
\hline Technology & Constraint & Proposed intervention \\
\hline \multirow[t]{10}{*}{ Oats } & Gets spoiled if not properly conserved & Construct proper storage facilities \\
\hline & Labour intensive & Raise money as a group to buy pulverizer \\
\hline & Lack of storage/poor storage & Construct proper storage facilities \\
\hline & Wastage during feeding/chopping & Use feed troughs \\
\hline & Lack of machine & Raise money as a group to buy pulverizer \\
\hline & Lack of knowledge on conservation & More training \\
\hline & Bad smell & Add additives such as molasses \\
\hline & Pests during storage & More training on pest control \\
\hline & Cow may refuse to eat & Train cow to eat \\
\hline & Long processing & Raise money as group to buy pulverizer \\
\hline \multirow[t]{3}{*}{ Sweet potato vines } & Labour intensive & Acquire chaff cutter/machine \\
\hline & Lack of knowledge in making silage & More training in silage-making \\
\hline & Taints milk when given a lot & Give in small portions \\
\hline \multirow[t]{4}{*}{ Forage sorghum } & Lack of storage & Construct proper storage facilities \\
\hline & Wastage during feeding/chopping & Use feed troughs \\
\hline & Needs processing & Acquire chaff cutter/machine \\
\hline & Cow may refuse to eat & Train cow to learn to eat \\
\hline \multirow[t]{5}{*}{ Lucerne } & Causes bloat & $\begin{array}{l}\text { More training, mix with other feeds, give } \\
\text { in small portions and wilt }\end{array}$ \\
\hline & Lack of knowledge on feed ratio & More training on feed rationing \\
\hline & Lack of knowledge on conservation & More training on conservation \\
\hline & Unpalatable & Mix with other feeds \\
\hline & Taints milk when given fresh & Wilt before feeding to cow \\
\hline \multirow[t]{2}{*}{ Desmodium } & Low yields & Increase acreage \\
\hline & Unpalatable (Cow may refuse to eat) & Train cow to learn to eat \\
\hline \multirow[t]{3}{*}{ Fodder shrubs } & Needs processing & Acquire machine \\
\hline & Cow may refuse to eat & Mix with other feeds \\
\hline & Causes toxicity when given a lot & Give in small quantities \\
\hline
\end{tabular}


Table 60: Constraints in utilization of crop residues

\begin{tabular}{|c|c|c|c|c|}
\hline & $\begin{array}{l}\text { Maize stover } \\
\text { green }(n=50)\end{array}$ & $\begin{array}{l}\text { Maize } \\
\text { stover dry } \\
n=36\end{array}$ & $\begin{array}{l}\text { Bean husks } \\
n=16\end{array}$ & $\begin{array}{l}\text { Wheat/millet } \\
\text { straw }(n=17)\end{array}$ \\
\hline Wastage during feeding & 28 & 27.8 & 18.8 & 17.6 \\
\hline Requires processing & 14 & 0.0 & 6.3 & 5.9 \\
\hline Lack of machinery & 12 & 8.3 & 6.3 & 0.0 \\
\hline $\begin{array}{l}\text { Lack of storage/poor } \\
\text { storage }\end{array}$ & 14 & 5.6 & 12.6 & 17.6 \\
\hline Bulky & 8 & 2.8 & 0.0 & 0.0 \\
\hline Conservation problem & 6 & 0.0 & 0.0 & 14.3 \\
\hline $\begin{array}{l}\text { Needs } \\
\text { additives/supplements }\end{array}$ & 6 & 36.1 & 48.8 & 0.0 \\
\hline Unpalatable & 6 & 2.8 & 0.0 & 0.0 \\
\hline Labour intensive & 4 & 2.8 & 6.3 & 5.9 \\
\hline $\begin{array}{l}\text { Lack of technical } \\
\text { knowledge }\end{array}$ & 2 & 5.6 & 6.3 & 0.0 \\
\hline Inputs & 0 & 2.8 & 0.0 & 14.3 \\
\hline Lack of silage bags & 0 & 0.0 & 0.0 & 5.9 \\
\hline Low yields & 0 & 2.8 & 0.0 & 5.9 \\
\hline Taints milk & 0 & 0.0 & 0.0 & 5.9 \\
\hline Indigestion & 0 & 2.8 & 0.0 & 0.0 \\
\hline Pests & 0 & 0.0 & 0.0 & 5.9 \\
\hline
\end{tabular}


The main constraints in the utilization of crop residues included wastage during feeding, processing, lack of machinery and storage (Table 60). Proposed interventions included using troughs during feeding to avoid wastage, constructing good storage facilities, using a chaff cutter to chop and raising money as a group to buy machinery for processing (Table 61).

Table 61: Proposed interventions to constraints related to the utilization of crop residues and other feed practices

\begin{tabular}{|c|c|c|}
\hline & Constraint & Proposed intervention \\
\hline \multirow[t]{2}{*}{ Maize stover green } & Wastage during feeding/chopping & Use feed troughs \\
\hline & Poor storage & More training \\
\hline \multirow[t]{9}{*}{ Maize stover dry } & Labour intensive & Hire labourers \\
\hline & Lack of storage/poor storage & Construct proper storage \\
\hline & Needs supplementation & Mix with molasses and other feeds \\
\hline & Wastage during feeding/chopping & Acquire chaff cutter/machine, use feed troughs \\
\hline & Too dry & Mix with other feeds \\
\hline & Lack of machine/expensive & Raise money as group to buy machine \\
\hline & Difficult to chop when dry & Use sharp 'panga' (machete) \\
\hline & Requires chopping/processing & Use chaff cutter \\
\hline & Seasonal & More/proper storage facilities \\
\hline \multirow[t]{5}{*}{ Bean husks } & Lack of storage & More/proper storage facilities \\
\hline & Needs supplementation & Mix with other feeds \\
\hline & Wastage during feeding/chopping & Use feed troughs \\
\hline & Too dry & Mix with other feeds \\
\hline & Cow may refuse to eat & Train cow to eat \\
\hline Sunflower cake & Needs processing & Raise money as a group to buy a pulveriser \\
\hline \multirow[t]{3}{*}{ Silage } & Lack of silage bags & Use cheap/affordable bags \\
\hline & Lack of machine & Provision of loans to purchase machine \\
\hline & Poor storage & Proper storage facilities \\
\hline \multirow[t]{3}{*}{ Hay } & Lack of storage/poor storage & More/proper storage facilities/more training \\
\hline & Wastage during feeding/chopping & Use feed troughs \\
\hline & Lack of machine & Raise money as group to buy pulveriser \\
\hline Wheat straw & Poor storage & More training on conservation \\
\hline Feed rationing & Lack of knowledge on proper rations & More training \\
\hline
\end{tabular}




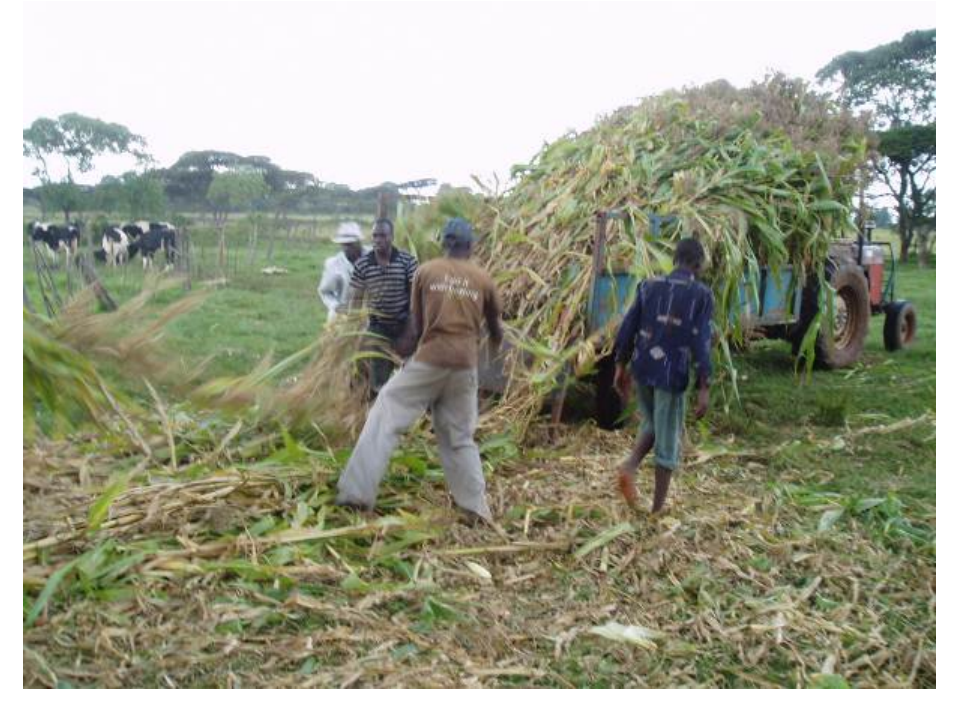

Green maize stover

\subsection{Feed selling}

Farmers were asked whether they had sold any feeds during the last 12 months and the quantities sold. Metkei PO had the highest percentage of farmers who had sold feeds at slightly over 40 percent (Figure 2). Other sites that had over 30 percent of farmers who had sold feeds were Siongiroi and Taragoon. None of the farmers in Cherobu sold any livestock feed. Out of the famers who sold feeds, 22 percent were male farmers while females were 19 percent.

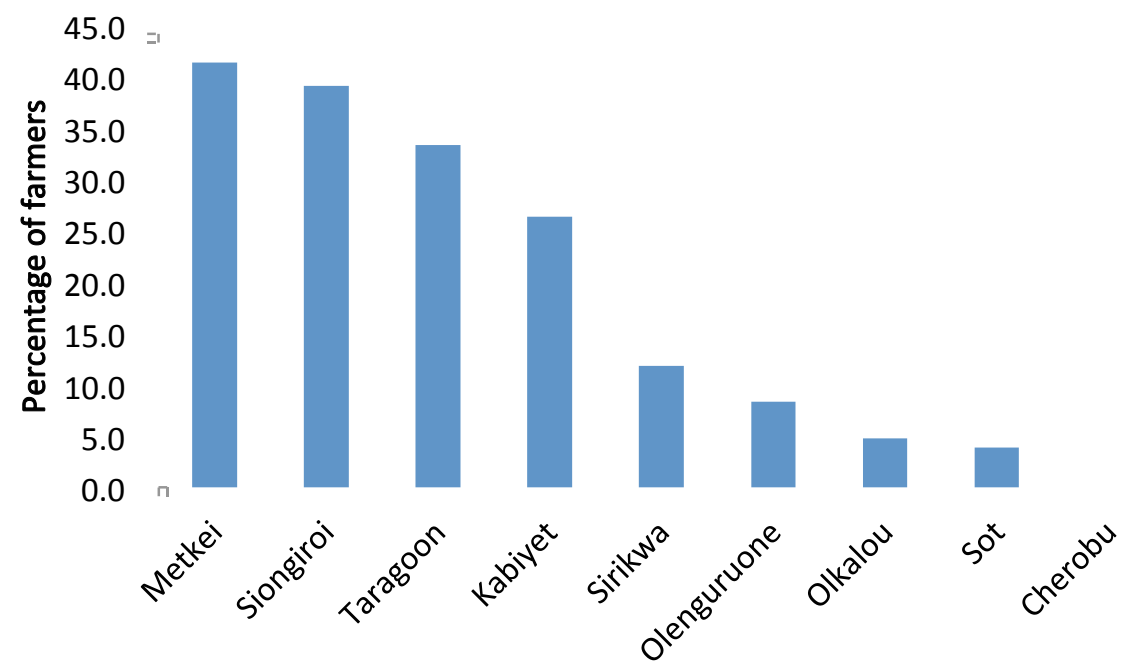

Figure 2: Percentage of farmers across sites that sold livestock feed 
The amount of feed sold depended on the type of feed. The unit of measurement also varied. For instance, Napier was sold in kilogrammes, Boma Rhodes by bales and gunny bags and oats by $90 \mathrm{~kg}$ bags (Table 62). Oats had been sold by the highest number of farmers, followed by Boma Rhodes.

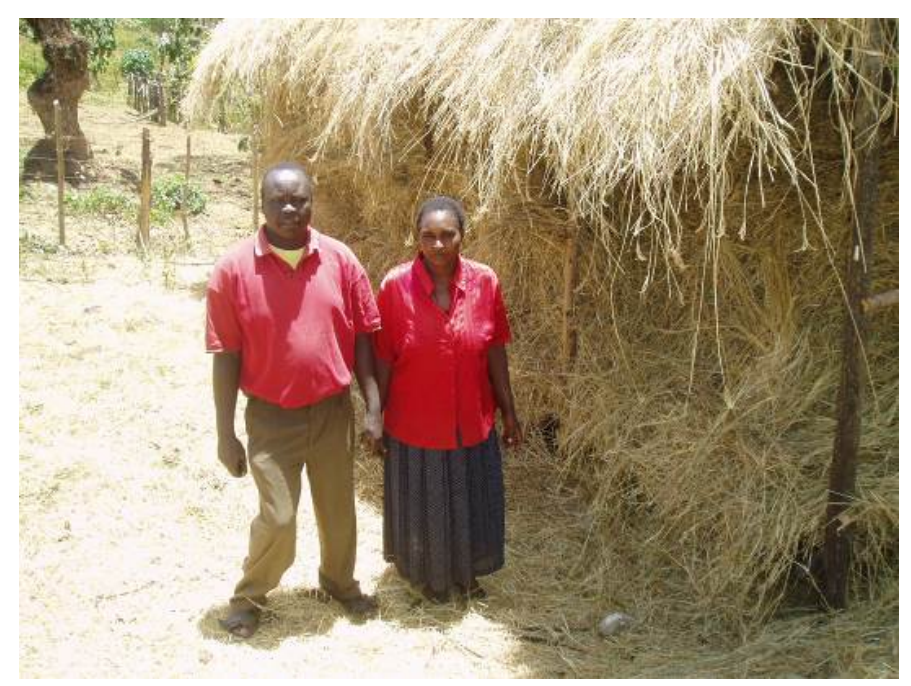

A couple in Rift Valley next to stored Boma Rhodes

Table 62: Number of farmers selling each feed and the average quantities

\begin{tabular}{|l|r|r|}
\hline Variable & $\mathrm{n}$ & \multicolumn{2}{|c|}{ Quantity (Mean) } \\
\hline Napier (kg) & 1 & 1000.0 \\
\hline Boma Rhodes (bales) & 12 & 46.1 \\
\hline Oats (bags) & 15 & 68.1 \\
\hline Maize green stover (sack) & 1 & 2.0 \\
\hline Maize dry stover (sacks) & 3 & 13.7 \\
\hline Columbus grass seeds (kg) & 1 & 5.0 \\
\hline Bean husks (sacks) & 1 & 10.0 \\
\hline Boma Rhodes grass (sacks) & 1 & 5.0 \\
\hline Nandi setaria (sacks) & 1 & 2.0 \\
\hline Sunflower cake (sacks) & & 5.0 \\
\hline
\end{tabular}

$\mathrm{n}=$ the number of farmers selling each feed 
Table 63: Mean price at which each type of feed is sold

\begin{tabular}{|l|c|c|}
\hline Variable & $\mathrm{n}$ & $\begin{array}{c}\text { Mean } \\
\text { price } \\
\text { (Ksh) }\end{array}$ \\
\hline Napier (1000 kg) & 1 & 5000 \\
\hline Boma Rhodes (bales) & 12 & 295.8 \\
\hline Oats & 13 & 576.9 \\
\hline Maize stover (green, per sack) & 1 & 200.0 \\
\hline Maize stover (dry, per sack) & 4 & 160.0 \\
\hline *Columbus grass seeds & 1 & 100 \\
\hline Hay & 3 & 383.3 \\
\hline Bean husks (sack) & 1 & 150.0 \\
\hline **Rhodes grass & 1 & 100 \\
\hline Nandi setaria (sack) & 1 & 200.0 \\
\hline Sunflower cake (sack) & 1 & 250.0 \\
\hline Dairymeal (1 large amt.) & 1 & 1500.0 \\
\hline
\end{tabular}

$\mathrm{n}=$ number of households that responded to the question

*Columbus grass: KES 100 for $5 \mathrm{~kg}$ and KES 3000 for 0.15 acres

**Rhodes grass: KES 100 for $5 \mathrm{~kg}$ and KES 5000 for 0.5 acres

Oats: 1 acre for 5000

Dairy meal: Large quantity for KES 1500 
Table 64: Feed sale and profitability

\begin{tabular}{|c|c|c|c|c|c|c|}
\hline & All & & Male & & Female & \\
\hline & $\mathrm{n}$ & $\%$ & $\mathrm{n}$ & $\%$ & $\mathrm{n}$ & $\%$ \\
\hline Sale was profitable (yes) & 35 & 92.1 & 23 & 95.8 & 12 & 85.7 \\
\hline \multicolumn{7}{|l|}{ Reason why profitable } \\
\hline $\begin{array}{lll}\text { High returns } & \text { compared } & \text { to } \\
\text { production costs } & & \end{array}$ & 30 & 88.2 & 20 & 90.9 & 10 & 83.3 \\
\hline \multicolumn{7}{|l|}{ Reason not profitable } \\
\hline High production cost & 2 & 5.9 & & 0.0 & 2 & 16.7 \\
\hline Low demand & 2 & 5.9 & 2 & 9.1 & & 0.0 \\
\hline \multicolumn{7}{|l|}{ Why did not sell } \\
\hline Enough for own livestock & 83 & 72.2 & 50 & 70.4 & 33 & 75.0 \\
\hline Small size of land & 11 & 9.6 & 7 & 9.9 & 4 & 9.1 \\
\hline No surplus & 21 & 18.3 & 14 & 19.7 & 7 & 15.9 \\
\hline
\end{tabular}


Table 65: Type of feeds to be sold in future

\begin{tabular}{|l|r|r|r|}
\hline & All (n=181) & $\begin{array}{l}\text { Male } \\
(\mathrm{n}=109)\end{array}$ & Female (n=72) \\
\hline Feed & \multicolumn{3}{|c|}{ Percentage of farmers } \\
\hline Boma Rhodes & 33.6 & 31.25 & 37.3 \\
\hline Oats & 20.0 & 22.5 & 16.9 \\
\hline Napier & 10.7 & 11.25 & 10.2 \\
\hline Hay & 5.7 & 7.5 & 3.4 \\
\hline Maize stover dry & 5.0 & 5 & 5.1 \\
\hline Lucerne & 3.6 & 3.75 & 3.4 \\
\hline Columbus grass & 2.9 & 1.25 & 5.1 \\
\hline Sweet potato vines & 2.1 & 2.5 & 1.7 \\
\hline Nandi setaria & 2.1 & 2.5 & 1.7 \\
\hline Forage sorghum & 1.4 & 2.5 & 0.0 \\
\hline Silage & 1.4 & 1.25 & 1.7 \\
\hline Maize stover green & 0.7 & 0 & 1.7 \\
\hline Desmodium & 0.7 & 0 & 1.7 \\
\hline Sudan grass & 0.7 & 0 & 1.7 \\
\hline Coloured guinea & 0.7 & 1.25 & 0.0 \\
\hline Sweet potato vines & 0.7 & 0 & 0.0 \\
\hline Calliandra & 0.7 & 1.25 & 0.0 \\
\hline Bean husks & 0.7 & 0 & 1.7 \\
\hline
\end{tabular}

\subsection{Future plans}

When asked about their future plans regarding feeds, slightly less than half the farmers wanted to increase feed production (Table 66). This was followed by increasing land acreage for feeds. Strategies for increasing feed production included expanding acreage of land and acquiring loans (Table 67). 
Table 66: Future plans

\begin{tabular}{|c|c|c|c|}
\hline Future plans & $\begin{array}{l}\text { All } \\
(\mathrm{n}=181)\end{array}$ & $\begin{array}{l}\text { Male } \\
(\mathrm{n}=109)\end{array}$ & $\begin{array}{l}\text { Female } \\
(\mathrm{n}=72)\end{array}$ \\
\hline & $\begin{array}{l}\% \text { of } \\
\text { farmers }\end{array}$ & & \\
\hline Increase feed production & 49.2 & 48.6 & 50.0 \\
\hline Increase land acreage for feeds & 28.7 & 26.6 & 31.9 \\
\hline Expand storage facility & 19.3 & 18.3 & 20.8 \\
\hline Introduce variety of feeds & 18.8 & 21.1 & 15.3 \\
\hline Acquire machinery/chaff cutter & 8.3 & 10.1 & 5.6 \\
\hline Put up zero grazing unit & 4.4 & 5.5 & 2.8 \\
\hline Use certified seeds & 3.9 & 3.7 & 4.2 \\
\hline Use modern technology & 3.9 & 6.4 & 0.0 \\
\hline Attend more trainings & 3.3 & 2.8 & 4.2 \\
\hline $\begin{array}{l}\text { Improve breeding through artificial } \\
\text { insemination }\end{array}$ & 3.3 & 0.0 & 8.3 \\
\hline Add more cows & 2.2 & 2.8 & 1.4 \\
\hline Produce for commercial purposes & 1.7 & 2.8 & 0.0 \\
\hline Switch from cash crops to dairy & 1.1 & 1.8 & 0.0 \\
\hline Becoming a model farmer & 0.6 & 0.0 & 1.4 \\
\hline Fencing the land & 0.6 & 0.9 & 0.0 \\
\hline Hire management staff & 0.6 & 0.0 & 1.4 \\
\hline Start feed processing & 0.6 & 0.9 & 0.0 \\
\hline
\end{tabular}


Table 67: Strategies to increase production of livestock feeds

\begin{tabular}{|c|c|c|c|c|}
\hline & $\begin{array}{l}\text { All } \\
(n=181)\end{array}$ & $\begin{array}{l}\text { Male } \\
(n=109)\end{array}$ & $\begin{array}{l}\text { Female } \\
(n=72)\end{array}$ & $\begin{array}{l}\text { All } \\
(n=181)\end{array}$ \\
\hline & \multicolumn{4}{|c|}{ Percentage of farmers } \\
\hline Expand land acreage of fallow land & 30.9 & 29.4 & 33.3 & 30.9 \\
\hline Acquire loans & 22.7 & 23.9 & 20.8 & 22.7 \\
\hline $\begin{array}{l}\text { Attend more trainings and exchange } \\
\text { visits }\end{array}$ & 11.0 & 10.1 & 12.5 & 11.0 \\
\hline $\begin{array}{l}\text { Source for information and technical } \\
\text { knowledge }\end{array}$ & 10.5 & 8.3 & 13.9 & 10.5 \\
\hline Buy certified seeds and plant on farm & 10.5 & 11.0 & 9.7 & 10.5 \\
\hline Proper management & 8.3 & 7.3 & 9.7 & 8.3 \\
\hline $\begin{array}{l}\text { Upgrade cattle through artificial } \\
\text { insemination }\end{array}$ & 7.2 & 8.3 & 5.6 & 7.2 \\
\hline Plant using latest technology & 6.1 & 6.4 & 5.6 & 6.1 \\
\hline Acquire processing machines & 5.5 & 7.3 & 2.8 & 5.5 \\
\hline Rent land & 5.0 & 6.4 & 2.8 & 5.0 \\
\hline Hire casual workers & 4.4 & 3.7 & 5.6 & 4.4 \\
\hline Attending field days and ASK shows & 3.9 & 3.7 & 4.2 & 3.9 \\
\hline Use capital from sales & 2.8 & 3.7 & 1.4 & 2.8 \\
\hline Build storage facilities & 2.2 & 0.9 & 4.2 & 2.2 \\
\hline Switch from cash crops & 1.7 & 1.8 & 1.4 & 1.7 \\
\hline Acquire more improved livestock & 1.7 & 1.8 & 1.4 & 1.7 \\
\hline Plant Napier on boundaries & 1.1 & 0.9 & 1.4 & 1.1 \\
\hline Use savings & 0.6 & 0.9 & 0.0 & 0.6 \\
\hline Reduce grazing land & 0.6 & 0.0 & 1.4 & 0.6 \\
\hline Practice intensive dairy farming & 0.6 & 0.0 & 1.4 & 0.6 \\
\hline Plant sunflower after harvesting crops & 0.6 & 0.0 & 1.4 & 0.6 \\
\hline Availability of capital & 0.6 & 0.9 & 0.0 & 0.6 \\
\hline
\end{tabular}




\section{Motivation for increasing acreage of feeds}

About 49.2 percent of farmers interviewed indicated that they wanted to increase feed production and another 28.7 percent indicated they wanted to increase acreage under feed technologies/practices (Table 66). Disaggregating data by gender, 29.4 percent of male farmers and 33.3 percent of female farmers wanted to increase acreage and utilization of feed. The main motivation for increasing acreage of feeds was that there had been an increase in milk production (Table 68). This was mentioned by slightly over half of the sampled farmers with more females than males citing it as a reason. High returns from dairy products was the second reason mentioned by both male and female farmers.

Table 68: Motivation to increase acreage of feeds

\begin{tabular}{|l|r|r|r|}
\hline Reason & \multicolumn{1}{|c|}{$\begin{array}{c}\text { All farmers } \\
(\mathrm{n}=181)\end{array}$} & \multicolumn{1}{|c|}{$\begin{array}{c}\text { Male } \\
(\mathrm{n}=109)\end{array}$} & $\begin{array}{r}\text { Female } \\
(\mathrm{n}=72)\end{array}$ \\
\hline & \multicolumn{3}{|c|}{$\begin{array}{r}\text { of farmers } \\
\hline \text { Increased milk production }\end{array}$} \\
\hline High returns from dairy products & 21.0 & 46.7 & 55.6 \\
\hline Availability of ready market for dairy products & 13.3 & 14.7 & 18.06 \\
\hline Acquired more livestock & 12.2 & 13.8 & 9.72 \\
\hline Feed livestock during dry season & 7.7 & 4.6 & 12.50 \\
\hline For commercial purposes & 7.7 & 10.1 & 4.17 \\
\hline Acquired technical knowledge & 5.5 & 5.5 & 5.56 \\
\hline Dairy farming is profitable & 5.5 & 5.5 & 5.56 \\
\hline High returns from sale of feeds & 4.4 & 3.7 & 5.56 \\
\hline Availability of land & 2.8 & 3.7 & 1.39 \\
\hline Demand for quality feeds & 2.8 & 4.6 & 0.00 \\
\hline Good milk prices from PO & 2.2 & 1.8 & 2.78 \\
\hline Introduction of different variety of feeds & 1.7 & 0.9 & 2.78 \\
\hline Reduced prices of purchasing dairy cows & 1.7 & 2.8 & 0.00 \\
\hline Set up of semi-zero grazing unit & 1.7 & 2.8 & 0.00 \\
\hline Favourable climate & 0.6 & 0.0 & 1.39 \\
\hline Fertile soils & 0.6 & 0.0 & 1.39 \\
\hline
\end{tabular}




\subsection{Discussion, conclusion and recommendations}

The findings of this study have shown that dairy farmers in the study sites were all aware of improved livestock feed practices disseminated by the EADD project and other institutions. Awareness of a technology is the first step towards uptake. Once farmers are aware of a technology, then the next logical step is to make a decision on whether to take it up or not. The level of awareness varied from technology to technology with over 70 percent of farmers being aware of pasture grasses such as Napier and Boma Rhodes and herbaceous legumes such as lucerne. Regarding uptake, farmers have adopted various livestock feed practices ranging from improved pasture grasses, herbaceous legumes, fodder shrubs, crop by products, crop residues, feed conservation technologies, concentrates and other fodder crops such as oats, forage sorghum and sweet potato vines. The level of adoption however varied from technology to technology. Napier grass had the highest adoption Except for Napier grass, there were big discrepancies between awareness and adoption of other practices. For example, slightly over 30 percent of farmers who were aware of Boma Rhodes had not adopted it. The percentage was even higher for herbaceous fodder legumes and fodder shrubs. Why does Napier grass have a high uptake while fodder legumes have low uptake? What lessons can we learn about Napier adoption that can be applied to fodder legumes to enhance their uptake? In terms of species preference, Napier grass also ranked highest. What factors do farmers consider? Other findings of this study also give insights on constraints that farmers face in production and utilization of livestock feed practices and their future plans. Below is a critical analysis of the reasons for the low and high uptake of improved legume forages and Napier grass respectively, farmers' preferences, constraints experienced in production and utilization of preferred species, and their future plans.

\section{Understanding the low adoption of herbaceous fodder legumes}

Herbaceous fodder legumes promoted by the EADD project and other institutions were mainly lucerne and desmodium. Less promoted were lupin, purple vetch and lablab. About 74 percent and 42 percent of farmers were aware of lucerne and desmodium respectively. However, only a paltry 12.7 percent and 9.4 percent of farmers in the study sites had adopted lucerne and desmodium respectively.

Why the low adoption? The low adoption of herbaceous fodder legumes in the tropics is not a new phenomenon. Reviews of adoption of tropical forage legumes around the world have revealed disappointing results (Thomas and Sumberg 1995, Elbasha et al 1999, Peters and Lascano 2003). In Kenya, several attempts have been made by different government projects to promote fodder legumes. These include the National Dairy Development Project (NDDP) which introduced two species of desmodium a decade ago (NDDP 1990). KARI also introduced fodder legumes in the 1990s (Wandera 1995). In the late 1990s, the Legume Research Network Project also introduced herbaceous legumes mainly for green manure. Since 2008, the EADD project has been promoting the use of herbaceous fodder legumes and other livestock feed practices in central and Rift Valley regions of Kenya. Despite these and many other attempts, adoption of forage 
legumes has been low in Kenya (Mwangi and Wambugu 2003). To explain the low adoption of fodder legumes, researchers have pointed to issues such as land tenure, labour, lack of reliable seed supply and associated costs, and lack of markets (Paterson et al1998, Elbasha et al 1999, Mwangi and Wambugu 2003). The lack of markets is not an issue in this study since farmers have a ready market for their milk. They supply their milk to chilling plants run by producer organizations.

When farmers were asked why they had not adopted the use of herbaceous fodder legumes, a high percentage of farmers cited lack of seed and planting material for lucerne and desmodium respectively. This was followed by high costs associated with seeds. Other reasons included lack of technical knowledge, poor performance on the farm, difficulty in establishment for lucerne, low yields and labour. It is clear from this study that the main reasons are to do with the availability and associated costs of seeds. This is a perennial problem that has been reported by most studies that have reviewed the adoption of herbaceous fodder legumes. When asked where their sources of planting material were from, neighbours, EADD project, KFA and agrovet shops were the most cited sources. Promotion of herbaceous fodder legumes has not been matched by the supply of seed and planting material. If these issues are not addressed, then adoption of fodder legumes will remain a mirage. Attempts have been made by the EADD project to encourage VFTs to host demonstration plots that serve a dual purpose of training and bulking seed/planting material, but judging from the findings of this study, availability of planting material still remains a challenge. Agrovets are selling lucerne seeds but cost has been cited as an impediment. If the issues of availability and cost are not addressed, then low adoption of the legume fodder technology will persist for a long time to come.

\section{Understanding the low adoption of fodder shrubs}

Fodder shrubs that have been promoted by EADD include Calliandra calorthysus, Leuceana trichandria, Sesbania sesban, tree lucerne and mulberry. Findings from this study have shown that despite the fact that 67.5 percent of farmers were aware of fodder shrubs, only 33.1 percent had planted them on their farms. Calliandra was the most commonly grown fodder shrub among the farmers surveyed. Reasons farmers gave for the low adoption included unavailability of planting material. It could also be due to the fact that farmers lack the skills to establish nurseries or if they do have the skills, they find it tedious to do it. This confirms the findings from farm survey reports that attributed poor adoption of fodder shrubs to lack of seed/seedlings (Mwangi and Wambugu 2003). Sources of seed/seedlings for calliandra are mainly the EADD project, ICRAF and private nurseries. The dependence on projects and organizations for the supply of seed is not sustainable. Mechanisms that are community based need to be developed to ensure a reliable supply of fodder shrub seeds/seedlings.

\section{Lessons from the high adoption of Napier grass}

In contrast to the low adoption of herbaceous fodder legumes and fodder shrubs, Napier grass has been adopted by 91.2 percent of the farmers interviewed. Reasons given for the high adoption 
included drought-tolerant ability for some varieties, high nutrition content, fast growth, easy to manage, high biomass, ability to regrow after harvest, palatability, evergreen, planting material easily available and the fact that it can be used to make silage. Napier grass has a long research and development history in Kenya. It has mainly been adopted in intensive farming systems where animals are stall-fed. Studies done in the 1980s and 1990s have shown that Napier grass is grown by over 70 percent of farmers in central Kenya (Stotz 1983, Bayer 1990, Staal et al 1998). The proportion has since gone up. When data in the current study was segregated by site, Olkalou, a site in central Kenya, recorded 90 percent of households planting Napier grass. The high adoption is therefore expected because of its agronomic qualities and the fact that planting material is easily available. Napier in Kenya is propagated mainly from cuttings. These could be in the form of root splits, canes with 3 nodes or whole canes. The main source for planting material for the farmers surveyed was other farmers and neighbours. It is no wonder that uptake of Napier was quite high as farmers can easily obtain planting material from their fellow farmers. Average acreage of Napier was 0.5 and therefore for a farmer to part with a few canes or root splits does not affect the overall productivity of the Napier. A study done by Kiptot and Franzel (2012) showed that some VFTs sold Napier canes to their fellow farmers at a small fee. This is in contrast to desmodium where the few farmers who had it on their farms planted it on very small portions, an average of 0.1 of an acre. Sharing vines of desmodium from these small plots may be a challenge. This observation is confirmed by a study undertaken by Sinja et al (2004) in central Kenya that showed that the amount of desmodium a farmer has on the farm had the greatest effect on both the extent and probability of giving out desmodium vines. A key lesson from Napier adoption is that making germplasm available at the farm/local level ensures sustainability of seed/planting material delivery mechanisms. Past research by Kiptot et al (2006) and Sinja et al (2004) has shown that farmers mostly share seed/planting material through their informal social networks.

\section{Farmer preferences of livestock feed practices}

The findings of this study have shown that the five most preferred livestock feed resources in order of importance are Napier, Boma Rhodes, dry maize stover, lucerne and oats. This suggests that more research and development attention should be given to these feed resources to ensure that farmers get maximum productivity. The main reasons for the preference of Napier were its drought-resistant ability, increases milk production, fast growth and easy to manage. Boma Rhodes was preferred because of the ability to increase milk production, fast growth, good for hay-making, high biomass and high nutrition content. Maize stover, a crop residue, was preferred because it can be stored for long, used during drought, and easy to manage. Lucerne was preferred because it is drought-resistant, is used as a protein supplement and increases milk production. Oats was preferred because it increases milk production, is a protein supplement, is grows fast and can be used during the dry season. The findings show that farmers not only consider agronomic attributes, management, nutritional content but also the availability of the fodder during the dry season. Napier, Boma Rhodes, oats and maize stover can be conserved for use during the dry season. During discussions with farmers, they indicated that surplus Napier and maize stover was usually ensilaged. The major agricultural activity on almost all the smallholders was arable cropping with maize forming the major crop. Maize is a staple crop in Kenya. Maize stover is therefore the most abundant arable by-product on all the smallholdings. 
According to Mwangi and Wambugu (2003), maize crop residues supply about 23 percent of dry matter available to dairy farmers in central Kenya. Farmers have learnt to store the residue for the dry season or make silage out of it. Farmers make hay out of surplus Boma Rhodes and oats. Lucerne is also said to be drought-tolerant and therefore available during the dry season.

\section{Constraints and opportunities in production of preferred livestock feed resources}

The main constraint that farmers experienced in the production of Napier and Boma Rhodes was labour. Considerable amount of labour is needed in establishment and weeding. Farmers used different methods to establish Napier. Some used the newly introduced 'tumbukiza' method which is considered labour intensive. The method entails the planting of Napier in round or rectangular pits $60-90 \mathrm{~cm}$ wide and $60-90 \mathrm{~cm}$ deep, filled with a mixture of topsoil and manure in the ratio of 1:2. Considerable labour is required to dig the pits. Once the Napier is established, the pits conserve moisture for longer periods and concentrate fertility at a point of easy use by the Napier grass resulting in higher productivity per unit area of land. Research conducted by Muyekho et al (2003) has shown that the tumbukiza method of planting Napier grass is superior to the conventional method in terms of herbage dry matter. Consequently, a study by Otieno et al (1999) demonstrated that 0.1 ha of Napier grass planted using the tumbukiza method could produce enough herbage to support one mature cow; in contrast, the conventional method would require 0.4 ha of land to produce a similar amount of fodder. The labour used appears to have a high economic return. Farmers should therefore be provided with the two options with clear facts so that they can make informed decisions on what method is convenient for them depending on their resource endowments. If labour is a major constraint, it is recommended that farmers use the conventional method with inorganic fertilizer. Where labour is not a major constraint, it is recommended that farmers use the tumbukiza method because it gives a higher net present value benefit:cost ratio. In order to maximize returns to labour, there is a need for researchers to further explore ways of intercropping Napier grass with food crops.

Weeding of Napier grass is also another labour-intensive activity. Weeding eliminates re-growth of undesirable plants and increases soil aeration. In order to avoid weeding regularly, farmers are advised to use close spacing to ensure that Napier quickly forms a closed canopy that suppresses weeds. Planting of forage legumes within Napier rows is also recommended to ensure that the forage legumes suppress weeds. However, Mwangi and Wambugu (2003) reported poor persistence of legumes such as Desmodium intortum when planted with Napier. Timing and spacing are therefore crucial when intercropping Napier with legumes. Future studies to address labour should aim at developing establishment and management methods that reduce labour requirements. Apart from labour constraints, some farmers indicated that they experienced establishment difficulties for Boma Rhodes when seeds are used. A few innovative farmers have tried using root splits which they consider to solve the problem of establishment. More research

on different methods for propagating Boma Rhodes need to be undertaken since it is one of the preferred livestock feed technologies. 
The main constraint in production of herbaceous legumes and fodder shrubs is unavailability of planting material. Land area occupied by desmodium is about 0.1 acres and lucerne about 0.9 acres while the average number of trees of fodder shrubs per household is 24 for leuceana, callindra 70 and tree lucerne 80 . This is way below the recommended 500 number of calliandra shrubs that are required to feed 1 cow per year (Wambugu et al 2011). What is not clear is whether unavailability of planting material was the reason for the low acreage/number of plants or not. As had been suggested earlier, community mechanisms to make seed/planting material should be given priority if high rates of adoption of forage legumes are to be achieved.

\section{Constraints and opportunities in the utilization of preferred livestock feed resources}

Constraints experienced in utilization of Napier include wastage during feeding, labour during chopping, and skin and throat irritation during harvesting caused by the prickly hairs. Proposed interventions by farmers included using feed troughs for feedings and a chaff cutter for chopping. The EADD project has trained farmers on how to use chaff cutters to reduce labour, however, this study has shown that only 12 percent of farmers have chaff cutters. This is due to the high cost. A suggestion given by farmers was to have them organized into groups and linked to micro-credit institutions. This will enable them get loans for purchasing machinery to reduce labour requirements. To address the problem of prickly hairs, future research should consider selecting Napier grass varieties that have less prickly hairs.

The main constraint in the utilization of Boma Rhodes and oats was the lack of proper storage for hay. Hay is an important investment for all livestock operations and should therefore be baled and stored in a way that maximizes the amount of available feedstuff, nutritional quality and palatability. Storing hay inside a permanent shelter is considered to be an excellent option for many livestock and commercial hay operations. Proper storage of hay prevents many of the negative effects of weathering such as loss of dry matter and reduced digestibility. More training needs to be organized so that farmers learn about site preparation, drainage, access, orientation, proximity to other farm structures such as the zero grazing unit, appropriate size, ventilation and safety of the store.

The main constraint related to the utilization of lucerne was the fact that it causes bloat when fed fresh to livestock. Farmers need more training on how and when to feed lucerne to avoid bloat which may lead to death in livestock.

\section{Dairy farmers' future plans}

About half the farmers interviewed were planning to increase feed production on their farms. The main motivation has been increased milk production and high returns from the farm. This can only be achieved if constraints raised are addressed. Key among them is unavailability of seeds/planting material. Establishment of functional seed delivery systems to match demand and supply should be given a priority. Community mechanisms of seed production should be given more emphasis. Research done in the past by Kiptot et al (2006) and Sinja et al (2004) has shown 
that farmer-to-farmer sharing of planting material is quite effective in making germplasm available. VFTs in the EADD project host demonstrations for training and bulking seed/ planting material. What is not clear is whether these demonstration plots are functional. A first step is to undertake a status update on the demonstration plots hosted by VFTs to find out whether they are indeed bulking seed/planting materials for farmers. Mechanisms of making them functional should be put in place to ensure that farmers access the seeds/planting material that they require. According to Peters et al (2003), having community-based seed production systems ensures sustainability, provides farmers with extra income and ensures that seed is available at the local level. Certified seed that is sold in agrovets may be available, however, access to farmers is limited because of the high cost. To solve this problem, seed dealers should package seed in small quantities that farmers can afford. 


\subsection{References}

Abate A, Dzowela BH and Kategile JA. 1992. Intensive animal feeding practices for optimum feed utilization. In: JA Kategile and S Mubi, eds. Future of livestock industries in East and Southern Africa. Kadoma, Zimbabwe, July 1992. Addis Ababa: International Livestock Centre for Africa, p.9-19.

Ahmed AU, Hill RV, Smith LC, Wiesmann DM, Frankenberger T. 2007. The world's most deprived: characteristics and causes of extreme poverty and hunger. 2020 vision for food, agriculture, and the environment, Discussion Paper No. 43. Washington, DC: International Food Policy Research Institute.

Ayantunde AA, Fernández-Rivera S and McCrabb G, eds. 2005. Coping with feed scarcity in smallholder livestock systems in developing countries. Kenya: Animal Sciences Group, Wageningen UR, The Netherlands; University of Reading, UK; ETH (Swiss Federal Institute of Technology), Zurich, Switzerland; and ILRI (International Livestock Research Institute), Nairobi,. p.306.

Bayer W. 1990. Napier grass - a promising fodder for smallholder livestock production in the tropics. Plant Research and Development 31:103-111.

Croppenstedt A, Goldstein M and Rosas N. 2013. Gender and agriculture inefficiencies, segregation and low productivity traps. Policy Research Working Paper, 6370. The World Bank.

Delgado C. 2003. Rising consumption of meat and milk in developing countries has created a new food revolution. Journal of Nutrition 133(11):3907S-3910S.

Elbasha E, Thornton PK and Tarawali G. 1999. An ex post economic impact assessment of planted forages in West Africa. ILRI Impact Assessment Series 2. Nairobi: ILRI, p.68.

FAO (Food and Agricultural Organization of the United Nations). 2009. The state of food and agriculture: livestock in the balance. Rome: Food and Agriculture Organization.

FAO (Food and Agricultural Organization of the United Nations). 2011. The state of food and agriculture 2010-2011. Rome: Food and Agriculture Organization.

FAO (Food and Agricultural Organization of the United Nations). 2012a. The state of food insecurity in the world. Rome: Food and Agriculture Organization.

FAO (Food and Agricultural Organization of the United Nations). 2012b. Balanced feeding for improving livestock productivity. Increase in milk production and nutrient use efficiency and decrease in methane emission. Rome: Food and Agriculture Organization.

Feder G and Umali DL. 1993. The adoption of agricultural innovations: A review. Technological Forecasting and Social Change 43:215-219.

Feder G, Just RE and Zilberman D. 1985. Adoption of agricultural innovations in developing countries: A survey. Economic Development and Cultural Change 33: 255-295. 
Franzel S. 1999. Socioeconomic factors affecting the adoption potential of improved tree fallows in Africa. Agroforestry Systems 47:305-321.

Franzel S, Wambugu C, Tuwei P and Karanja G. 2003. The adoption and scaling up of the use of fodder shrubs in central Kenya. Tropical Grasslands 37:239-250.

Hall A, Sulaiman RV and Bezkorowajnyj P. 2008. Reframing technical change: Livestock fodder scarcity revisited as innovation capacity scarcity - a conceptual framework. Systemwide Livestock Programme. International Livestock Research Institute, Nairobi, Kenya

KNBS (Kenya National Bureau of Statistics). 2010. 2009 Kenya population and housing census. Nairobi: Kenya National Bureau of Statistics.

Kiptot E. and Franzel S. 2012. Effectiveness of the farmer trainer approach in dissemination of livestock feed technologies: a survey of volunteer farmer trainers in Kenya. A research report. Nairobi: World Agroforestry Centre/EADD.

Kiptot E. 2007. Eliciting indigenous knowledge on tree fodder among Maasai pastoralists. Agriculture and Human Values 24:231-243.

Kiptot E, Franzel S, Hebinck P and Richards P. 2006. Sharing seed and knowledge: farmer to farmer dissemination of agroforestry technologies in western Kenya. Agroforestry Systems 68:167-179.

Kirui J and Franzel S. 2011. EADD Annual Report. World Agroforetry Centre, Nairobi, Kenya.

Lukuyu B, Franzel S, Ongadi P and Duncan AJ. 2011. Livestock feed resources: Current production and management practices in central and northern Rift Valley provinces of Kenya. Livestock Research for Rural Development 23:5. http://www.lrrd.org//rrd23/5/luku23112.htm

Mclntyre B, Murphy M, Cabus S and Russo S. 2010. Effective gender integration practices for agriculture: increasing women's access to resources. Series Brief 2. United States Agency for International Development.

Mekoya A, Oosting SJ, Fernandez-Rivera S, and Van der Zijpp AJ. 2008a. Multipurpose fodder trees in the Ethiopian highlands: Farmers' preference and relationship of indigenous knowledge of feed value with laboratory indicators. Agricultural Systems 96:184-194.

Mekoya A, Oosting SJ, Fernandez-Rivera S, and Van der Zijpp AJ. 2008b. Farmers' perceptions about exotic multipurpose fodder trees and constraints to their adoption. Agroforestry Systems 73:141153.

Mercer DE. 2004. Adoption of agroforestry innovations in the tropics: A review. Agroforestry Systems 204411:311-328.

Muyekho L, Mose L and Cheruiyot DT. 2003. Development and transfer of forage production technologies for smallholder dairying: case studies of participatory evaluation of species and methods of establishment in western Kenya. Tropical Grasslands 37:251-256.

Mwangi DM and Wambugu C. 2003. Adoption of forage legumes: the case of Desmodium intortum and Calliandra calothyrsus in central Kenya. Tropical Grasslands 37:227-238. 
NDDP (National Dairy Development Project). 1990. Dairy report: National Dairy Development Project, Naivasha, Kenya.

Ngigi M. 2005. The case of smallholder dairying in eastern Africa. Environment and production technology division. Working Paper No. 131. Washington, DC: International Food Policy Research Institute.

Nyaata OZ, Doward PT, Keatinge JDH and O’Neill MK. 2000. Availability and use of dry season feed resources on smallholder dairy farms in central Kenya. Agroforestry Systems 50:315-331.

Otieno K, Wekesa AN, Makale J, Owango RS, Omudeck I and Omolo J. 1999. On farm evaluation of the productivity of Tumbukiza method of Napier grass establishment and management as compared to the conventional method. National Dairy Cattle and Poultry Research Programme. Naivasha, Kenya, 7-10 June 1999. Kenya Agricultural Research Institute, Nairobi, Kenya.

Paterson RT, Karanja GM, Roothart R, Nyaata Z, Kariuki IW. 1998. A review of tree fodder production and utilization within smallholder agroforestry systems in Kenya. Agroforestry Systems 41:181-199.

Pattanayak S K, Mercer DE, Sills E and Yang JC. 2003. Taking stock of agroforestry adoption studies. Agroforestry Systems 57:173-186.Pawarda C., Gadzirayi C.T., Muriritirwa W.T. and Mwenye D. (2010). Adoption of agroforestry technologies among smallholder farmers: A case of Zimbabwe. Journal of Development and Agricultural Economics, 2 (10): 351-358.

Peters M, Lascano CE. 2003 Forage technology adoption: linking on-station research with participatory methods. Tropical Grasslands 37:197-203.

Peters M, Lascano CE, Roothaert R and de Haan NC. 2003. Linking research on forage germplasm to farmers: the pathway to increased adoption - a CIAT, ILRI and IITA perspective. Field Crops Research 84:179-188.

Roothaert RL, Franzel S. 2001. Farmers' preferences and use of local fodder trees and shrubs in Kenya. Agroforestry Systems 52:239-259.

Shelton HM, Franzel S and Peters M. 2005. Adoption of tropical legume technology around the world: analysis of success. Tropical Grassland 39:198-209.

Simmons CS, Walker RT and Wood CH. 2002. Tree planting by small producers in the tropics: a comparative study of Brazil and Panama. Agroforestry Systems 56: 89-105.

Sinja J, Karugia J, Waithaka M, Miano D, Baltenweck I, Franzel S, Nyikal R and Romney D. 2004. Adoption of fodder legumes technology through farmer-to-farmer extension approach. Uganda Journal of Agricultural Sciences 9(3):222-226.

Staal S, Chege L, Kenyanjui M, Kimari A, Lukuyu B, Njubi D, Owango M, Tanner J, Thorpe W and Wambugu M. 1998. A cross-sectional survey of Kiambu district for the identification of target groups of smallholder dairy producers. Nairobi: KARI/ILRI Collaborative Project Research Project Report, p.73.

Stotz D. 1983. Production techniques and economics of smallholder livestock production systems in Kenya. Farm management handbook of Kenya. Nairobi: MoLD, p.140. 
Thapa B, Walker DH and Sinclair F. 1997. Indigenous knowledge of the feeding value of tree fodder. Animal Feed Science and Technology 67(2): 97-114.

Thomas D and Sumberg J. 1995. A review of the evaluation and use of tropical forage legumes in subSaharan Africa. Agriculture, Ecosystems and the Environment 54:151-163.

Wambugu C, Place F and Franzel S. 2011. Research, development and scaling-up the adoption of fodder shrub innovations in East Africa. International Journal of Agricultural Sustainability 9:100-109.

Wandera JL. 1995. Pasture/Fodder Research Program. KARI, Kitale, Kenya p.48.

Wiersum KF. 1994. Farmer adoption of contour hedgerow intercropping, a case study from East Indonesia. Agroforestry Systems 27:163-182.

World Bank. 2014. Global Economic Prospects. The World Bank, Washington DC, USA. 


\section{Working Papers (2015)}

186. Agroforestry for Landscape Restoration and Livelihood Development in Central Asia http://dx.doi.org/10.5716/WP14143.PDF

187. "Projected Climate Change and Impact on Bioclimatic Conditions in the Central and South-Central Asia Region" http://dx.doi.org/10.5716/WP14144.PDF

188. Land Cover Changes, Forest Loss and Degradation in Kutai Barat, Indonesia http://dx.doi.org/10.5716/WP14145.PDF

189. The Farmer-to-Farmer Extension Approach in Malawi: A Survey of Lead Farmers. http://dx.doi.org/10.5716/WP14152.PDF

190. Evaluating indicators of land degradation and targeting agroforestry interventions in smallholder farming systems in Ethiopia. http://dx.doi.org/10.5716/WP14252.PDF

191. Land health surveillance for identifying land constraints and targeting land management options in smallholder farming systems in Western Cameroon

192. Land health surveillance in four agroecologies in Malawi

193. Cocoa Land Health Surveillance: an evidence-based approach to sustainable management of cocoa landscapes in the Nawa region, South-West Côte d'Ivoire http://dx.doi.org/10.5716/WP14255.PDF

194. Situational analysis report: Xishuangbanna autonomous Dai Prefecture, Yunnan Province, China. http://dx.doi.org/10.5716/WP14255.PDF

195. Farmer-to-farmer extension: a survey of lead farmers in Cameroon. http://dx.doi.org/10.5716/WP15009.PDF

196. From transition fuel to viable energy source Improving sustainability in the sub-Saharan charcoal sector http://dx.doi.org/10.5716/WP15011.PDF

197. Mobilizing Hybrid Knowledge for More Effective Water Governance in the Asian Highlands http://dx.doi.org/10.5716/WP15012.PDF

198. Water Governance in the Asian Highlands http://dx.doi.org/10.5716/WP15013.PDF

199. Assessing the Effectiveness of the Volunteer Farmer Trainer Approach in Dissemination of Livestock Feed Technologies in Kenya vis-à-vis other Information Sources http://dx.doi.org/10.5716/WP15022.PDF

200. The rooted pedon in a dynamic multifunctional landscape: Soil science at the World Agroforestry Centre http://dx.doi.org/10.5716/WP15023.PDF

201. Characterising agro-ecological zones with local knowledge. Case study: Huong Khe district, Ha Tinh, Viet Nam http://dx.doi.org/10.5716/WP15050.PDF

202. Looking back to look ahead: Insight into the effectiveness and efficiency of selected advisory approaches in the dissemination of agricultural technologies indicative of Conservation Agriculture with Trees in Machakos County, Kenya. http://dx.doi.org/10.5716/WP15065.PDF

203. Pro-poor Biocarbon Projects in Eastern Africa Economic and Institutional Lessons http://dx.doi.org/10.5716/WP15022.PDF

204. Projected climate change impacts on climatic suitability and geographical distribution of banana and coffee plantations in Nepal. http://dx.doi.org/10.5716/WP15294.PDF

205. Agroforestry and Forestry in Sulawesi series: Smallholders' coffee production and marketing in Indonesia. A case study of two villages in South Sulawesi Province. http://dx.doi.org/10.5716/WP15690.PDF

206. Mobile phone ownership and use of short message service by farmer trainers: a case study of Olkalou and Kaptumo in Kenya http://dx.doi.org/10.5716/WP15691.PDF

207. Associating multivariate climatic descriptors with cereal yields: a case study of Southern Burkina Faso http://dx.doi.org/10.5716/WP15273.PDF 
The World Agroforestry Centre is an autonomous, non-profit research organization whose vision is a rural transformation in the developing world as smallholder households increase their use of trees in agricultural landscapes to improve food security, nutrition, income, health, shelter, social cohesion, energy resources and environmental sustainability. The Centre generates science-based knowledge about the diverse roles that trees play in agricultural landscapes, and uses its research to advance policies and practices, and their implementation that benefit the poor and the environment. It aims to ensure that all this is achieved by enhancing the quality of its science work, increasing operational efficiency, building and maintaining strong partnerships, accelerating the use and impact of its research, and promoting greater cohesion, interdependence and alignment within the organization.

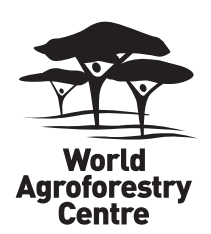

United Nations Avenue, Gigiri • PO Box 30677 • Nairobi, 00100 • Kenya Telephone: +254 207224000 or via USA +1 6508336645 Fax: +254207224001 or via USA +1 6508336646 Email: worldagroforestry@cgiar.org •www.worldagroforestry.org 